INTERNATIONAL MONETARY FUND
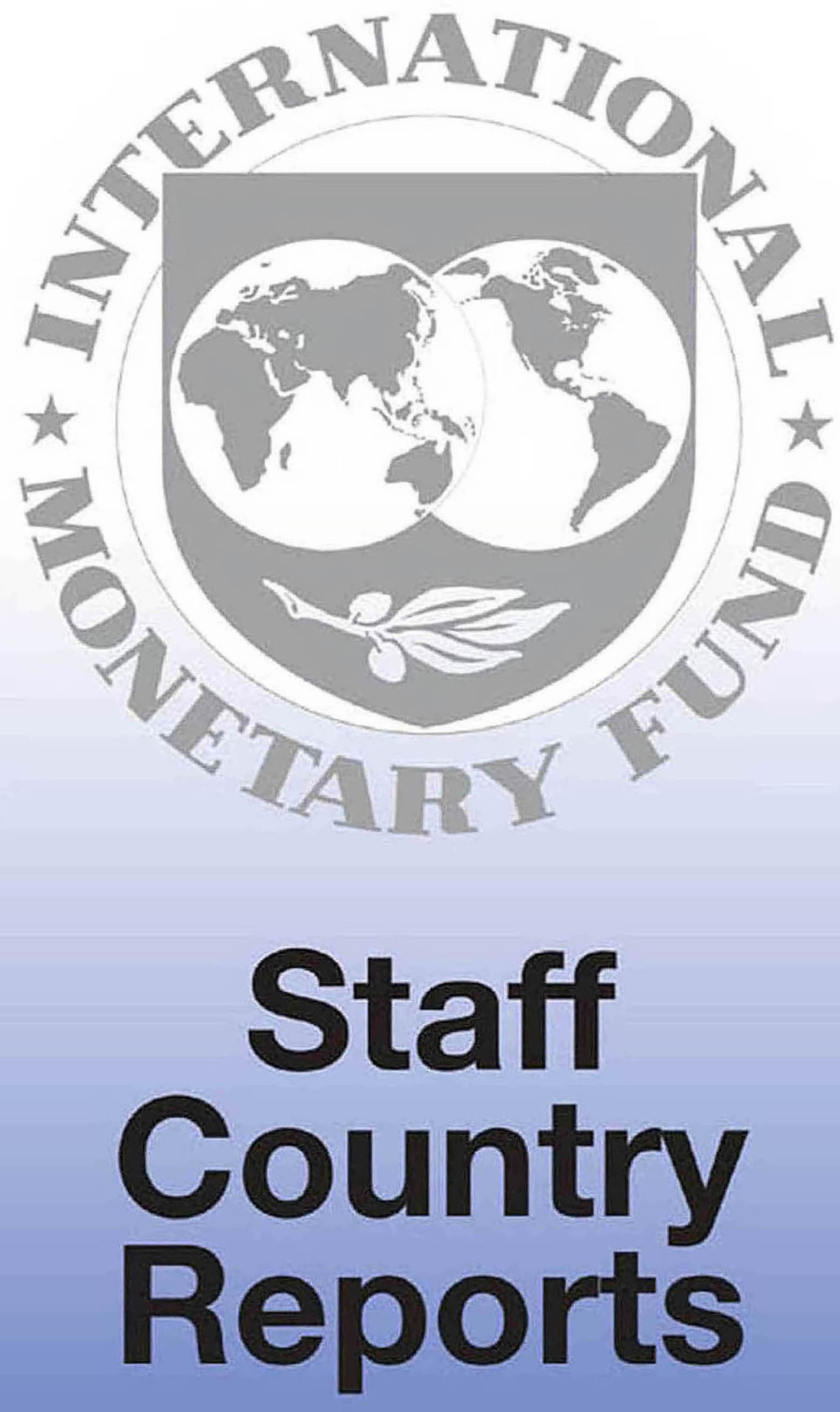


\section{Belgium: Financial System Stability Assessment}

This paper was prepared based on the information available at the time it was completed on April 25, 2013. The views expressed in this document are those of the staff team and do not necessarily reflect the views of the government of Belgium or the Executive Board of the IMF.

The policy of publication of staff reports and other documents by the IMF allows for the deletion of market-sensitive information.

Copies of this report are available to the public from

International Monetary Fund $\bullet$ Publication Services

700 19th Street, N.W. • Washington, D.C. 20431

Telephone: (202) 623-7430 • Telefax: (202) 623-7201

E-mail: publications@imf.org • Internet: http://www.imf.org

\section{International Monetary Fund \\ Washington, D.C.}




\section{INTERNATIONAL MONETARY FUND}

\section{BELGIUM}

April 25, 2013

\section{FINANCIAL SYSTEM STABILITY ASSESSMENT}

\section{EXECUTIVE SUMMARY}

Much has been done to address the fallout from the financial crisis in Belgium, but important vulnerabilities linger. The impact of the crisis on Belgium was substantial, resulting in a sharp output contraction, wide-spread instability in financial markets, and an abrupt deterioration in banks' financial positions requiring substantial state support. Following a determined response by authorities, a radically changed and downsized financial system emerged. Its ongoing transformation involves significant downside risks, and the policy momentum should be sustained to preserve stability.

\section{Low profitability and macroeconomic prospects remain a source of vulnerability.}

The growth outlook for Belgium is weak, with risks skewed to the downside. For banks, structurally high costs are compounded by the diminishing earning capacity and the impact of regulatory reforms, while a downturn in housing prices would further exacerbate capital pressures. As firms refocus on the domestic market and core activities, increased competition puts pressure on profits. Prolonged low interest rates will create vulnerabilities for banks and life insurers. In combination with legacy portfolios, this might call into question the viability of business models for some firms in both sectors necessitating close supervisory monitoring.

The links between banks, insurers, and Belgian sovereign have intensified posing additional risks. Market confidence remains fragile in the euro area and domestic political risks will persist as 2014 elections approach. A widening of the sovereign spread would raise funding costs and worsen capital and liquidity positions of banks and insurers in an environment of constrained profitability. The large public debt limits the government's capacity for remedial measures making it important to guard against inaction and supervisory forbearance.

These vulnerabilities are confirmed by the stress tests. Banks' initial capital levels are solid in aggregate, but several banks would experience significant deterioration of profitability under stress. Given the forthcoming additional capital requirements, capital pressures could emerge in the medium term. Bank capital buffers should thus be strengthened. Credit risk appears limited, owing to historically low loss rates, but potential vulnerabilities from real estate overvaluation warrant a closer examination. 
Insurers remain sufficiently capitalized under the current solvency regime, while the picture under market-consistent valuation calls for supervisors to remain vigilant and advance contingency planning under the new recovery and resolution framework.

The new regulatory structure is functioning well, but remaining concerns should be addressed. Compliance with international standards for regulation and supervision of banks and insurers is generally high. Good risk-based practices are employed, particularly for large groups. A proportionate supervisory approach should be espoused also for smaller institutions. The decision to adopt elements of Solvency II ahead of schedule is welcome. However, strengthening the conduct of business regime for insurers and intermediaries as well as increasing supervisory resources remain a priority. The NBB and FSMA show strong commitment to home-host cooperation. Operational cooperation framework between the NBB and FSMA needs to be finalized.

\section{Financial stability risks underscore the need for a more intensive and intrusive} supervision. Promoting a supervisory culture in which the "will to act" is both expected and rewarded will be key to managing the complexities still present in the rapidly transforming system. A more uniform approach to the identification and assessment of cross-sectoral risks is necessary to improve conglomerates supervision, as well as a more consistent application of group-wide governance requirements.

\section{Effective regulation, supervision, and oversight of Euroclear Bank-a systemically} important FMI-is in place. The authorities should work more closely with the Luxembourg counterparts responsible for Clearstream Bank Luxembourg, to ensure a level playing field in risk management practices. Broadening this cooperation, with the involvement of the ECB, would allow the authorities to coordinate recommendations and to seek their parallel implementation in both entities.

\section{While bank failures have been handled decisively, the resolution toolkit remains} work in progress. Legislation for dealing with systemic situations introduced in 2010 brought improvements. Progress has been made in the area of recovery planning by domestic systemically important banks (D-SIBs) and systemically relevant infrastructures. However, robust and flexible resolution framework is still needed, as well as a comprehensive reform of the deposit insurance.

This assessment has been performed against the backdrop of rapidly evolving EUwide landscape. Even though bank supervision will shift to the $E C B$, operational responsibilities at a local level will likely remain important both in transition and in the steady state. Oversight of conglomerates will become more challenging, and close coordination with the ECB will be needed. Maintaining momentum in improving supervisory practices in Belgium therefore remains important.

High priority recommendations are shown in Table 1. 
Table 1. Belgium: FSAP Update-High Priority Recommendations

\begin{tabular}{|c|c|}
\hline Policy Action & Timing \\
\hline \multicolumn{2}{|l|}{ Overall financial stability oversight } \\
\hline Formalize procedures and improve information exchange between the NBB and FSMA. & Immediate \\
\hline Make stress testing a routine tool within the macro-financial policy and surveillance framework. & Short term \\
\hline Enhance further stress testing of insurers using a market consistent valuation framework. & Short term \\
\hline $\begin{array}{l}\text { Complete the ongoing business model reviews for both banks and insurance companies and } \\
\text { develop a strategy for both sectors over the medium term. }\end{array}$ & Short term \\
\hline $\begin{array}{l}\text { Develop an explicit conglomerates supervision framework and ensure consistent application of } \\
\text { governance requirements across financial conglomerates. }\end{array}$ & Medium term \\
\hline $\begin{array}{l}\text { Designate the NBB as the macroprudential authority, ensuring a regular dialogue with FSMA } \\
\text { and MOF on macroprudential and financial stability matters. }\end{array}$ & Medium term \\
\hline \multicolumn{2}{|l|}{ Banking regulation and supervision } \\
\hline $\begin{array}{l}\text { Review supervisory processes and calibrate intensity and resource allocation based on } \\
\text { institutions' risk profiles, particularly for smaller institutions. }\end{array}$ & Short term \\
\hline $\begin{array}{l}\text { Embed engagement with bank and insurance boards in the supervisory process in a systematic } \\
\text { way. }\end{array}$ & Medium term \\
\hline Empower the NBB to pre-approve a major acquisition by a credit institution. & Medium term \\
\hline $\begin{array}{l}\text { Maintain current liquidity regulatory regime until the Basel III Liquidity Coverage Ratio (LCR) is } \\
\text { fully adopted and phased in at the European level. }\end{array}$ & Ongoing \\
\hline \multicolumn{2}{|l|}{ Insurance regulation and supervision } \\
\hline $\begin{array}{l}\text { Formulate a baseline prudential supervisory program for insurers and risk-based conduct-of- } \\
\text { business supervision of insurers and intermediaries. }\end{array}$ & Short term \\
\hline $\begin{array}{l}\text { Align findings of insurance tress testing with contingency planning in the context of the } \\
\text { recovery and resolution framework. }\end{array}$ & Short term \\
\hline Implement elements of Solvency II, including an Own Risk and Solvency Assessment regime. & Medium term \\
\hline $\begin{array}{l}\text { Empower the NBB to take immediate recovery measures notwithstanding an appeal by an } \\
\text { insurer. }\end{array}$ & Medium term \\
\hline \multicolumn{2}{|l|}{ Securities markets supervision } \\
\hline $\begin{array}{l}\text { Establish an Emerging Risk Committee at the FSMA and formalize framework for detecting and } \\
\text { monitoring emerging risks. }\end{array}$ & Medium term \\
\hline \multicolumn{2}{|l|}{ Crisis management and resolution framework } \\
\hline $\begin{array}{l}\text { Formalize domestic coordination arrangements for the financial safety net participants via a } \\
\text { crisis management MOU and the establishment of a cross-institutional coordination group. }\end{array}$ & Short term \\
\hline Request recovery and resolution plans (RRPs) for all domestic systemically important firms. & Short term \\
\hline Grant NBB an explicit mandate as the resolution authority. & Medium term \\
\hline $\begin{array}{l}\text { Improve the bank resolution toolkit by reducing ex ante procedural requirements, extending } \\
\text { the framework to all banks and enhancing powers for special inspectors. }\end{array}$ & Medium term \\
\hline Revamp the deposit guarantee scheme, establish ex ante fund and depositor preference. & Medium term \\
\hline
\end{tabular}




\section{Approved By \\ Christopher Towe \\ Reza Moghadam \\ Prepared By \\ Michaela Erbenová \\ Jennifer Elliott}

An International Monetary Fund (IMF) mission visited Brussels in November 2012 and January 2013 to update the Financial Sector Assessment Program (FSAP) for Belgium, conducted in 2004 and 2005 and finalized in 2006. The findings were further discussed with the authorities during the Article IV consultation mission in March 2013. The mission prepared several technical notes that underpin the discussion in this document.

The mission held discussions with senior officials and staff of the National Bank of Belgium (NBB), the Financial Services and Markets Authority (FSMA), the Ministry of Finance (MOF), Ministers of Finance and Budget for the Brussels, Flanders and Walloon Regions. The mission also met representatives of academia and the private sector. The team would like to express its gratitude to the Belgian authorities for the excellent engagement and cooperation.

The team was comprised of Michaela Erbenová (mission chief), Jennifer Elliott (deputy mission chief), Su Hoong Chang, Oana Nedelescu, Sylwia Nowak, Marco Pinon, Katharine Seal, Mario Tamez, Constant Verkoren, and Christopher Wilson (all IMF); and Steven Bardy (Australia Securities and Investments Commission), Andreas Jobst (Bermuda Monetary Authority), Philipp Keller (formerly Switzerland Financial Markets Authority, consultant), and Alexandria Luk (USA Office of the Comptroller of the Currency). Sofiya Avramova and Suchitra Kumarapathy provided research assistance from Washington.

FSAPs assess the stability of the financial system as a whole and not that of individual institutions. They are intended to help countries identify key sources of systemic risk in the financial sector and implement policies to enhance its resilience to macroeconomic shocks and cross-border contagion. FSAPs do not cover risks that are specific to individual institutions such as asset quality, operational or legal risks, or fraud. 


\section{CONTENTS}

GLOSSARY

INTRODUCTION AND BACKGROUND

A. Macroeconomic and Financial Sector Developments

B. Household and Corporate Sector Developments

C. Implementation of 2006 FSAP Recommendations

12

SOUNDNESS OF THE FINANCIAL SYSTEM AND POTENTIAL RISKS

A. Financial Crisis and Policy Response__ $\underline{12}$

B. Vulnerabilities Analysis __ $\underline{13}$

C. Bank Stress Testing __ 17

D. Insurance Stress Testing___ 21

FINANCIAL STABILITY FRAMEWORK __ $\underline{24}$

A. Banking Supervision _ $\underline{25}$

B. Insurance Supervision — $\underline{29}$

C. Conglomerates Supervision __ $\underline{29}$

D. Securities Markets and Regulation ___ $\underline{30}$

E. Soundness and Oversight of Market Infrastructures___ $\underline{31}$

F. Crisis Management and Safety Nets ___ 32

G. Anti-Money Laundering and Combating the Financing of Terrorism (AML/CFT)__ $\underline{33}$

BASEL CORE PRINCIPLES FOR EFFECTIVE BANKING SUPERVISION__

A. Background__ $\underline{74}$

B. NBB Approach to Supervision __ $\underline{74}$

C. Assessment Challenges___ $\underline{75}$

D. Preconditions for Effective Supervision___

E. Main Findings__ $\underline{75}$

F. Authorities' Response to the Assessment___ $\underline{85}$

INTERNATIONAL ASSOCIATION OF INSURANCE SUPERVISORS (IAIS) INSURANCE CORE PRINCIPLES__ $\underline{90}$

A. Background__ $\underline{90}$

B. Preconditions for Effective Securities Regulation ___ $\underline{90}$

C. Main Findings _ـ $\underline{91}$ 


\section{BOXES}

1. Outward Spillovers from Belgium Financial Sector $\underline{15}$

2. Network Analysis of Spillover Risk for the Belgian Banking System $\underline{16}$

3. The Impact of the Banking Union on Belgium $\underline{28}$

FIGURES

1. Structural Features of the Financial Sector $\underline{34}$

2. Economic Developments $\underline{35}$

3. Nonfinancial Sector Developments___ $\underline{36}$

4. Financial Market Indicators___

5. Banking Sector Developments___ $\underline{38}$

6. International Exposures of Belgian Banks, 2007-12_ $\underline{39}$

7. Insurance Financial Soundness Indicators __ $\underline{40}$

8. Macroeconomic Assumptions Under Different Stress Test Scenarios___

9. Solvency Stress Test Results_CET1 Hurdle Rate __

10. Liquidity Indicators and Stress Test Results___

\section{TABLES}

1. Belgium: FSAP Update_-High Priority Recommendations___ $\underline{3}$

2. Baseline-Selected Economic Indicators, 2009-17___ 44

3. Structure of the Financial Sector___ $\underline{45}$

4. Financial Sector State Support (2012)___ 46

5. Financial Soundness Indicators for the Banking Sector ___ 47

\section{APPENDICES}

I. Belgian Covered Bonds and Financial Stability Considerations___ $\underline{48}$

II. Main Recommendations of the 2006 FSAP ___ $\underline{53}$

III. Crisis Intervention and Restructuring Measures__ $\underline{56}$

IV. Risk Assessment Matrix __ $\underline{59}$

V. Overview of Stress Tests for Banks __ $\underline{61}$

\section{ANNEX}

I. Report on the Observance of Standards and Codes-Summary Assessments 


\section{Glossary}

AML/CFT

Basel III

BCP

$\mathrm{BU}$

CET1

COB

CPSS

CRD IV

ECB

EIOPA

EU

FATF

FC

FMI

FSAP

FSMA

IAIS

ICAAP

ICP

IMF

IOSCO

LCR

LTV

MCR

$\mathrm{MCV}$

MiFID 2

MOF

$\mathrm{MOU}$

MFHC

NBB

$N P L$

NSFR

RRP

RWA

SCR

Solvency I (II)

SSM

SWIFT

TD
Anti-Money Laundering/Combating the Financing of Terrorism

Revised regulatory standard on capital and liquidity for banks developed by the Basel Committee on Banking Supervision Basel Core Principles for Effective Banking Supervision

Bottom-up (stress test)

Common Equity Tier 1

Conduct of business (regulation or supervision)

Committee on Payment and Settlement Systems

Capital Requirements Directive, Fourth Iteration

European Central Bank

European Insurance and Occupational Pensions Authority

European Union

Financial Action Task Force

Financial Conglomerate

Financial Market Infrastructure

Financial Sector Assessment Program

Financial Services and Markets Authority

International Association of Insurance Supervisors

Internal Capital Adequacy Assessment Process

Insurance Core Principles

International Monetary Fund

International Organization of Securities Commissions

Liquidity Coverage Ratio

Loan-to-value (ratio)

Minimum Capital Requirement

Market-consistent valuation (in insurance stress test)

Markets in Financial Instruments Directive 2

Ministry of Finance

Memorandum of Understanding

Mixed Financial Holding Company

National Bank of Belgium

Nonperforming Loan

Net Stable Funding Ratio

Recovery and Resolution Plan

Risk-weighted assets

Solvency Capital Requirement

Current (forthcoming) EU prudential framework for insurers

Single supervisory mechanism in the EU

Society for Worldwide Interbank Financial Telecommunications

Top-down (stress test) 


\section{INTRODUCTION AND BACKGROUND}

\section{A. Macroeconomic and Financial Sector Developments}

1. The Belgian financial system is relatively large, concentrated, and interconnected with the rest of the world (Figure 1). The banking system is dominated by four banking groups representing almost three-fourths of consolidated system assets. System assets grew rapidly from 384 percent of GDP in 2000 to 470 percent of GDP in 2007, with growth largely driven by an expansion of investment banking activities financed through the surplus of domestic retail deposits and wholesale funding. Assets of foreign-owned banks account for more than half of the sector. The insurance sector is embedded in the predominant bancassurance model and dominated by a few conglomerates.

2. The $\mathbf{2 0 0 8}$ global financial crisis had a major impact on the Belgian financial sector. The top three Belgian conglomerates were hit hard as funding dried up and capital positions were depleted by massive losses on structured financial products, large write-offs, and provisions. The state provided capital injections and extensive funding and asset guarantees to the three largest banks and several insurers. Since 2008, banks have shed investment banking and asset management activities and shifted focus to a more "traditional" banking model, focused primarily on the domestic market. An initial deleveraging reduced the size of the banking sector to 310 percent of GDP in mid2012, with a second wave of deleveraging currently under way, albeit at a slower pace. Cross-border claims fell from 300 percent of GDP in 2008 to 58 percent of GDP in mid-2012. The largest remaining exposures are to the Czech Republic, France, Ireland, the United Kingdom, and the United States.

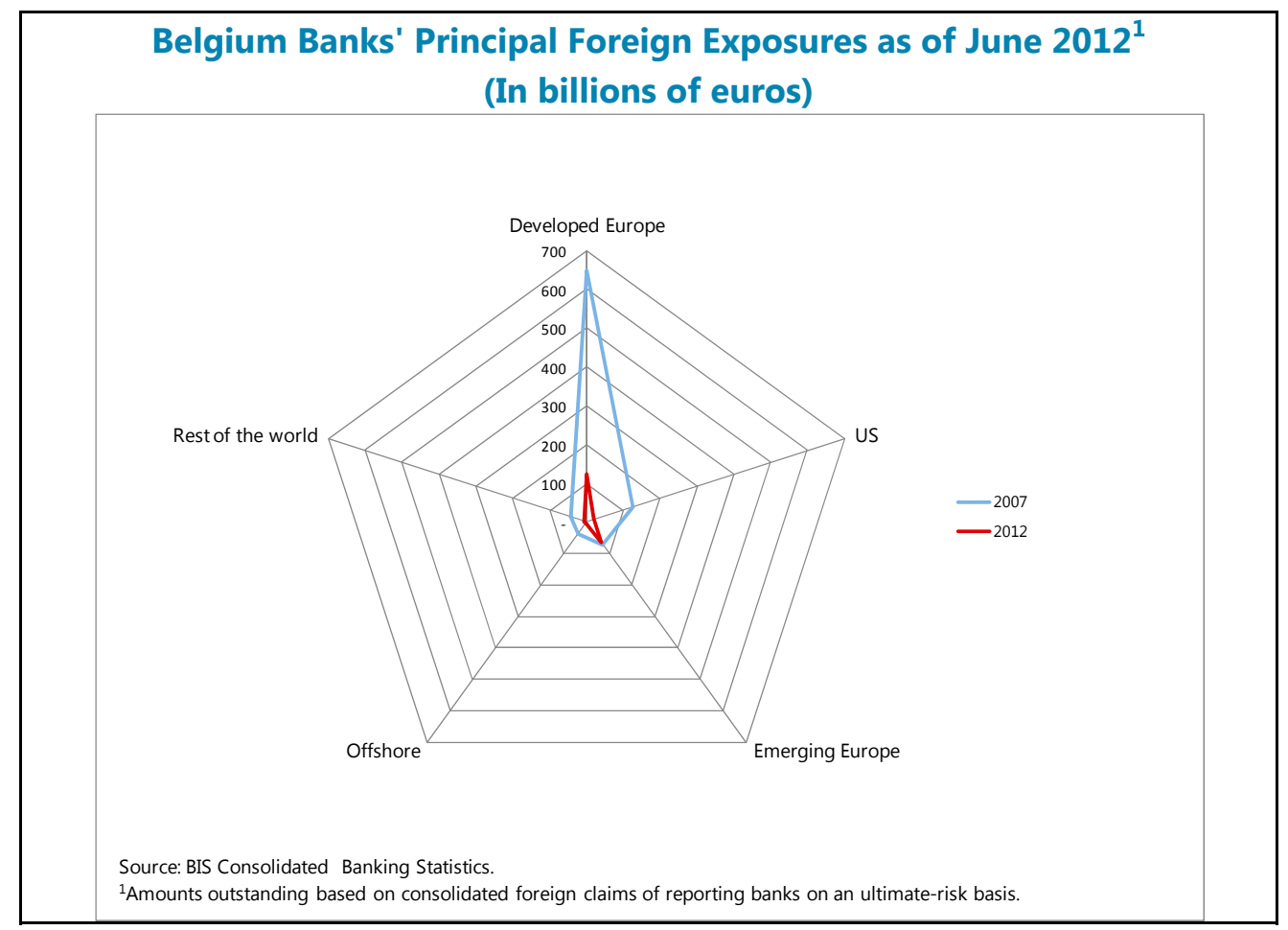




\section{Following a short-lived recovery, growth has slowed significantly since the start of} 2012 and is expected to stagnate through 2013 (Figure 2, Table 2). In addition to weak external demand in the European Union (the main trading partner), domestic demand is deteriorating, reflecting higher uncertainty, depressed consumer and business sentiment, and fiscal consolidation. The unemployment rate has begun to edge upward. The general government deficit widened to 3.9 percent of GDP in 2012 and the dynamics of the debt-to-GDP ratio remains tenuous in light of low growth prospects. The government has initiated labor market and pension reforms aimed at boosting the employment rate and potential growth, but implementation is challenging and Belgium's competitiveness continues to fall.

4. Bank-sovereign linkages have intensified due to the crisis. The total exposure of the banking sector to the Belgian government (including exposure to local authorities) has increased substantially since 2008 and stood at 11 percent of banking sector assets in mid-2012, while the contingent fiscal liabilities stemming from the state aid to Dexia, Fortis, and KBC are estimated to have reached 18 percent of GDP. With substantial exposures to the Belgian government and limited fiscal headroom remaining, fiscal consolidation is critical to avoiding a weakening of market confidence and increasing funding costs.

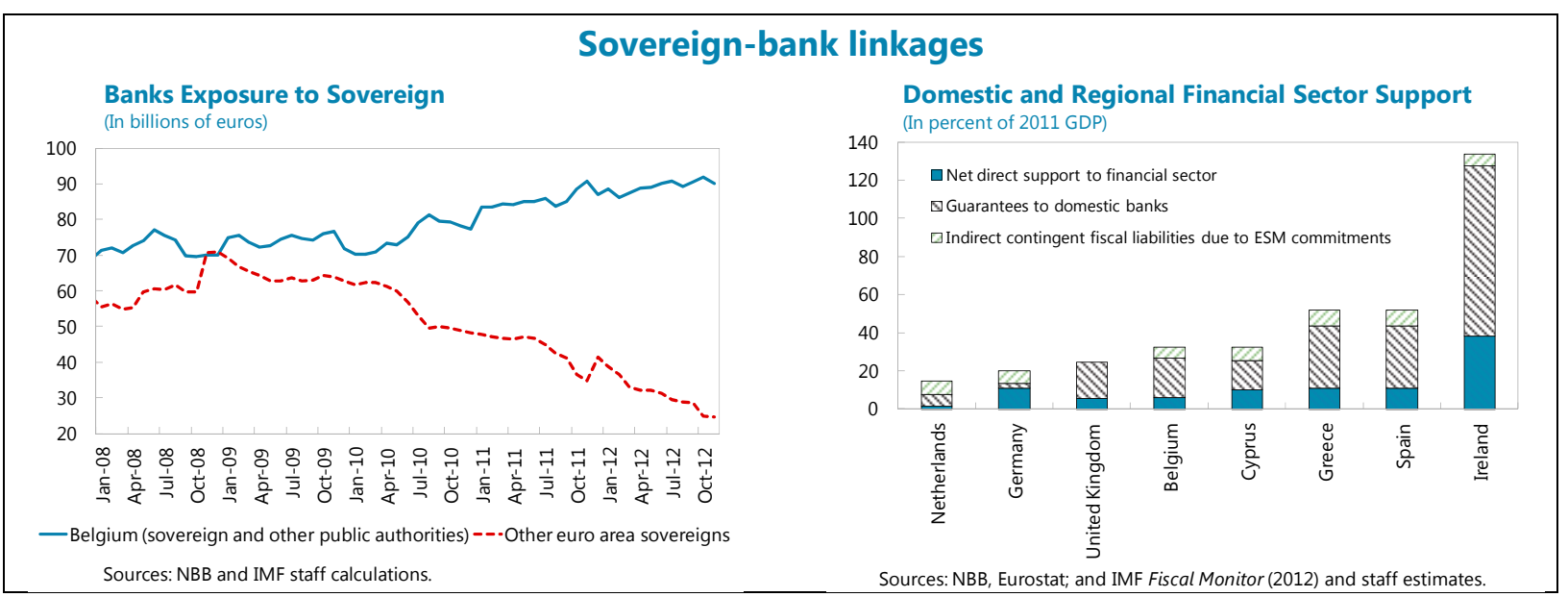

\section{The Belgian insurance industry is mature and dominated by a few financial}

conglomerates. It is a one-fifth the size of the banking sector, accounting for 69 percent of GDP at end-2011 (i.e., €255 billion). The top five life insurers accounted for 71 percent of the total assets, while the top five nonlife insurers held 58 percent of assets in 2011 . The industry is dominated by composite insurers that conduct both life and nonlife insurance operations. Nine insurance groups derived, on average, more than 90 percent of their premiums from domestic operations in 2011, while the largest group wrote more than a third of premiums abroad.

\section{The asset management industry comprises both UCIT and non-UCIT vehicles. Total} assets under management in UCITs stood at 80 percent of GDP (or €293 billion) at mid-2012 and only 4 percent of European market share, with another $€ 250$ billion (68 percent of GDP) in assets under management in non-UCIT vehicles (Table 3). Privately managed pension funds remain small. 
Structure of the Belgian Financial System Assets, 2011

(In percent of total consolidated financial system assets)

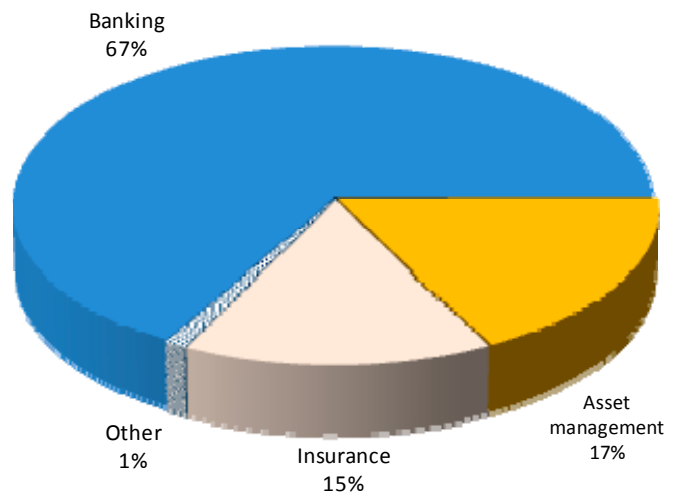

Source: NBB, FSMA, and IMF staff calculations.

7. Financial market infrastructure is large and cross-border in focus. Euroclear, the largest clearing and settlement system in Europe (with a transaction volume of $€ 580.6$ trillion in 2011), is located in Belgium and supervised by the NBB as the lead regulator. ${ }^{1}$ With $€ 18$ trillion worth of securities held in custody, Bank of New York Mellon SA/NV - the country's sixth largest bank-is a global custodian and asset manager that centers its European business in Brussels. The NBB also coordinates the oversight of the Society for Worldwide Interbank Financial Telecommunications (SWIFT), a systemically important global financial messaging system.

\section{A new framework for covered bonds was put in place in 2012 (Appendix I) and two} large institutions issued bonds shortly after the law came into place with strong demand. ${ }^{2}$ The framework provides investors in covered bonds with a range of protections. The framework provides for dedicated on balance sheet structures without the use of separate issuing vehicles, while ensuring a dual recourse to the cover pool and the issuer (i.e., other assets of the issuing bank). Issuance limits mitigate the risk that reliance on covered bonds for funding could, over time, weaken issuers' resilience in a crisis or their resolvability.

\footnotetext{
${ }^{1}$ The oversight and risk management of Euroclear Bank have been assessed under the Principles for Financial Markets Infrastructure assessment undertaken by the EU FSAP (see European Union Financial Sector Assessment Report http://www.imf.org/external/pubs/ft/scr/2013/cr1375.pdf). Results of that assessment relevant for Belgium are incorporated in this document.

2 The publication of two Royal decrees on October 18, 2012, following the enactment of a covered bond law in August 2012, allowed Belgian credit institutions to issue covered bonds by end-2012.
} 


\section{B. Household and Corporate Sector Developments}

\section{Real estate prices in Belgium have continued to increase prompting concerns about} sustainability (Figure 3). Prices have more than doubled in the past decade, and are up by 90 percent in real terms since 2000. Price appreciation has resumed, even in the wake of the recent crisis, outpacing increases in other advanced countries. Various estimates suggest the Belgian housing market is overvalued by 5-20 percent. Nevertheless, prices remain relatively low in Belgium compared with much of the rest of Europe and the supply of properties is limited. The growing demand for housing seems to reflect an immigration-driven increase in the population accompanied by a decline in average household size. Most properties are owner-occupied and real estate turnover is discouraged through high transaction costs.

\section{Households' debt and vulnerability to interest rate changes have increased, and the NBB has called for a tightening of mortgage lending standards. At 90 percent of disposable} income, household indebtedness is relatively low compared to other advanced economies, while households' gross and net wealth is amongst the highest in the EU. On average mortgage debt service has remained affordable and roughly constant in the last few years, but about 20 percent of borrowers need to use 50 percent of their disposable income or more to service their mortgage. The share of variable interest rate debt in total household debt has also risen, especially for low-income households, increasing vulnerability to high and widespread unemployment or a disposable income shock. ${ }^{3}$ Build up of risk in this area should be closely monitored, and authorities should weigh merits of activating specific macroprudential tools if needed.

\section{Having entered the recession from a strong financial position, nonfinancial} corporations now face competitiveness headwinds. In 2008, profits fell sharply, particularly for sectors exposed to global trade. After a short-lived recovery of corporate financial positions in 2010 and 2011, corporate bankruptcies rates increased significantly in the fall of 2012, with business startups declining by 21 percent year-on-year. Nonfinancial corporate debt on a consolidated basis (i.e., excluding intra-company lending) stood at 87 percent of GDP in Q3 2012, with banks 'exposure to the sector stable at about a third of total loans in 2007-12. ${ }^{4}$ Overall, sufficient buffers in the corporate sector helped prevent a severe retrenchment of investment and employment throughout the downturn, but a loss of cost competitiveness will constrain economic rebound. ${ }^{5}$

\footnotetext{
${ }^{3}$ Based on the 2012 NBB Financial Stability Report, loan-to-value (LTV) ratios for a portion of the recently originated mortgages to low-income households have been close to 100 percent (vs. the average of about 65 percent) while on aggregate 40 percent of the outstanding stock of mortgages have LTVs above 80 percent.

${ }^{4}$ The difference between the level of non-consolidated and consolidated debt of nonfinancial corporations is due to a large level of intra-company lending, which is mainly intragroup and is mostly attributed to the location of corporate treasury functions of multinational companies in Belgium.

${ }^{5}$ Since 2011, Belgium has fallen behind Germany, France, and the Netherlands in terms of export performance, as unit labor costs have grown faster than those of its neighbors, pushed by sticky inflation and wage indexation.
} 


\section{Implementation of 2006 FSAP Recommendations}

12. The authorities have made progress in addressing the recommendations of the 2006 FSAP (Appendix II) but many recommendations in the area of conglomerate supervision and governance remain relevant. The new institutional model is a work in progress and better communication and coordination between supervisory institutions is needed. Improvements are evident in the intensity of banking supervision and the adoption of analytical tools to support system-wide monitoring, including the introduction of an intensive Internal Capital Adequacy Assessment Process (ICAAP) process for determining Pillar II capital requirements, liquidity stress testing for the banking sector, and introduction of macro-financial risk dashboard to monitor systemic and emerging risk. Funding and risk management standards are being improved. Supervisory tools for monitoring group-wide risks need to be upgraded. The crisis management framework, while updated for handling systemic firms, is in need of a further upgrade owing in part to EU-wide developments.

13. Insurance supervision has been significantly strengthened although further work is needed, particularly, in strengthening the solvency framework. Both bank and insurance supervisory frameworks integrate vertical analyses of individual insurers with horizontal review of the sector. The adoption of the new institutional architecture has allowed the FSMA to focus solely on market and business conduct and the adoption of EU directives in the interim has addressed many of the recommendations for the securities sector. The FSMA's plan to adopt a risk-based approach to conduct supervision must be adequately resourced. Pension regulation and supervision has been strengthened. While pension funds remain the remit of the FSMA, there is currently a debate as to whether this should be the responsibility of the NBB.

\section{SOUNDNESS OF THE FINANCIAL SYSTEM AND POTENTIAL RISKS}

\section{A. Financial Crisis and Policy Response}

14. The authorities' response to the $\mathbf{2 0 0 8}$ crisis was prompt and forceful, but potential spillovers and execution risks remain (Table 4, Appendix III). Capital injections and government guarantees, combined with market pressure, set a stage for major restructuring of the Belgian financial sector. Crisis intervention has proved stabilizing (Figure 4). The intervened institutions are in different stages of recovery and deleveraging is well advanced across the sector. Most banks have successfully returned to funding markets and in some cases they have been able to raise new equity. Nevertheless, several groups remain reliant on public support and difficult market conditions could challenge their ability to maintain the planned pace of deleveraging through further asset disposals. Unwinding the state support will take time, and success ultimately depends on restoring financial stability across the euro area.

15. The dismantling of the Dexia Group is a long-term and complex process requiring continued vigilance by authorities. The restructuring entails substantial operational and financial 
implications for the entities of the former group, and utilizes significant state guarantees to secure the financing of the legacy assets. Recent steps taken by the Belgian and French governments were important to stabilize the group and have reduced the burden on the Belgian state. ${ }^{6}$ The execution of the restructuring plan will require intensive supervisory and government oversight, as well as close coordination with the French authorities, to prevent contagion and minimize future fiscal costs.

\section{B. Vulnerabilities Analysis ${ }^{7}$}

16. Domestic economic challenges remain sources of continued uncertainty as the banking sector consolidates (Figure 5). Banks have struggled for profitability since the crisis, and structural costs remain high. ${ }^{8}$ As the restructuring of the sector comes to an end, further efficiency gains might be difficult to achieve due to the natural wage drift and growth of operating expenses. Interest margins are likely to come under pressure in response to greater reliance on more costly term deposits and longer maturity bonds (in lieu of wholesale funding), as well as limited pricing power in an increasingly saturated domestic lending market with sovereign interest rate-indexed lending rates adjusting downward. In turn, weaker earnings capacity and lower investment returns will constrain banks' ability to maintain existing capital buffers under the forthcoming new capital requirements and replenish capital in case of renewed macro-financial shocks.

\section{A wide and stable deposit base and the strategic re-orientation of the banking sector} toward the domestic market helped avoid a decline in credit supply. A 25 percent fall in aggregate bank assets since 2007-owing to a drop of exposures outside Belgium by over 40 percent-has increased the banks' focus on their home markets, where the overall level of impairments has remained relatively modest so far. However, a weak economic environment and higher unemployment will affect debt servicing capacity and affordability, which might lead to deterioration in asset quality over the medium term. Faced with excess liquidity from a high level of domestic savings, banks have incentive to increase investment yields and intragroup funding

\footnotetext{
${ }^{6}$ To accommodate losses from the continuing divestments of Dexia subsidiaries, the Belgian and French governments injected additional capital of $€ 5.5$ billion into Dexia in December 2012 and reduced the funding guarantees ceiling to $€ 85$ billion. The European Commission has approved sovereign funding guarantees for Dexia and its restructuring plan on December 28, 2012. Belgium's recapitalization of Dexia amounts to 2.3 percent of GDP while the contingent liabilities arising from the funding guarantees add up to 14 percent of GDP.

${ }^{7}$ Analysis excludes Dexia Group (operating according to the restructuring plan approved by the European Commission and not engaged in any new lending or deposit collection in Belgium), foreign branches, Euroclear Bank (clearing and settlement system) and Bank of NY Mellon SA/NV (custodian bank). Belfius bank is included.

${ }^{8}$ The general administrative spending relative to operating profit declined on aggregate from a peak of 86 percent in 2008 to 67 percent at end-2011 on aggregate, resulting in a transient stabilization of business margins. The average cost-to-income ratio of large EU banks was 62 percent during the first half of 2012 according to ECB statistics. See the Statistical Data Warehouse of the ECB at http://sdw.ecb.europa.eu.
} 
arrangements within conglomerate structures. This underscores the importance of robust intragroup exposure reporting and conglomerate supervision.

\section{Aggregate capitalization of the banking system compares favorably to other major} international banking systems. Supervisory action, deleveraging, and improved risk management following the crisis have pushed banks toward stronger capital positions and enhanced short-term liquidity. Tier 1 capital for the Belgian banking system has risen from 11.5 percent of risk-weighted assets in 2008 to 13.4 percent mid-2012 (Table 5). Leverage ratios, with regulatory capital at 6.2 percent of total assets for the system (and 6.1 percent for the group of six largest banks), compare favorably to European peers.

19. Liquidity and funding pressures have abated for the time being. Banks have made material progress in reducing their dependence on wholesale funding and collateralized central bank repos, and liquidity buffers are comfortable in most large banks. Stricter liquidity regulation by the NBB introduced in 2011 has been conducive to greater focus on liquidity risk management. At the same time, measures taken by the Eurosystem to support the liquidity position of euro area banks eased investor concerns but have led to an increase in asset encumbrance in several large banks. Access to wholesale funding could become more difficult should market's perception of sovereign risk deteriorate.

\section{Banks' exposures to vulnerable euro area sovereigns have declined significantly since} the onset of the crisis in Europe (Figure 6). Both sovereign and private claims on Greece, Portugal, Spain, and Italy have declined and have been replaced with exposures to the Belgian sovereign. Exposures to Ireland, in particular through group holdings, remain small but important, as are exposures to Central and Eastern Europe (Box 1).

\section{Some banks also have significant exposures to banks abroad suggesting the risk of outward and inward spillovers (Figure 6). Network analysis, which tracks the reverberation of a} credit event or liquidity squeeze throughout the banking system via direct linkages in the interbank market, indicates that the banking system's largest direct vulnerability is to the realization of extreme credit and funding shocks to banks in France, Germany, and the Netherlands. ${ }^{9}$ Not surprisingly, given the size of the U.K. and U.S. banking sectors, shocks to banks in the United States and the United Kingdom would have an even greater, albeit second-round, impact on stability in Belgium, as shocks to these systems would trigger distress across a number of countries. In turn, an extreme credit and funding shock in Belgium would have important outward effects on the banking systems in Luxembourg, the Netherlands, and the Czech Republic (Box 2).

\footnotetext{
${ }^{9}$ The analysis is based on the Bank for International Settlements' locational statistics as of September 2012. Countries included in the analysis are the Czech Republic, France, Germany, Greece, Hungary, Ireland, Italy, Luxembourg, the Netherlands, Poland, Portugal, Russia, Slovak Republic, Spain, Turkey, U.K., and U.S. Note that global exposures of banks in the Czech Republic, France, Hungary, Russia, Poland, Slovak Republic, Turkey, and U.K .are extracted from data on liabilities of the countries' counterparties.
} 


\section{Box 1. Outward Spillovers from Belgium Financial Sector}

Belgian banks deleveraged massively since the onset of the crisis, mainly by reducing cross-border exposures. Exposures of Belgian banks to Central and Eastern Europe decreased by about 22 percent since end 2007 primarily through the disposal of foreign subsidiaries. The exposure to the Czech Republic remained high and relatively stable, with an almost equal split between loans and government securities, while banks deleveraged in the rest of the region; exposures to Turkey and Russia dropped most significantly.

\section{Continued deleveraging would have} important spillover effects in Central and Eastern Europe-the most important external market for Belgian banks. So far, however, the impact on financial intermediation has been relatively subdued. In the longer run, reduced parent funding may lead to a more sustainable business model in host countries based on an increased reliance on local savings. Host countries could also be hit by a renewed market distress should local subsidiaries come under pressure to upstream liquidity to parents, for example through disposals of local government

Belgium Banks Main Exposures on Emerging Europe (In billions of U.S. dollars)

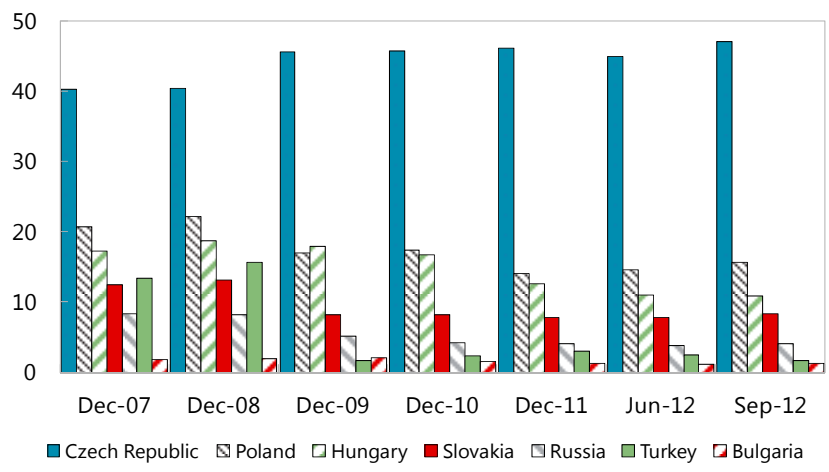

Source: BIS Consolidated Banking Statistics. Amounts outstanding based on consolidated foreign claims of reporting banks on an ultimate-risk basis. securities, or if losses were to be recorded from mark-downs of Belgian securities held by local subsidiaries.

Belgium is home to three key parts of global financial market infrastructure, the failure of which would have serious and widespread cross-border implications. Euroclear Bank operates one of the largest securities settlement systems worldwide with a daily average settlement value of around $€ 1.1$ trillion, providing settlement services for securities from 44 markets in 53 currencies. Euroclear Bank services the largest global banks with triparty repo arrangements to secure their interbank funding. Bank of New York Mellon SA/NV is the European subsidiary of the global custodial bank (designated a global systemically important institution). The institution provides clearing and collateral management, asset servicing, and treasury management to institutional clients, with the Belgian subsidiary acting as a processing center for the group's global custody activities outside the U.S. The NBB coordinates the oversight of SWIFT, which plays a vital role in the day-to-day operational conduct of financial transactions. Although SWIFT is neither a payment system nor a settlement system, a large number of systemically important firms depend on SWIFT for their daily messaging, so that SWIFT itself is of systemic importance.

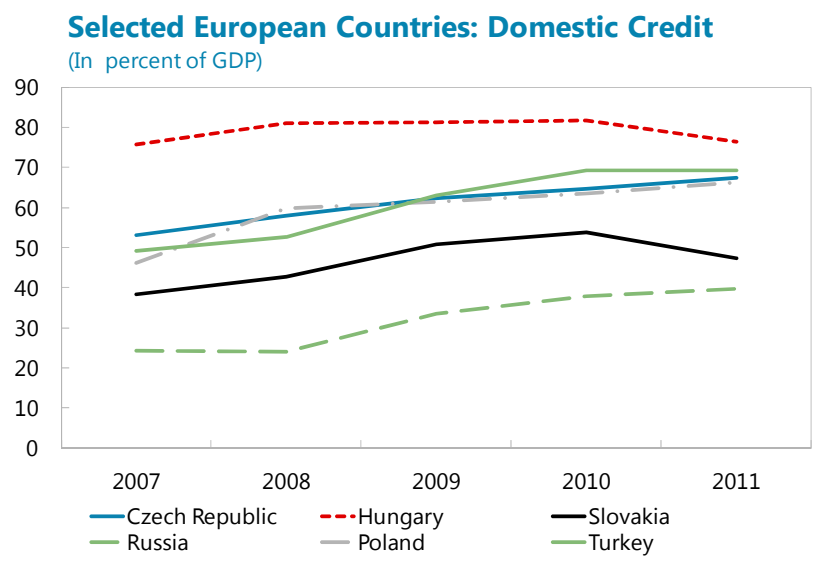

Sources: International Financial Statistics, IMF, and Economic Intellengience Unit. 


\section{Box 2. Network Analysis of Spillover Risk for the Belgian Banking System ${ }^{1}$}

Network analysis was conducted to identify financial systems of systemic importance to Belgium, as well as the main financial systems that could be affected by spillovers from Belgium. The methodology assumes the manifestation of extreme tail risks (i.e., the failure of the banking system of a country) and illustrates the relative importance of systemic linkages across countries through the global banking network. ${ }^{2}$ Spillovers are modeled by (i) estimating the "domino effects" triggered by the default of a banking system's interbank obligations (credit shock); (ii) looking at the effects of a credit-plus-funding event, where the default of a banking system also leads to a liquidity squeeze for those countries exposed to funding from the defaulting system (i.e., the credit shock is compounded by a funding shock and associated fire sale losses).

\section{The analysis is based on bilateral exposures} of banking systems across 18 countries and their capital level data at end-September 2012. A consistent definition of capital (total regulatory capital) is used for all countries. The simulation presented in the analysis refers only to interbank exposures. Key assumptions are that (i) for the credit shock, a loss given default of 100 percent is assumed on interbank exposures based on the difficulty of recovering assets at the time of bank failures, and (ii) for the funding shock, a withdrawal of 35 percent is assumed on interbank funding and a haircut of 50 percent is assumed on forced asset sales. Overall, the results are sensitive to these shock assumptions; however the relative importance of systemic countries remains the same.

The United States and the United Kingdom represent, by far, the biggest potential risk to the Belgian banking system, albeit indirectly, followed closely by France. The impact of a credit-only or credit and funding shock through the interbank markets of these three countries would be extreme, resulting in a complete or near complete depletion of regulatory capital. In addition, the Belgian banking system is also particularly vulnerable to credit and funding shocks from Germany and

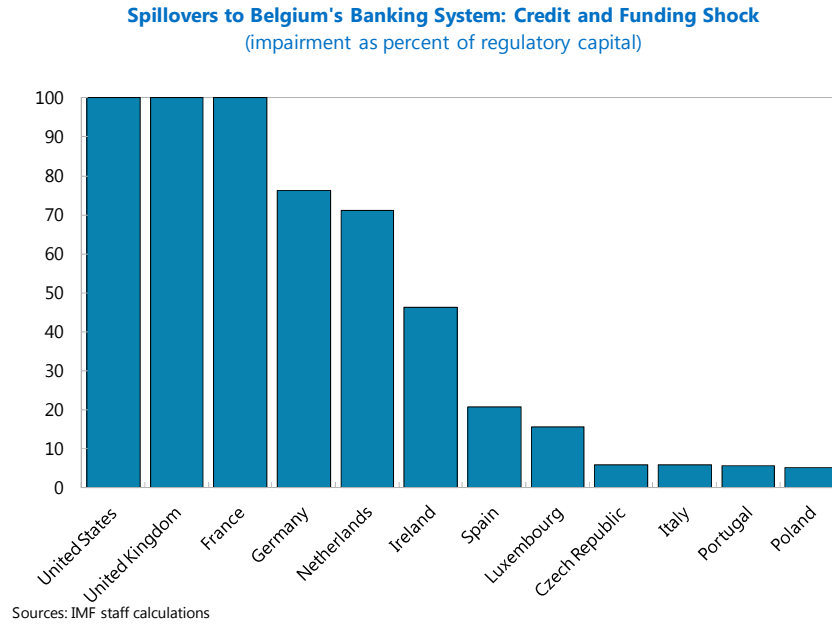

Spillovers from Belgium's Banking System: Credit and Funding Shock (impairment as percent of regulatory capital)

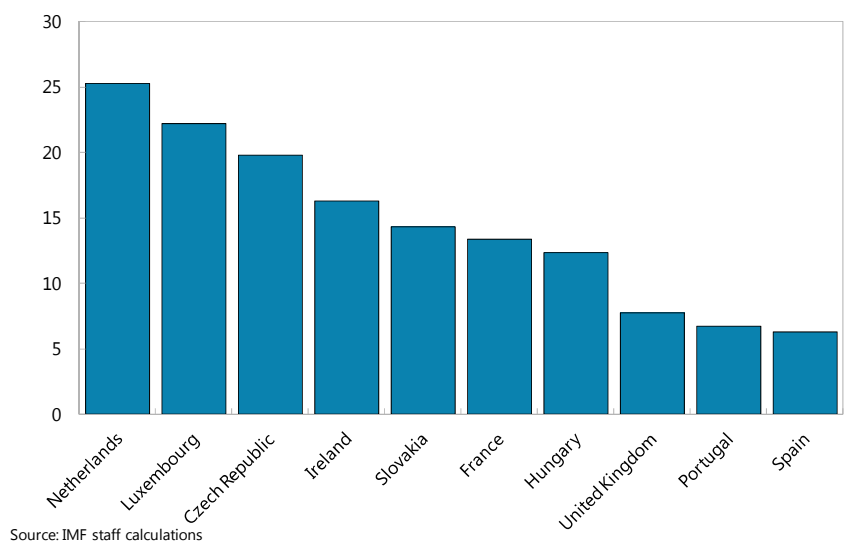
the Netherlands. The system is much less exposed to extreme tail shocks from other major economies, which would generate impairments of less than 50 percent of total capital even if those banking systems were to fail.

An extreme credit and funding shock in Belgium would affect Luxembourg, the Netherlands, and the Czech Republic most. The impact of a credit only or credit and funding shock from Belgium, propagated through the interbank markets, would be important, although confined to less than 25 percent of regulatory capital in these countries. The impact on other financial systems considered in this analysis would be relatively minor.

${ }^{1}$ Prepared by Serkan Arslanalp and Oana Nedelescu.

${ }^{2}$ Marco Espinosa-Vega and Juan Solé, 2010, "Cross-border Financial Surveillance: A Network Perspective," IMF Working Paper 10/105 (Washington: International Monetary Fund). See also Global Financial Stability Report, Chapter 2, "Assessing the Systemic Implications of Financial Linkages," April 2009 (Washington: International Monetary Fund) for an illustration of analysis and description of simulation algorithm. 
22. Several Belgian insurers have not fully recovered from the global financial crisis and continue to be challenged by economic uncertainty in Europe. Government support was extended to a few insurers to maintain the stability of the industry in 2008. The industry's solvency position has continued to weaken, however, and prospects for recovery are dampened by the legacy of high guaranteed returns. Insurers hold high levels of government bonds ( $€ 104$ billion, or 40 percent of total assets, of which $€ 60$ billion were in Belgian government bonds).

\section{The financial condition of insurance firms has generally been sound but pressure} points have emerged (Figure 7). The solvency margins computed under the current Solvency I regime tend to underestimate risks and there is a serious concern that solvency risks have built up both in Belgium and in Europe overall. A prolonged low-interest rate environment would adversely impact the earnings and claims-paying capacity of the sector over the medium term. Low interest rates heighten the re-investment risk for new funds generated from premiums, but also increase the present value of future claims, which could give rise to critical asset-liability mismatches and reserve deficiencies. Insurers have been gradually shifting towards contracts that offer lower guarantees, but the average guaranteed rate of return still stood at 3.25 percent at end-2010. ${ }^{10}$ The demand for life policies has been eroded by households' preference for liquidity and is reinforced by tax treatment favoring savings deposits in banks. Nonlife insurers have taken measures to improve their underwriting discipline, but remain susceptible to investment risks.

24. Insurers also face liquidity risks, as experienced in the crisis. A weakening of confidence can lead to surrender of policies and in the case of Belgian insurers there are few penalties for early surrender. The move to lower guaranteed rates also increases the risks of surrenders by policyholders. While intragroup transactions can assist in managing risk and liquidity to the benefit of all entities within group structures, there are risks. Liquidity management through asset swaps and transfers or through liquidity transformation transactions has boosted return for insurers but may underestimate the liquidity needs of insurers in the longer term.

\section{Bank Stress Testing}

\section{The financial sector is still susceptible to several risks (Appendix IV):}

- A new or prolonged recession in the euro area and persistently low interest rates. The growth outlook is uncertain, partly due to near-term fiscal tightening in a few advanced economies. The effect of bank deleveraging and fiscal consolidation could be larger than envisaged. Growth concerns keep interest rates low and further erode the risk bearing capacity of banks and insurers.

\footnotetext{
${ }^{10}$ According to the 2012 NBB Financial Stability Report, technical provisions associated with guaranteed rates of return for traditional individual policies totaled $€ 32$ billion (or 32 percent of the total technical provisions for this class of business) at end-2010. The NBB's prudential decision to lower the maximum interest rate from 3.75 percent to 2 percent was recently vetoed by the Ministry of Economy and Consumer Affairs on competition grounds. The NBB is empowered to intervene on a case-by-case basis if it opines an insurer offers a guarantee rate imprudently.
} 
- Renewed political uncertainty impact on market confidence. A re-intensification of market concern regarding adverse loops between banks and sovereign stress would widen sovereign and bank spreads, increase bank funding costs, and weaken external demand.

- A sharp downturn in the housing market. Model-based estimates of misalignment suggest that home prices are 5-20 percent above their equilibrium levels, leaving banks vulnerable to losses.

\section{Stress testing was used to assess banking system's resilience in the face of further} shocks. ${ }^{11}$ The stress tests considered the sector's vulnerability to a renewed economic contraction, including a substantial rise in unemployment, a further depreciation of real estate prices, and rising funding pressures. The impact of rising sovereign risk, upcoming regulatory reforms, behavioral changes of banks, and the ongoing implementation of some restructuring plans were also examined.

\section{Solvency risk}

27. Solvency stress tests were based on mid-2012 data. The two-pronged approach covered more than 90 percent of total assets of the domestic banking sector, excluding foreign branches, on a solo and consolidated basis (Table 5.1, Appendix V):

- A bottom-up balance sheet stress tests conducted by banks themselves in collaboration with the FSAP team and NBB staff based on prudential data following the guidelines provided by the FSAP team ("BU exercise"); and

- A cross-validation of results by a top-down balance sheet stress test in collaboration with NBB staff based on the FSAP team's assumptions about macrofinancial linkages ("TD exercise").

\section{Two adverse macro scenarios were used-a severe and short-term "double-dip} recession" and a protracted "slow-growth scenario" (Figure 8). The first scenario comprises a shock of two standard deviations of real GDP growth from the IMF-projected baseline over the first two years with a subsequent recovery to baseline growth path during the final three years of the five-year forecast together with a flattening of sovereign yield curve. ${ }^{12}$ In the latter scenario, a similar cumulative deviation from the baseline is distributed over the entire forecast horizon as a result of assumed continued shocks to demand, amid rising inflation expectations and a concomitant parallel shift in the sovereign yield curve. The severity of these shocks is consistent with FSAP stress testing exercises in other European countries.

\footnotetext{
${ }^{11}$ Appendix $\mathrm{V}$ describes stress testing methodology. Further details and results are provided in a Technical Note on Stress Testing.

12 The baseline projections are based on the September 2012 World Economic Outlook projection. The standard deviations for real GDP growth were calculated based on the volatility of the two-year growth rate over the last 30 years (1981-2011).
} 


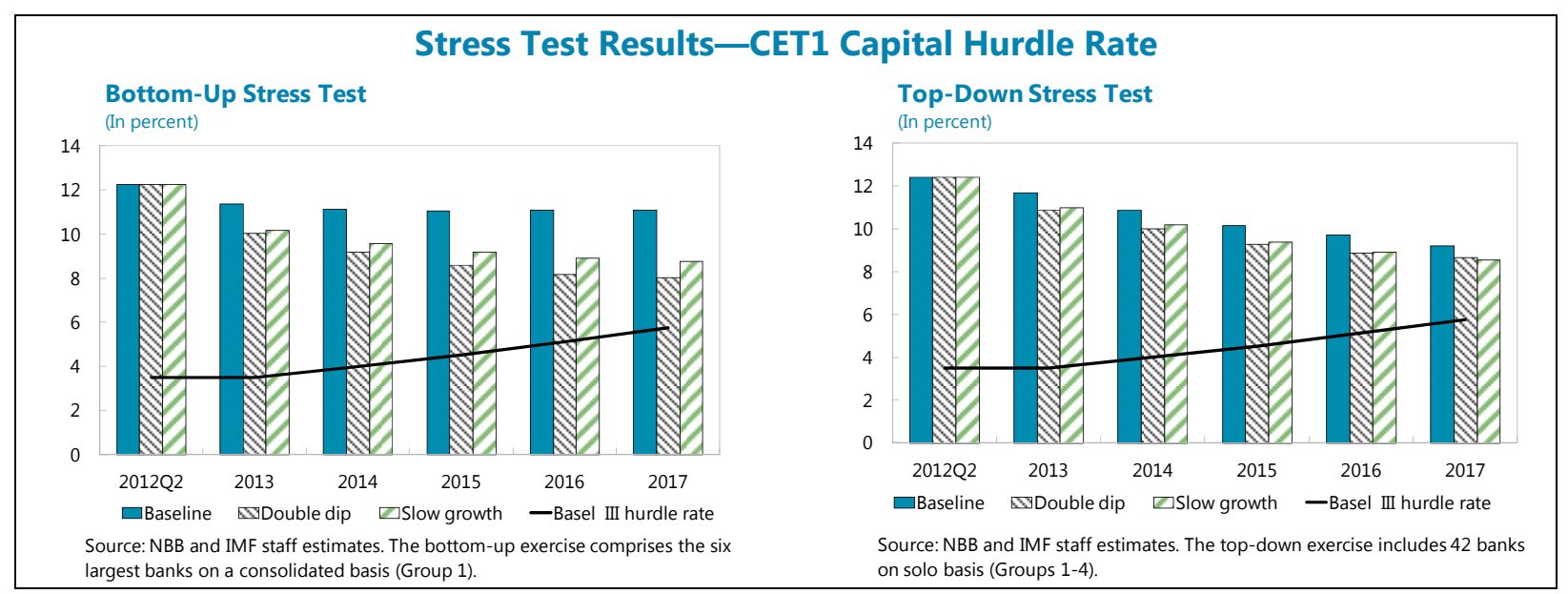

29. The stress test results suggest a significant erosion of the capital base under stress, which is concentrated in a few institutions (Figure 9). ${ }^{13}$ Under the BU approach, the Common Equity Tier 1 (CET1) capital ratio declines by 4.2 percentage points and 3.5 percentage points under the double-dip and slow-growth scenarios, respectively, while remaining on aggregate above the relevant hurdle rates throughout the forecast horizon. The findings are similar for the TD exercise. ${ }^{14}$ Given solid capital buffers, only a few institutions fall below the capital hurdle rate, by an amount that could reach up to 3.6 percent of the aggregate CET1 for the sector.

30. The results indicate a high sensitivity of banks to higher loan impairments, valuation losses from rising sovereign risk, and the impact of regulatory changes on risk-weighted assets (RWAs) and capital. The impact of these risk drivers on solvency is mitigated by historically robust credit conditions and significant balance sheet reduction allowing banks to maintain existing provisioning levels. Some larger banks in the system appear more affected even under baseline conditions. Uncertainty about the valuation of some portfolios (such as legacy assets acquired as a result of past activities abroad) could negatively affect banks' internal projections of future performance under stress. Although the macroeconomic scenarios embodied a relatively moderate shock to residential and commercial real estate prices, single factor sensitivity tests confirmed banks' vulnerability to a more severe decline. ${ }^{15}$ Some banks also maintain significant exposures to hard-tovalue credit portfolios and stress tests do not fully capture this vulnerability.

\footnotetext{
${ }^{13}$ This figure reflects the aggregate shortfall for banks that are below the CET1 hurdle rate without considering any surplus capital for banks above the hurdle rate at the time of the capital assessment.

${ }^{14}$ The TD and aggregated BU stress test results are broadly consistent with differences attributable to the model design and different scope of the two exercises. Firm-specific assumptions and use of internal models in the BU exercise (even though consistent with stress testing guidelines provided by the FSAP team) can lead to differences in the projection of profits and losses for individual firms under the various scenarios. Moreover, the BU tests were undertaken by the six largest banks at the consolidated level whereas the TD analysis was performed on a larger sample (all banks in the system excluding branches of foreign banks in Belgium) but on a solo basis.

${ }^{15}$ A single-factor sensitivity analysis was performed to gauge the impact of real estate price corrections by 15 and 25 percent.
} 
31. Sovereign risk is material and significantly affects overall results. Market-implied valuation haircuts of more than five percent on Belgium, and more than 10 percent on higher yield euro area sovereigns, were applied to all on- and off-balance sheet exposures at mid-2012 prices. This factor reduces CET1 capital in the system by more than $€ 4.6$ billion or 10.4 percent under the adverse scenarios. ${ }^{16}$

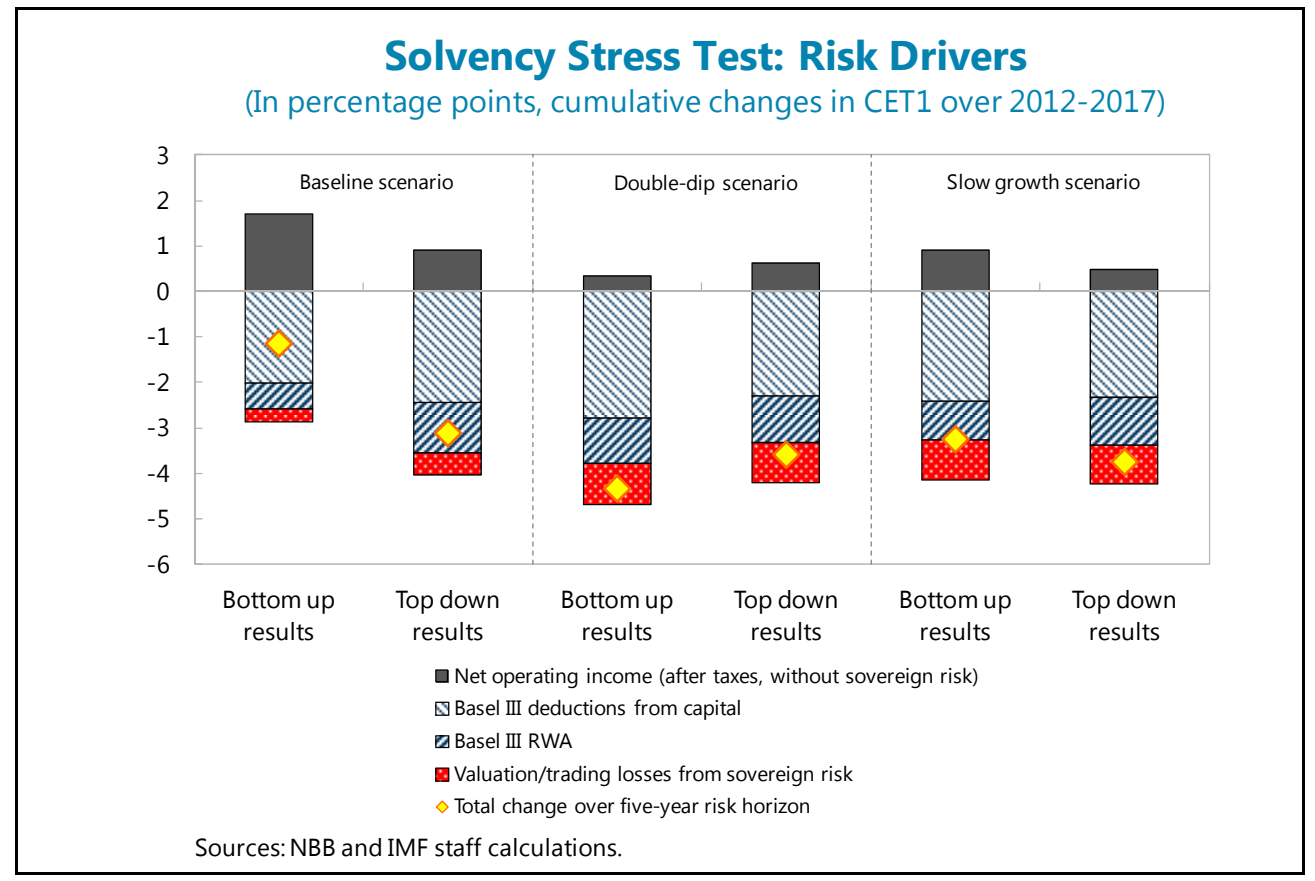

\section{Liquidity risk}

32. Most large banks have considerably improved their liquidity position over the last four years (Figure 10). Funding structures have become more favorable overall, in spite of a rising asset encumbrance relative to the amount of short-term liabilities. Banks have reduced wholesale funding, but remain dependent on market-sensitive nonbank institutional and corporate deposits totaling about one-third of the deposit base. The revised calibration of the LCR announced in January 2013 resulted in significant improvement of banks' ratios in comparison to the original calibration. ${ }^{17}$ Most banks have access to sufficient stable sources of funding due to a large deposit base, with the average Net Stable Funding Ratio (NSFR) at 112 percent. Although only four of the six largest banks

\footnotetext{
${ }^{16}$ The Technical Note on Stress Testing provides details on the sovereign risk analysis and estimation of valuation haircuts on sovereign exposures.

${ }^{17}$ Various analyses suggest that the application of the new definition of the LCR under the Basel III framework would improve the system-wide ratio from 83 percent to 103 percent, with only one institution falling below the threshold.
} 
pass the test, all exhibit NSFR ratios higher than 95 percent-just five percentage points shy of the 100 percent pass mark. ${ }^{18}$

\section{The stress test results within the national liquidity framework (NBB Liquidity Ratio)} show that most banks are able to support a shock to cash outflows (Figure 9). The regulatory liquidity stress test ratio suggests that Belgian banks have enough liquid assets to withstand a weeklong net cash outflows (on a solo and consolidated basis), with the average NBB liquidity ratio of 263 percent (against a norm of 100 percent). Extending the risk horizon to one month shows that overall liquidity shortage would remain concentrated in a very few institutions. The liquidity shortfall remains small at 0.5 percent of eligible assets. The withdrawal of contingent intragroup funding and higher liquidity risk from a moderate increase in sovereign risk do not change the results markedly. However, intragroup funding by larger institutions to their foreign parents remains significantdespite the introduction of a 100 percent of own funds limit in 2011-and places a premium on sufficient liquidity buffers at Belgian subsidiaries.

\section{Policy recommendations}

\section{The stress test results point to the need for a thematic review of identified} vulnerabilities and supervisory follow-up. The authorities should continue to carefully assess the impact of further spread compression, interest rate shocks, and the gradual deterioration of credit quality at some banks; and expedite the consolidation process to restore confidence in the domestic banking sector. Banks' capital buffers should be further strengthened with a view of forthcoming Basel III requirements. For liquidity risk, the close alignment of the Basel III LCR and the Belgian liquidity ratio suggests that the current liquidity regime should be preserved (and liquidity buffers maintained) before the LCR is fully adopted and phased in at the European level in 2018.

\section{Going forward, the authorities should enhance and embed the stress testing in the} macroprudential policy and surveillance framework. The systematic integration of both TD and BU stress testing into the supervisory framework will help inform the assessment of the financial soundness of individual firms and encourage greater involvement of supervisors in financial stability analysis. Besides the risks discussed above, other sources of vulnerability also require more granular prudential information and supervisory review, such as intragroup transactions within conglomerates under severe stress conditions or vulnerabilities from real estate overvaluation.

\section{Insurance Stress Testing}

36. The insurance stress testing assessed the capital adequacy under different shocks to single risk factors affecting both investment and underwriting performance. In the insurance sector, macro-financial linkages often vary by different business lines as well as technical factors

\footnotetext{
${ }^{18}$ Belgian banks fare well compared with European peers. The most recent EBA study, based on the old definition of LCR and end-2011 data, shows that only 37 percent of large EU banks (with capital above €3 billion) report LCR above 100 percent, with the large-bank average of 72 percent (91 percent for banks with capital below $€ 3$ billion). The average NSFR is about 93 percent, with only 40 percent of the sample having enough stable funding.
} 
influencing the pricing and reserving of insurance products. Thus, the stress test comprised single factor shocks to a selected set of risk drivers that were directly inferred-or reasonably sensitive-to the general economic scenarios examined in the banking sector stress test. The impact of general conditions affecting risk factors, such as rising sovereign risk and upcoming regulatory reforms, was also examined to reflect future transition from the current Solvency I to Solvency II standard.

\section{Solvency risk}

\section{Stress testing of insurer solvency was undertaken as a bottom-up exercise using a} combination of single factor shocks affecting each capital component. The stress test covered the six largest insurers (Ageas, AXA Belgium, Belfius Insurance, Ethias, KBC, P\&V - Vivium Group), comprising more than 70 percent of the insurance sector, and was conducted by insurers themselves in collaboration with the FSAP team and NBB staff. The NBB defined market developments under two adverse scenarios (mild and severe) together with a mass lapse event in the life business and the realization of the largest probable maximum losses ( $P M L)$ on a single (man-made or natural) catastrophic tail event. Firms calculated the overall capital impact by aggregating the individual impact of these shocks, using a correlation approach. The own funds available after the scenarios occurring are then compared with the Solvency Capital Requirement (SCR) and the Minimum Capital Requirement (MCR), subject to eligibility conditions. ${ }^{19}$

\section{The impact of individual stress scenarios was calculated for Solvency I, solvency standard in the latest EU quantitative impact study (QIS 5), and a full "market-consistent} valuation" (MCV) method. Even though the current regulatory regime is based on Solvency I, the absence of risk-based elements makes it unsuitable for the quantification of the capital impact of economic shocks. Equally, elements (i.e., the illiquidity premium) of QIS 5 dampen by construction the economic impacts of spread and interest rate movements. The MCV overcomes these valuation concerns and allows for a more realistic capital assessment.

\section{Insurers' capital levels are sufficient under the current regulatory regime but} vulnerabilities are apparent when a more risk-based solvency framework is applied. With the exception of one firm, all insurers exceeded the Solvency I hurdle under both the mild and severe adverse scenarios. The results suggest that hidden reserves (i.e., net unrealized capital gains or losses in excess of unrealized capital gains included in the statutory solvency margin), were sufficient to buffer the impact of shocks to market risks as well as an escalation of underwriting risks. While a few insurers exhibit sufficient capital buffers when measured using the more risk-sensitive valuation methods, most firms are likely to experience a significant decline in solvency ratios in response to rising asset-liability mismatches, higher credit spreads, and a general increase of sovereign risk. Assuming full market consistent valuation, the sector was severely undercapitalized under both stress scenarios, calling into question some business models if the low interest rate environment persists over the medium term. It is important to note that the stress test was much stricter than the

\footnotetext{
${ }^{19}$ This is an acceptable simplification, even though the SCR and the MCR after an event occurs will be different than when calculated pre-scenario, as the main effect of the scenario is on own funds, rather than on SCR.
} 
valuation being discussed currently for future Solvency II regime in the EU since it did not include any mitigating factors (i.e., illiquidity premiums, swap rates or matching adjustments) and was based on a pure risk-free discount rate.

\section{Insurance Stress Test Results}
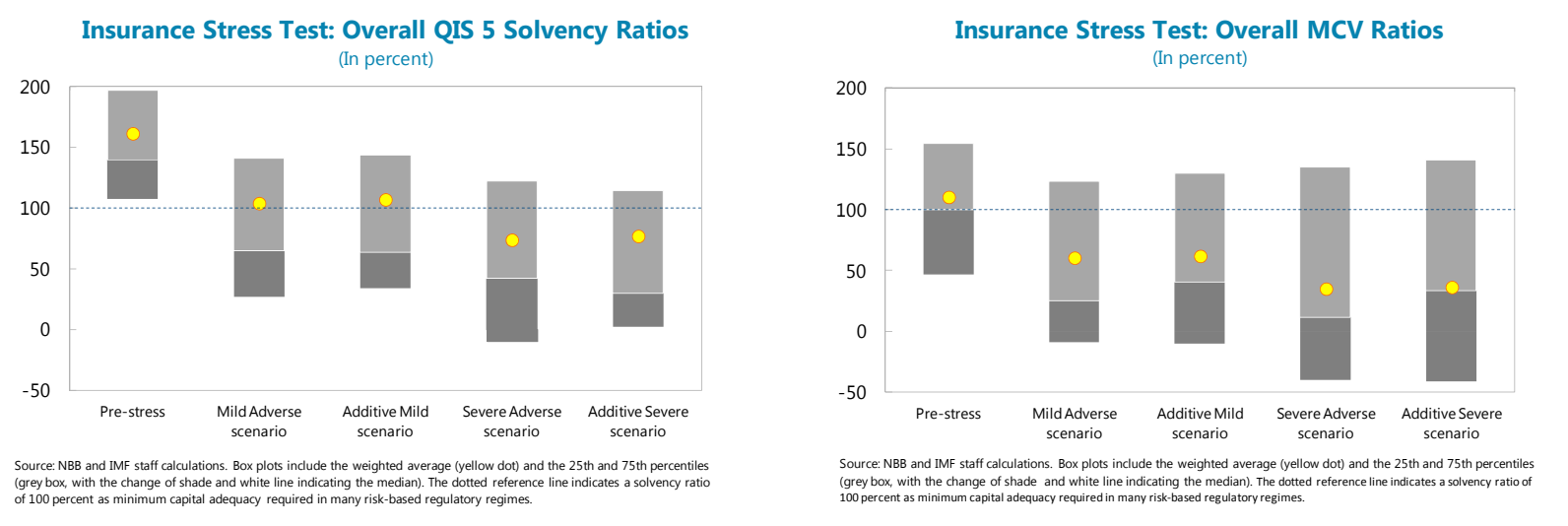

40. The solvency position of insurers is significantly impacted by sovereign risk. The market-implied valuation haircuts used for the banking sector stress test have also been applied to all direct and indirect exposures of insurers at mid-2012 prices. These decrease the QIS-5 solvency ratio with weighted solvency components (SCRs) by 45 and 54 percentage points under the mild and severe adverse scenarios, respectively (and between 30 and 46 percentage points without using a correlation approach for aggregating risk factors).

\section{Liquidity risk}

41. Liquidity risk could further amplify solvency pressures on insurers within conglomerate structures under a more risk-sensitive valuation standard. A rise in credit spreads in tandem with greater market uncertainty will put a premium on the asset liquidity of insurers' investment portfolio. In particular, insurers that are part of a conglomerate might find it expedient to transfer their liquid assets in exchange for illiquid ones from the banking operations potentially increasing the expected yield of their assets. However, the stress test shows limited tolerance for liquidity risk in particular for those insurers that experience a significant capital shortfall in the baseline and adverse scenarios.

\section{Policy recommendations}

42. Authorities are encouraged to apply an economic balance sheet approach in assessing the solvency position of insurers under stress on a regular basis. The stress tests can inform a thematic review of key individual and system-wide vulnerabilities of insurers to specific events and risk factors and help integrate stress testing with the prudential supervision of insurers. Such an 
analysis, if based on a MCV standard, would allow the NBB to determine the extent to which dampeners used in Solvency II could distort the picture of the actual solvency position of insurers. ${ }^{20}$

\section{Developing a medium-term strategy for consolidation in the insurance sector is} warranted. For insurers that are overly exposed to adverse but plausible shocks, contingency plans should be prepared by both insurance companies and the authorities. For groups and conglomerates, increasing focus should be placed on potential secondary effects in situations where scenarios cause financial strain, i.e. the impact of rating downgrades and spillover and contagion effects between different legal entities within groups and conglomerates via intragroup transactions.

\section{FINANCIAL STABILITY FRAMEWORK}

\section{In the aftermath of the crisis, the regulatory and supervisory structure has been re-} organized and the authorities took a number of steps to strengthen the oversight framework. The new architecture, effective since April 2011, replaced the integrated regulator (the Commission Bancaire, Financière et des Assurances, CBFA) and allocated the prudential supervision of financial institutions to the NBB and the responsibility for ensuring market conduct and consumer protection to the FSMA. ${ }^{21}$ All bank and prudential insurance supervision staff moved to the NBB. The primary driver of the new structure was to leverage the synergies between the NBB's responsibility to safeguard financial stability and prudential supervision, allowing the new FSMA to focus on market regulation and consumer protection.

45. The new institutional architecture remains a work in progress. Formalization of the arrangements for cooperation and coordination between the NBB and the FSMA is ongoing. Reliance on a highly detailed set of provisions in a Royal Decree is no substitute for guidance governing cooperation and coordination at all levels, including assigning responsibilities for communication and coordination within the institutions, defining objectives and areas of mutual concern, and developing a set of objectives and tracking mechanisms for technical staff on information sharing and joint engagements. To this end, a broad MOU on cooperation between NBB and FSMA came into effect in March 2013, supplementing already existing MOU in relation to Financial Markets Infrastructure. ${ }^{22}$ Implementation of this MOU will over time improve the effectiveness of the new regulatory architecture.

\footnotetext{
${ }^{20}$ The MCV used in the stress test is based on replicating insurance liability cash flows with sovereign bonds only. These have reliable market prices and do not introduce additional credit or liquidity risks into the valuation. In this sense, this economic valuation results in a maximally reliable and objective view of the economic costs of the insurance liabilities. In contrast, valuation standards that use illiquidity premiums or matching adjustments—such as currently discussed for Solvency II-introduce additional valuation uncertainty (e.g., via the replication with illiquid financial instruments or with the assets being held by the insurer).

${ }^{21}$ The "Twin Peaks Law" (Royal Decree of 3 March 2011) came into force April 2011.

${ }^{22}$ Following the FSAP mission, a general MOU on collaboration between the NBB and the FSMA to ensure coordination of the supervision of institutions under the respective supervision of the two agencies was concluded on March 14, 2013. See http://www.fsma.be/en/About\%20FSMA/mou/samenwerkingsaccord.aspx.
} 
46. Financial stability risks underscore the need for more intensive and intrusive supervision. Promoting a supervisory culture in which the "will to act" is both expected and rewarded will be key to managing the challenges still present in the rapidly transforming system.

\section{Belgium is in the process of designing a comprehensive macroprudential policy}

framework. A comprehensive methodology was formulated in 2011 to identify domestic systemically important financial institutions (banks, insurance companies, and holding companies). The NBB can impose supplementary reporting and prudential requirements, the operational aspects of which are yet to be clarified together with a broader application of RRPs. The NBB and FSMA have broad instruments to monitor and address the cyclical part of the systemic risk.

48. The NBB is best placed to become the designated macroprudential authority. The authorities are still debating the optimal structure and governance for macroprudential oversight. While there is no "one size fits all" model for the macroprudential construct, there is growing recognition that the macroprudential authority should have willingness to act in a timely manner while having sufficient powers to identify, assess, and mitigate systemic risks. ${ }^{23}$ Given its broad supervisory mandate, its statutory financial stability objective, and extensive regulatory powers, the NBB is best placed to become the designated macroprudential authority. ${ }^{24}$ Ongoing EU-wide policy discussions and the launch of the SSM will have an impact on the toolkit ultimately available to national authorities, which should ideally be able to effectively tackle domestic systemic risks. Adequate accountability mechanism would need to be designed while periodic consultations should take place with other relevant authorities, such as the FSMA and the MOF, to ensure a holistic view and effective coordination across policies to address systemic risks.

\section{A. Banking Supervision}

\section{Belgium has a high level of compliance with the Basel Core Principles for Effective} Banking Supervision (BCPs). This level of compliance, achieved in a challenging environment, was facilitated by structural changes and regulatory reforms, made in response to the financial crisis, which introduced new supervisory powers and re-oriented supervisory practices.

\section{The NBB deploys high quality risk-based supervisory practices-which it is building} upon through well conceived initiatives and reforms-but baseline supervisory intensity and allocation of resources warrant improvement. Some enhancements to risk oversight, such as an annual risk review, are already in place and are being underpinned by a focused action plan that will improve analytical processes and substance. The NBB should use its new tools to identify the minimum adequate level of supervisory attention for each institution according to that institution's risk profile. Further, the NBB should proceed with planned enhancements to peer group cluster

\footnotetext{
${ }^{23}$ See International Monetary Fund (2011), "Institutional Models for Macroprudential Policy," Staff Discussion Note 11/18, November 2011.

${ }^{24}$ Art. 12 of the Statute of the NBB formulates NBB's financial stability objective.
} 
analysis, which will help develop a baseline program to establish minimum supervisory interaction with a firm while improving risk-focused allocation of resources.

51. The large exposure regime should be strengthened. At present national regulation permits smaller banks to extend exposures up to a limit of 100 percent of own funds, if the exposure itself is $€ 150$ million or less. As a result, smaller banks may become vulnerable to concentration risk. There is also no requirement for the banks' senior management or board to take the credit decision when an exposure exceeds a certain limit. This deficiency should be remedied as oversight or direct approval by the Board promotes a group-wide view of risk important in view of prevailing conglomerate structures. The NBB should execute plans to enhance governance requirements for groups, by stating more explicitly what is expected of the parent company in respect of coordinating and controlling the group in a holistic way.

52. The NBB is actively engaged with counterparts and participates in supervisory colleges for its systemically important financial institutions. The supervisor has undertaken joint projects, joint risk assessments, and joint decision making with key foreign counterparts and is using the supervisory college environment to focus on risk management and adequate distribution of capital within groups.

53. Direct engagement by supervisors with the bank boards should be enhanced. The regulations require boards to approve risk management strategies and the ICAAP on at least an annual basis. While the NBB assesses the board, it should engage more directly with the full board to challenge board members' appreciation of the risks, the implementation of risk management, and adequacy of capital, and to ensure the board is discharging its role effectively. This type of frequent and close engagement will enhance the NBB's oversight of risk management, especially in areas that are often less transparent in a large group. Examples include intragroup exposures and related party transactions, which are more complex in a large group and where conflicts of interest need to be closely managed by the board.

\section{The authorities are reviewing the desirability and feasibility of introducing structural} measures to limit bank activities. ${ }^{25}$ In response to a request from the MOF, the NBB has presented its provisional views on potential measures that seek to improve the stability of the Belgian financial system and improve bank resolvability The NBB is tasked with finalizing its proposals before the 2013 summer break. The NBB has also been invited to formulate for the beginning of May 2013 proposals for interim measures in order to limit the exposure of depositors to the risks resulting from trading activities performed by financial institutions for their own account. ${ }^{26}$ In parallel, the authorities should continue the comprehensive evaluation of the business models of important banks and expand the RRP pilot project conducted in 2012, which would usefully inform any further decisions to improve the sustainability and resolvability of financial institutions.

\footnotetext{
${ }^{25}$ Structural measures would seek to limit, separate or prohibit particular activities or legal structures within banks or financial groups.

${ }^{26}$ See http://ec.europa.eu/internal market/bank/docs/high-level expert group/report en.pdf.
} 
55. Maintaining and improving national capacity to monitor and safeguard financial stability will remain important even after the launch of the single supervisory mechanism (SSM) in the euro area (Box 3). The NBB will continue to be responsible for supervision in a transition phase. While the activation of the SSM and other banking union building blocks should result in a significant transfer of authority and responsibility to the European Central Bank (ECB), operational supervisory responsibilities at a national level could remain significant for the time being. Supervisory functions that will remain at the NBB will need adequate support, and so will the decision making on banking matters for institutions supervised by the ECB. The importance of the conglomerate model in Belgium will necessitate very close contact between the ECB and NBB in operational matters and in decision making as insurance and market conduct supervision will remain at the national level. It thus remains important to press ahead with further improvements to the supervisory practices and framework in Belgium. 


\section{Box 3. The Impact of the Banking Union on Belgium}

A draft agreement announced by the EU Council on December 14, 2012 on the adoption of the SSM represents a major step toward a banking union in the euro area and will have a significant impact on the supervisory landscape in Belgium. As currently foreseen, the SSM will come into effect March 2014 (or one year after the legislation enters into force, whichever is later). The ECB would have authority to supervise all banks in participating countries, but for the moment plans to exercise direct supervision only over "significant" institutions for the EU, a member state, or in terms of cross-border activities, or to those institutions requiring ESM financial assistance. ${ }^{1}$ Preliminary estimates by the authorities indicate that 90 of the 106 Belgian credit institutions, representing over 95 percent of the banking system's assets, will be supervised by the $E C B$, with operational details for national supervisors yet to be determined. Both the ECB and national authorities will be able to make use of macro-prudential instruments.

Belgian authorities and market participants see important benefits stemming from the SSM. The SSM could facilitate a more integrated supervisory oversight of banks operating in several countries, provide a level field for participating institutions, and reduce home biases and excessive ring fencing by national regulators. Together with other building blocks of the banking union, notably a common resolution framework, it could eventually address the negative feedback loop between sovereign and bank risks.

Important tasks lie ahead in the implementation of the SSM:

- Much remains to be done for the SSM to become effective. The draft legislation is yet to be finalized; there is a need for further clarification of the respective roles for the ECB and national authorities, both in the transition period and in the future steady state; while the supervisory capacity at the ECB is yet to be created.

- $\quad$ Given the importance of conglomerates and the bancassurance model in Belgium, the current synergies in the supervision of the banks, insurance, and other nonbank financial activities could be diluted. In the new setup, it will be important to ensure close coordination and linkages between the supervisory functions that will remain at the NBB (insurance and non-SSM banks) and the ECB bank supervision.

- Home-host relations will be affected, in the Belgian context, raising challenges for organizing a dialogue with non-EU countries and non-euro area countries that opt to remain outside the SSM. Ensuring effective coordination with hosts outside the SSM and their meaningful participation in the decision-making processes will be important.

- The degree of success in creating a common deposit insurance system and adopting a single resolution mechanism, with appropriate backstops, is likely to determine the extent to which key objectives of the banking union are achieved and the bank-sovereign feedback loop is weakened.

${ }^{1}$ Banks are considered significant if (i) their assets exceed $€ 30$ billion, (ii) the ratio of total assets to GDP of the home member state exceeds 20 percent, or (iii) national competent authorities consider it significant. 


\section{B. Insurance Supervision}

56. The authorities have made significant progress since the last FSAP, but scope remains for further strengthening the regulation and supervision of the insurance sector. The authorities have implemented strengthened solvency requirements for life insurers with exposures to legacy portfolios and enhanced the risk management requirements for insurers. The NBB has improved its supervisory framework, integrating vertical analyses of individual insurers with horizontal reviews of the insurance sector, leveraging its macroeconomic competencies. Going forward, a regular review of the practical implementation of the new institutional structure is needed to ensure that the overall supervisory objectives for the insurance sector are effectively achieved. A more principles-based approach in delegating legal authority to the NBB to issue enforceable rules would facilitate supervisory discretion within the parameters set by the law. The NBB should be empowered to take immediate recovery measures notwithstanding an appeal by an insurer. Further, the NBB should articulate clear policies to deal with potential conflicts in supervisory objectives, e.g., between financial stability and prudential safeguards for policyholders.

\section{The updated regulatory framework has a relatively high level of observance with the} Insurance Core Principles (ICPs), although there are gaps. The NBB's decision to enhance the current solvency regime ahead of the implementation of Solvency II in the EU is welcome and should contribute to a more robust evaluation of insurers' risks. Further improvements in the NBB's riskbased supervision could be achieved through the formulation of an appropriate baseline supervisory program; internal policies for inspecting functions outsourced by insurers; and review of the effectiveness of contributions of external auditors and the role of actuaries. It is critical that the NBB is adequately resourced to achieve the appropriate supervisory intensity and effectiveness.

\section{The authorities are advised to review current conduct-of-business regulation and} supervision. There is scope to raise the level of professionalism of intermediaries to deter unhealthy competition arising from more than 17,000 of them. The FSMA proposal to adapt the EU Markets in Financial Instruments Directive 2 to insurers and insurance intermediaries, is welcome. The FSMA should be empowered to establish enforceable rules on handling of claims and proper policy servicing by insurers; group market conduct requirements; and combating and reporting insurance fraud by intermediaries. The FSMA needs to strategize a risk-based approach to deal with the large population of regulated entities and ensure adequate resources for its supervisory strategy.

\section{Conglomerates Supervision ${ }^{27}$}

59. The Belgian authorities have been prudent in their supervisory approach for financial conglomerates (FCs), within the constraints of the EU-wide framework. To the extent possible, the NBB and its supervisory predecessor chose to apply the stricter regulatory regimes allowed under the EU legislation (i.e., consolidated banking supervision) in order to preserve stronger

\footnotetext{
${ }^{27}$ Technical Note on Financial Conglomerates Supervision provides additional detail.
} 
supervisory powers and tools over FCs. However, the Belgian framework also incorporates the shortcomings of the EU framework, including limited supervisory powers and tools applicable to FCs headed by mixed financial holding companies (MFHCs), as well as weaknesses in the conglomeratewide capital and liquidity measurement and requirements. A planned revision of the relevant EU directives would address some of the existing gaps in supervisory powers and tools at the level of MFHCs, while other changes will depend on further EU-wide changes.

\section{The NBB should put in place a more comprehensive approach to conglomerate}

supervision. Individualized sectoral strategies and programs currently in place may hide conglomerate-wide specific risks such as contagion and conflict of interest, and could misguide the overall aggregation and evaluation of risks. A more comprehensive and consistent approach is needed to detect multiple leveraging of capital, monitor intragroup transactions and exposures, and group-wide concentrations. The development of a uniform set of expectations regarding all FCs, elaborated internally within the NBB as a baseline for supervision of this type of group, is recommended, together with an improvement in the risk scorecards for the insurance and the securities sectors will enhance the assessment of cross-sectoral risks.

\section{More active supervisory involvement is necessary to complement self-reporting and} auditors' checks. While the governance guidelines applicable to FCs are relatively comprehensive, the NBB should ensure that they are consistently applied to address conflicts of interests within the group and should conduct more validation and back testing to strengthen integrity within the self-reporting and audit check mechanisms. The overall assessment of the internal control and risk management would be also enhanced though a better articulation of the supervisory processes, such as the internal capital adequacy assessment reporting by the group, more frequent on-site reviews, and discussions with the board and management, as well as with internal and external auditors. This would promote greater use of available supervisory data for ongoing supervision, benchmarking across conglomerates, and forward-looking cross sectoral risk assessments, including identification of build-up of risks at an early stage. Formalizing cooperation between the NBB and FSMA will enhance effectiveness of conglomerate supervision.

\section{Securities Markets and Regulation ${ }^{28}$}

\section{A full International Organization of Securities Commission (IOSCO) Principles} assessment was not undertaken. The mission focused instead on an evaluation of product regulation, the adequacy of the new regulatory structure and compliance with the new IOSCO principles, including systemic risk monitoring. The FSMA's future work should build on its existing work in relation to investor education and protection initiatives. It should give priority to resourcing the execution of its newly designed programs.

63. Formal structures are needed to embed important processes relating to identifying and managing emerging and systemic risks. The FSMA is building its skills and competency in

\footnotetext{
${ }^{28}$ Technical Note on Securities Regulation provides additional detail.
} 
monitoring and analyzing market developments in Belgium and developments regionally and globally which affect Belgium. It should ensure it builds on these competencies to drive timely responses to emerging and systemic risks. The FSMA will benefit from developing formal structures around risk identification and collaboration with the NBB. An Emerging Risk Committee should be established with formal collaboration protocols with the NBB.

\section{E. Soundness and Oversight of Market Infrastructures ${ }^{29}$}

\section{Euroclear Bank was the subject of a full Committee on Payment and Settlement} Systems (CPSS)/IOSCO Principles for Financial Market Infrastructures assessment in the context of the EU FSAP. ${ }^{30}$ The EU FSAP assessment revealed that important risk measures have been taken to reduce systemic risk, but some of them need further improvement to fully observe these recently adopted international standards. Euroclear Bank has recently substantially improved the quality of its collateral and liquidity management frameworks. In anticipation of the emerging international regulatory standards and frameworks on recovery and resolution of FMIs, Euroclear Bank has developed recovery plans and plans for the orderly winding down of its operations. It should take measures to be operationally ready for their implementation. Operational risk is wellcontrolled. Contingency plans and back-up facilities are in place to allow for timely recovery of operations and completion of the settlement process. Going forward, it should upgrade risk management policies and practices to reduce any potential unsecured credit exposures to participants and other linked securities settlement systems.

\section{Euroclear Bank is subject to regulation, supervision, and oversight of the NBB and} FSMA, but cooperation with the Luxembourg authorities should be improved. The legal framework provides the Belgian authorities with sufficient powers to obtain timely information and induce change. However, as Euroclear Bank offers similar settlement and banking services to the Luxembourg based Clearstream Bank Luxembourg, closer cooperation with the Luxembourg authorities is needed to ensure a level playing field in the implementation of risk management measures in line with the CPSS/IOSCO principles. Such cooperation already exists in relation to the interoperability link (the "bridge"). Given the importance of these FMIs to global financial stability, reinforcing and broadening of the scope of this cooperation, with the involvement of the ECB, would allow the Belgian and Luxembourg authorities to coordinate their recommendations and to seek their parallel implementation in both entities. Upon the implementation of the SSM, both Clearstream Bank and Euroclear Bank will come under the ECB umbrella, potentially leveling the playing field.

66. The Belgian, French, and Dutch authorities cooperate effectively on national securities depositories. Their national securities depositories share a common settlement platform provided by the Euroclear Group, and are subject to regulation, supervision and oversight by their respective

\footnotetext{
${ }^{29}$ This section draws on the assessments conducted during the EU FSAP in November and December 2012.

${ }^{30}$ CPSS/IOSCO Principles for Financial Market Infrastructures.
} 
national authorities. Crisis management frameworks are in place and are regularly tested and updated.

\section{F. Crisis Management and Safety Nets $^{31}$}

67. The Belgian institutional setup for crisis management is largely appropriate, but adoption of explicit coordination arrangements would be beneficial. The authorities are encouraged to strengthen the mandate of the NBB as the resolution authority, building on the Financial Stability Board's Key Attributes of Effective Resolution Regimes for Financial Institutions. ${ }^{32}$ While the new supervisory architecture was designed to avoid regulatory arbitrage and a duplication of tasks between authorities, consideration should be given to reviving the crisis preparation and management MOUs in place before the institutional changes were introduced. The establishment of a cross-institutional Coordination Group would offer a suitable platform for joint risk assessments and scenario analyses, coordination of crisis management simulations related to operational process and enhanced policy coordination needed in case of financial distress. The latter is particularly important in situations where the need for public support cannot be a priori excluded.

68. Progress has been made in the area of recovery planning. Authorities are requesting recovery plans from the domestic systemically important banks and systemically relevant financial market infrastructures. Going forward, the development of resolution plans should ensue, where relevant in cooperation with international peers, while a legal requirement needs to be created for the formulation of RRPs for all firms that are of systemic importance, including for insurers.

69. The framework for orderly resolution has been enhanced, but weaknesses remain. The NBB can utilize a range of measures to intervene proportionally should a bank breach the law or prudential regulations. The emergency liquidity assistance framework functioned adequately, while the government was able to support banking system via guarantees and public recapitalization. While appropriate at the height of the crisis, the introduction of better options for loss allocation could be now considered, such as 'bail-in' tools foreseen by the draft EU Bank Recovery and Resolution Directive. A procedure to transfer assets and liabilities of, or shares in, systemically important firms (introduced in 2010) should be revised to reduce the uncertainty and mitigate potential stability risks entailed in the ex ante judicial review. In addition, it would be desirable to broaden the scope of such powers to holding companies and nonsystemic situations, with the latter allowing for more cost effective resolution strategies. Finally, powers of special inspectors should be strengthened, with the aim to either restore the institution or prepare it for orderly liquidation.

\section{The liquidation framework should allow for rapid transfer of critical operations.}

Bankruptcy proceedings are based on corporate bankruptcy procedures and appear ill suited to address the specific features of credit institutions. The liquidation processes should be enhanced to

\footnotetext{
${ }^{31}$ Additional details are provided in the Technical Note on Crisis Management and Bank Resolution Framework.

32 See http://www.financialstabilityboard.org/publications/r 111104cc.pdf.
} 
provide for the rapid transfer of critical operations (e.g. payments, custody, clearing and settlement systems) to a third party, under the oversight of the resolution authority, while the remainder of the estate is dealt with in accordance with the general regime.

71. The deposit guarantee scheme needs to be revamped. Protection is provided by a twotier system comprised of the Protection Fund for Deposits and Financial Instruments (established as an autonomous public institution with legal personality) and the Special Protection Fund for Deposits and Life Insurance (operating under the Belgian Treasury). The creation of a segregated fund, financed via ex ante industry contributions and with robust arrangements for back-up funding, would increase transparency and allow for prompt and cost-effective payouts. The current resources of both existing funds should be folded into the new scheme. A sufficiently ambitious minimum target fund size should be set, eventually allowing the fund to absorb a simultaneous default of multiple midsized institutions. Going forward, authorities are encouraged to exclude shares issued by cooperative corporations from future coverage under the deposit guarantee scheme and to consider the introduction of depositor preference. The recalibrated deposit insurance scheme should be allowed to contribute funding to resolution actions, up to the amount of its distributions in case of a deposit payout.

\section{G. Anti-Money Laundering and Combating the Financing of Terrorism (AML/CFT)}

\section{In line with the relevant IMF Board decisions, a full reassessment of Belgium's}

AML/CFT framework is required. Belgium was last assessed in 2005 by the Financial Action Task Force (FATF), a new assessment by the FATF is tentatively scheduled in September 2014. Although outside the 18-month timeframe, under the circumstances the planned FATF assessment is acceptable for the purposes of the current FSAP. ${ }^{33}$ The 2005 assessment found that, overall, Belgium's AML/CFT framework largely complied with the standard. This was, in particular, the case with respect to the criminalization of money-laundering and terrorist financing. Shortcomings were nevertheless identified, notably with respect to the supervision of nonbank financial institutions, transparency of beneficial ownership and control of legal entities, regulation of designated nonfinancial businesses and professions, and to the freezing of terrorist assets. Since 2005, it appears that the authorities took steps to address the shortcomings identified in the assessment report. As reported by Belgium to the FATF, these steps include measures to reinforce the framework for the freezing of terrorist assets (2006), and the adoption of a new AML/CFT law (2010).

\section{The NBB's current practice in integrating AML/CFT processes into overall supervisory} process was examined in the course of the BCP assessment. The mission was unable to conclude that AML/CFT compliance is sufficiently embedded in the supervisory framework. Specifically, it is unclear how monitoring of compliance is undertaken for those smaller banks that are subject to onsite inspections only infrequently.

\footnotetext{
${ }^{33}$ The FATF does not have sufficient capacity to advance the assessment given that there are other countries that face the same issue as Belgium.
} 
Figure 1. Belgium: Structural Features of the Financial Sector
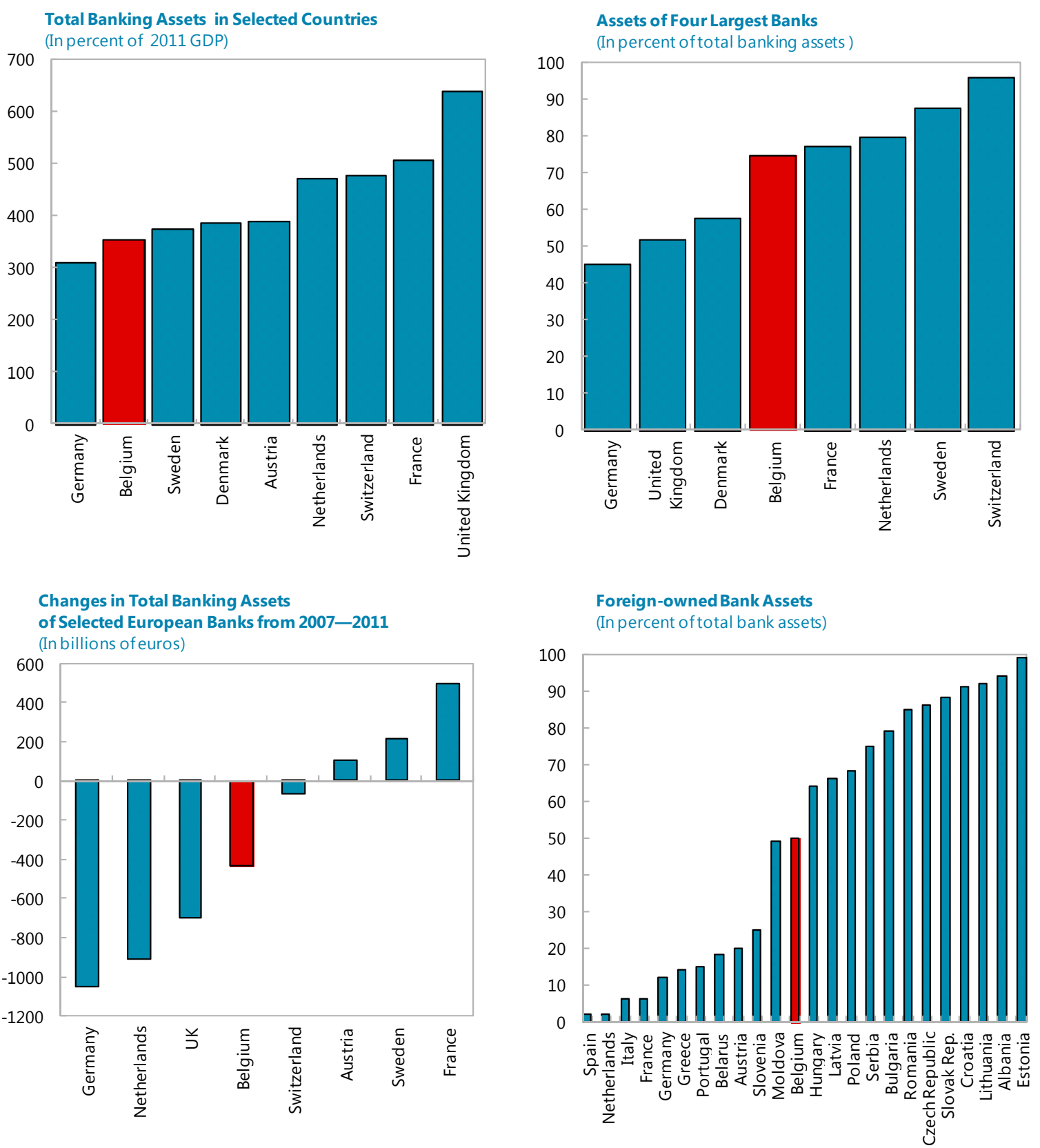

Source: NBB, SNL database, IMF Working Paper No. 12/10, and IMF staff calculations. In Belgium the four large banks are BNP Fortis, KBC Bank, Belfius Bank, and ING Belgium. 
Figure 2. Belgium: Economic Developments
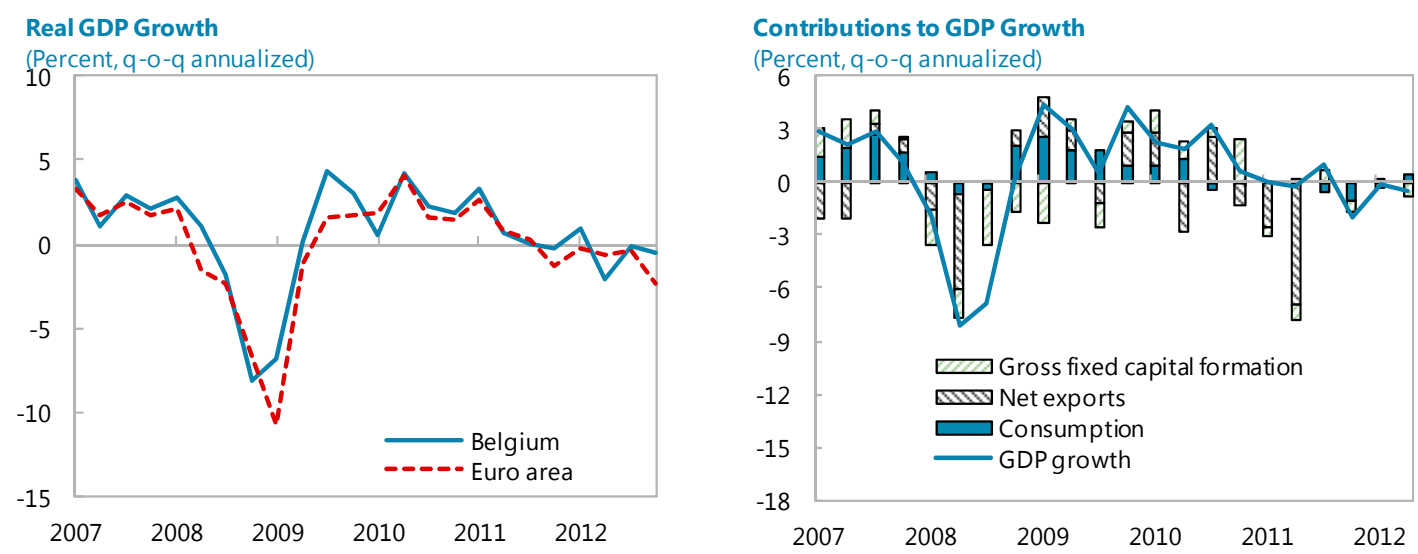

Consumption Growth

(Year-on-year percent change)

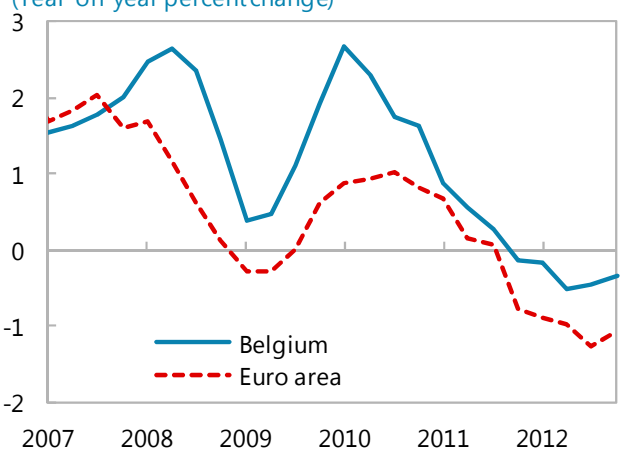

Exports Growth

(Year-on-year percent change)

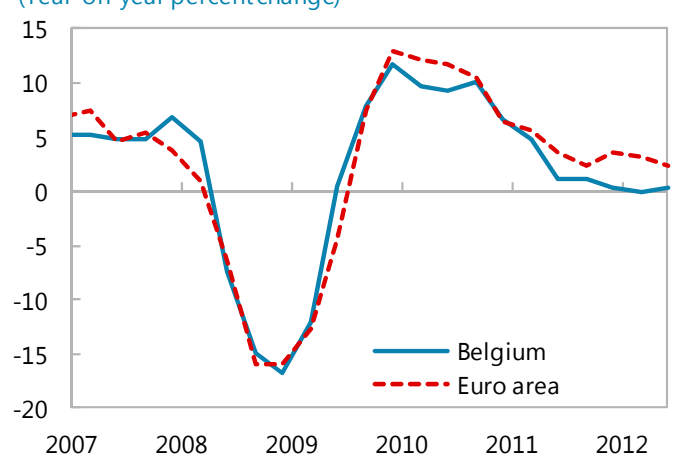

Investment Growth

(Year-on-year percent change)

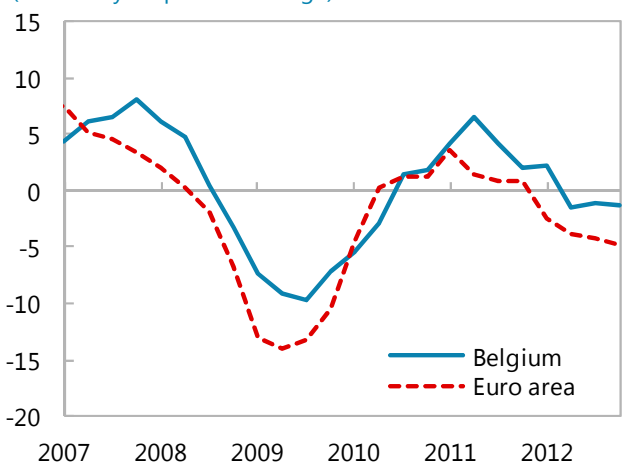

Consumer Confidence Survey

(Balance, seasonally-adjusted)

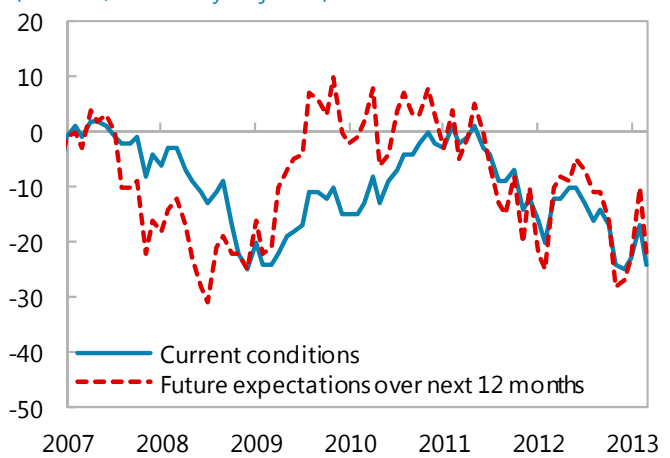

Source: Haver Analytics and IMF staff calculations. 
Figure 3. Belgium: Nonfinancial Sector Developments
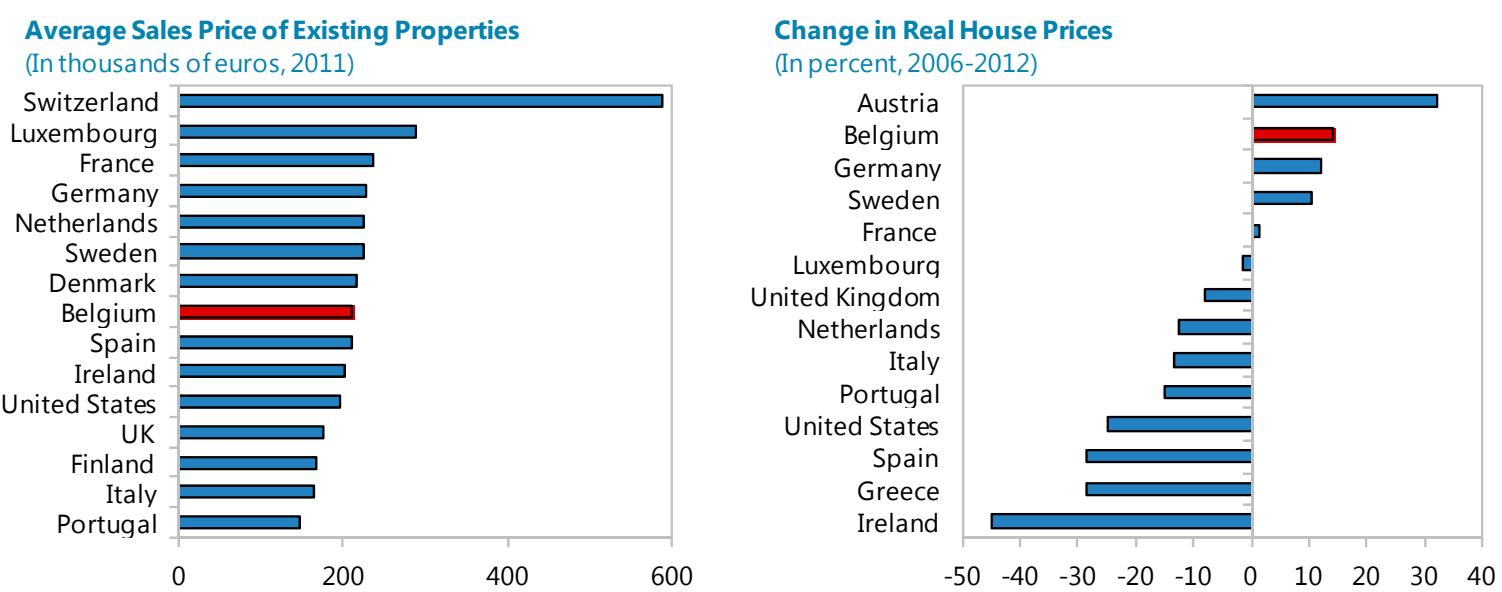

\section{Loan Affordability $1 /$}

(Index, 2012)

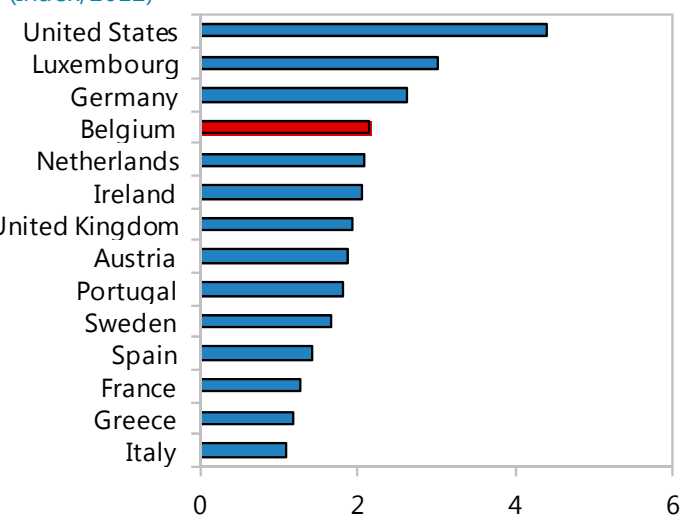

Household Debt

(In percent of disposable income)

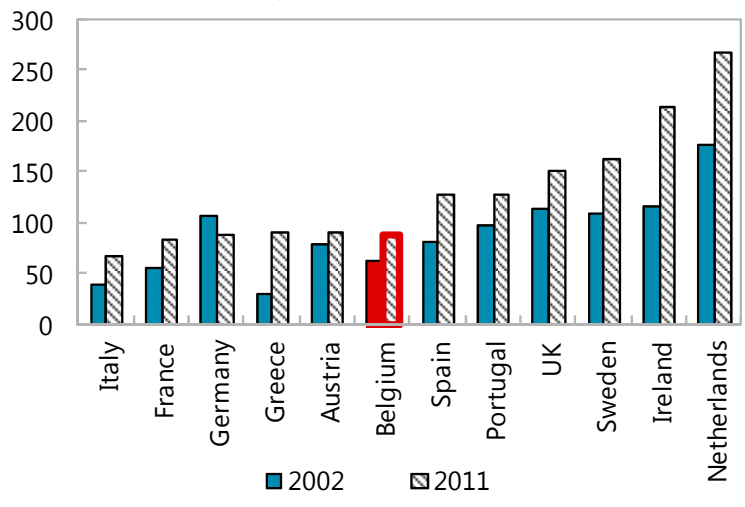

Belgium: Bank Exposure of Real Estate Sector

(In percent of total loans)

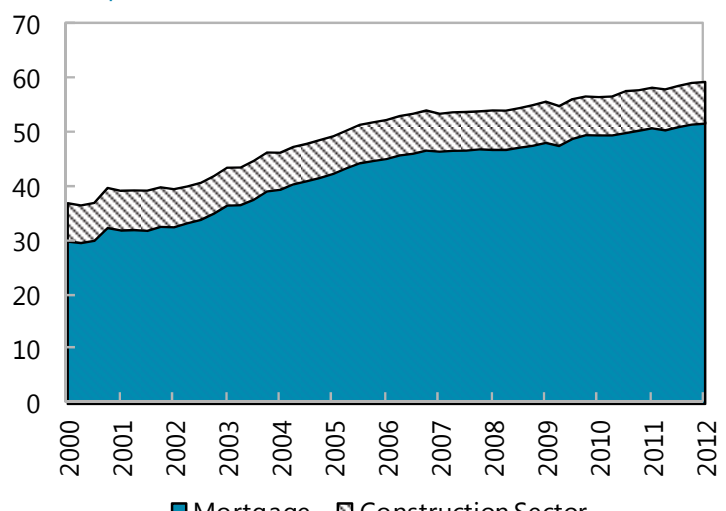

Nonfinancial Corporate Debt 2/

(Average 2008-2011, in percent of GDP)

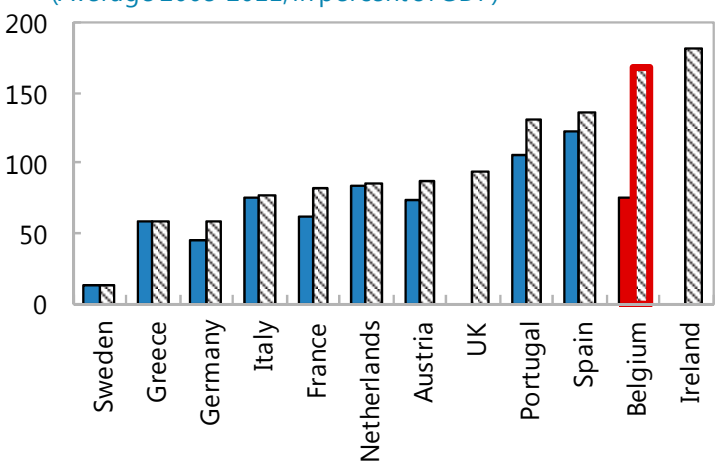

$\square$ Consolidated debt $\mathbf{Q}$ Nonconsolidated debt

Sources: Belgium's Ministry of Economy, OECD, Haver, Global Property Guide, KBC Bank,

Economagic.com, www.numbeo.com, and IMF staff calculations.

1/ Loan Affordability Index is calculated as an inverse of mortgage as percentage of average monthly salary. Larger values indicate more affordable housing.

2 / Consolidated data not available for Ireland or the UK. 
Figure 4. Belgium: Financial Market Indicators
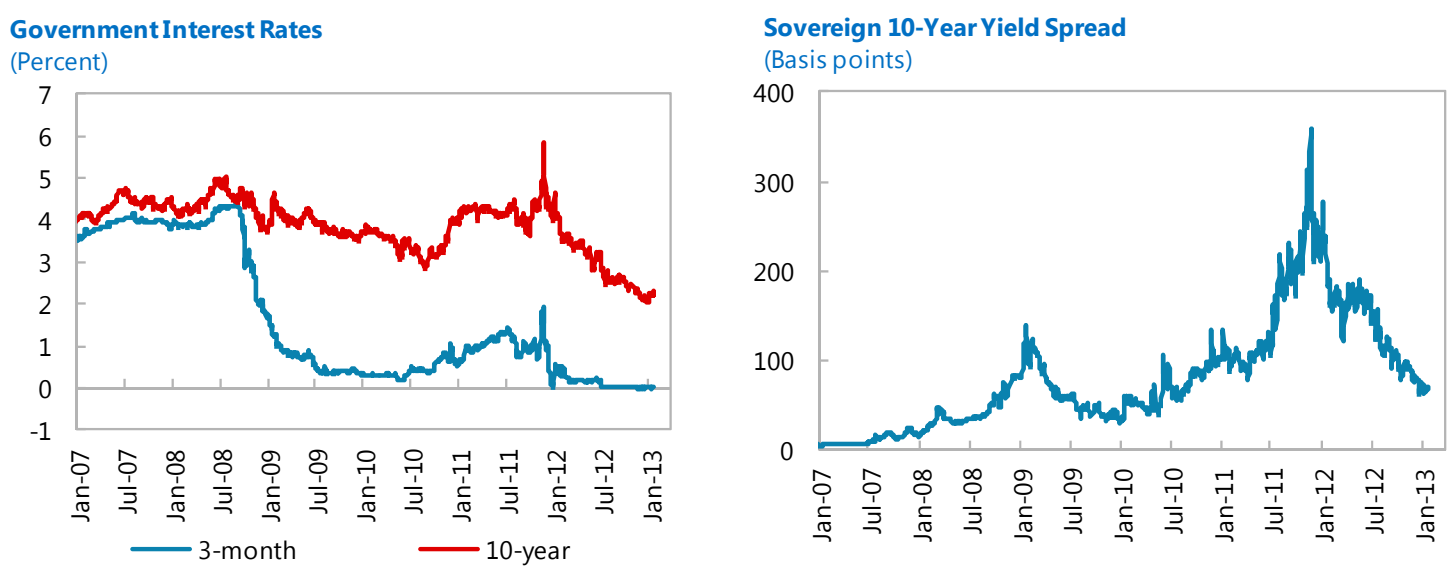

Equities

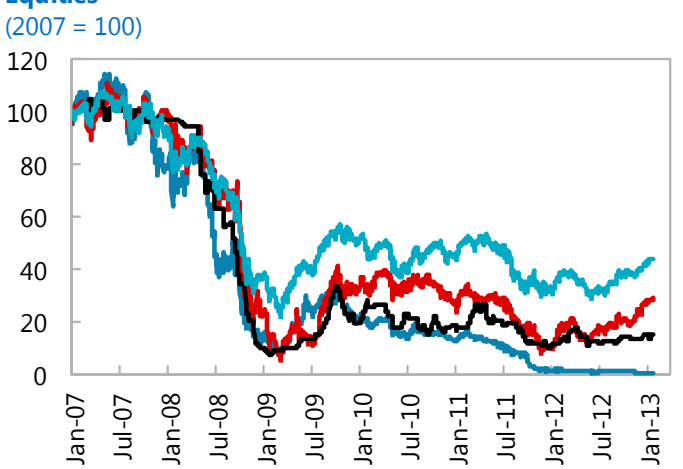

Stock Indices

$(2007=100)$

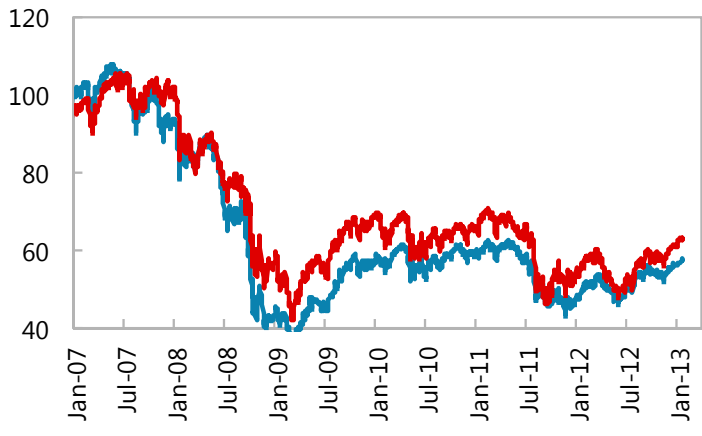

Dexia $\longrightarrow$ KBC $\longrightarrow$ BNP Paribas Fortis — EU 1/
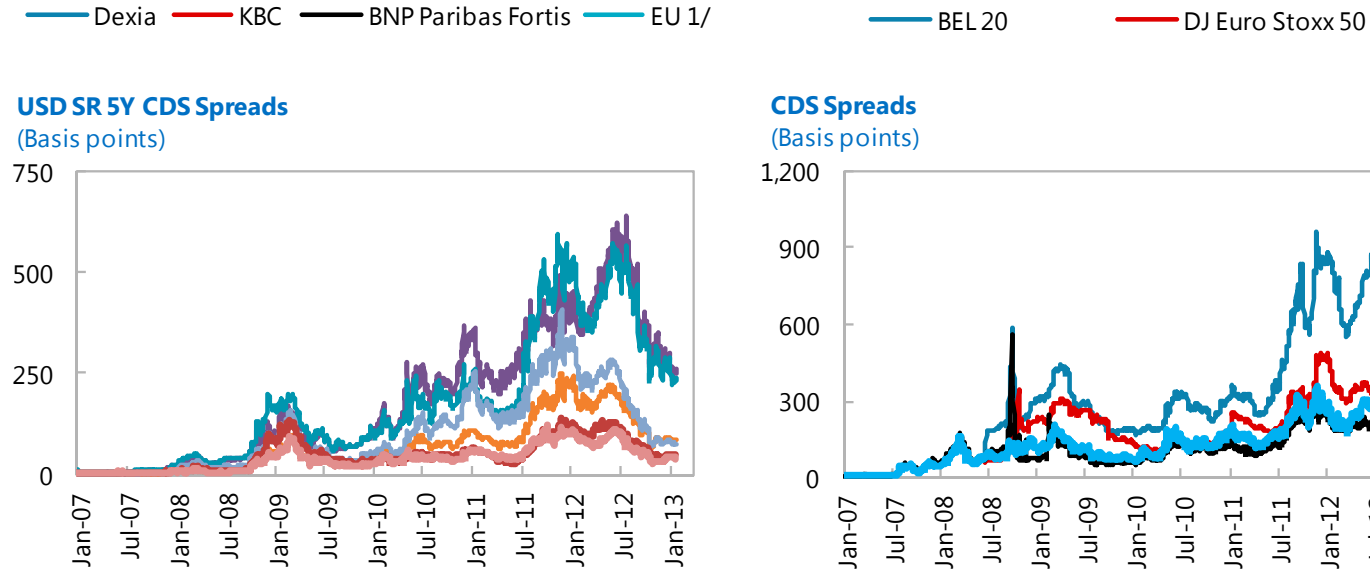

CDS Spreads

(Basis points)

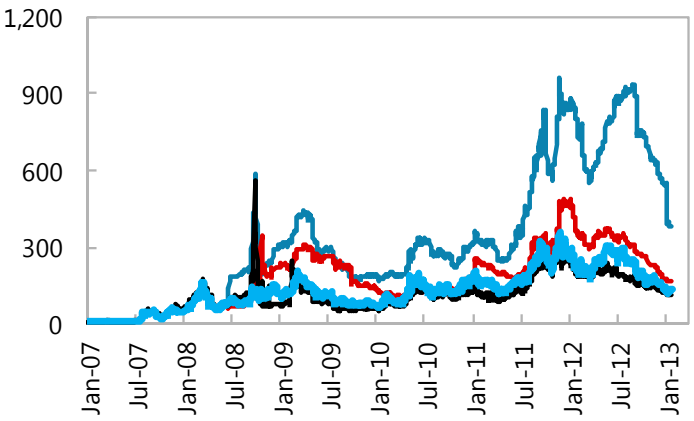

$\longrightarrow$ ESP $\longrightarrow$ ITA $\longrightarrow$ FRA $\longrightarrow$ BEL $\longrightarrow$ NLD $\longrightarrow$ DEU

$\longrightarrow$ Dexia $\longrightarrow$ KBC — BNP Paribas Fortis—Europe 21

Sources: Bloomberg and Thomson Reuters DataStream.

${ }^{1}$ Stock market index compiled by Thomson Reuters Datastream for the share prices of EU financial intermediaries.

2iTraxx Senior Financials index for 5-year credit default swaps for a sample of 25 large European financial institutions. 


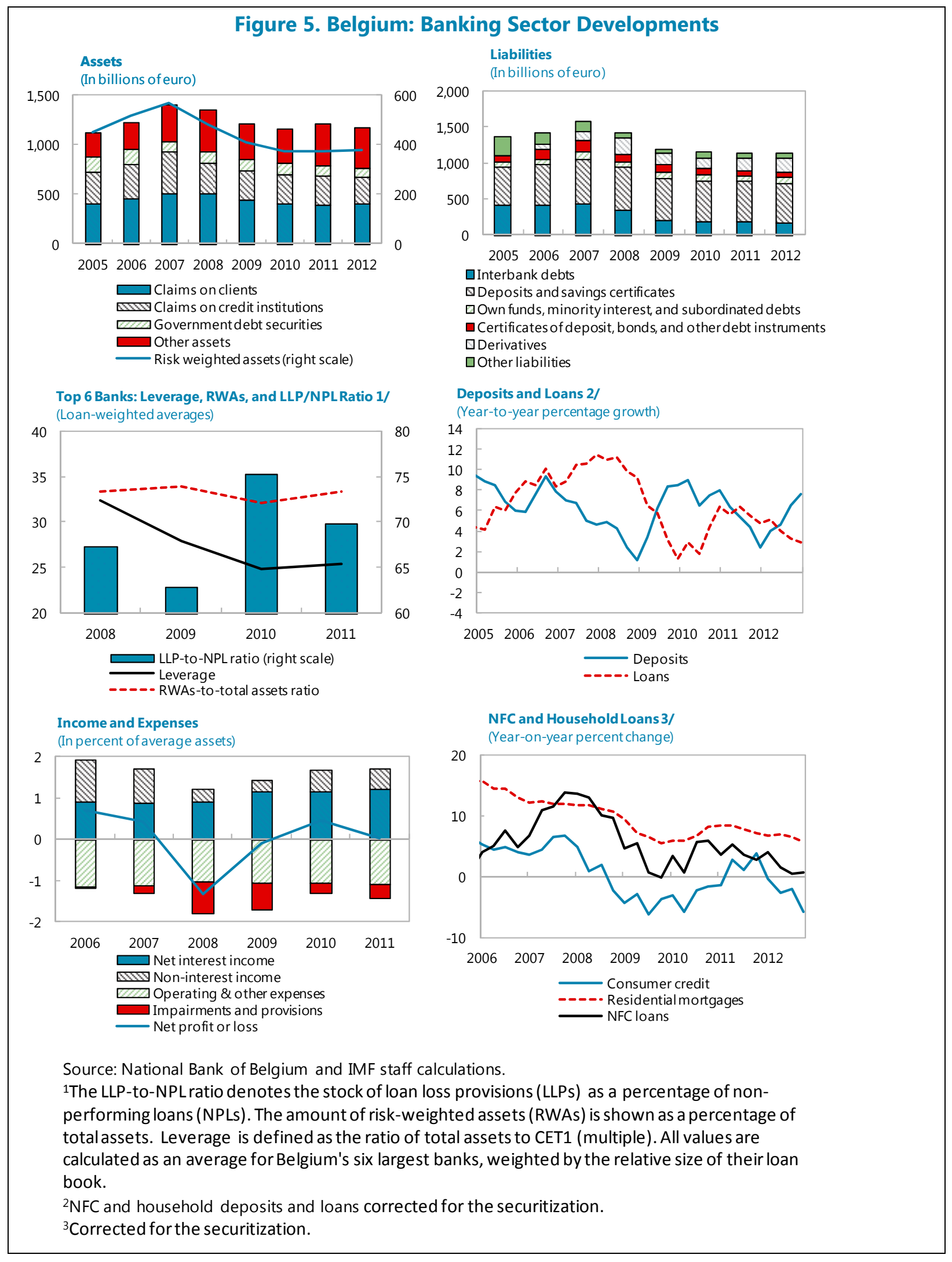




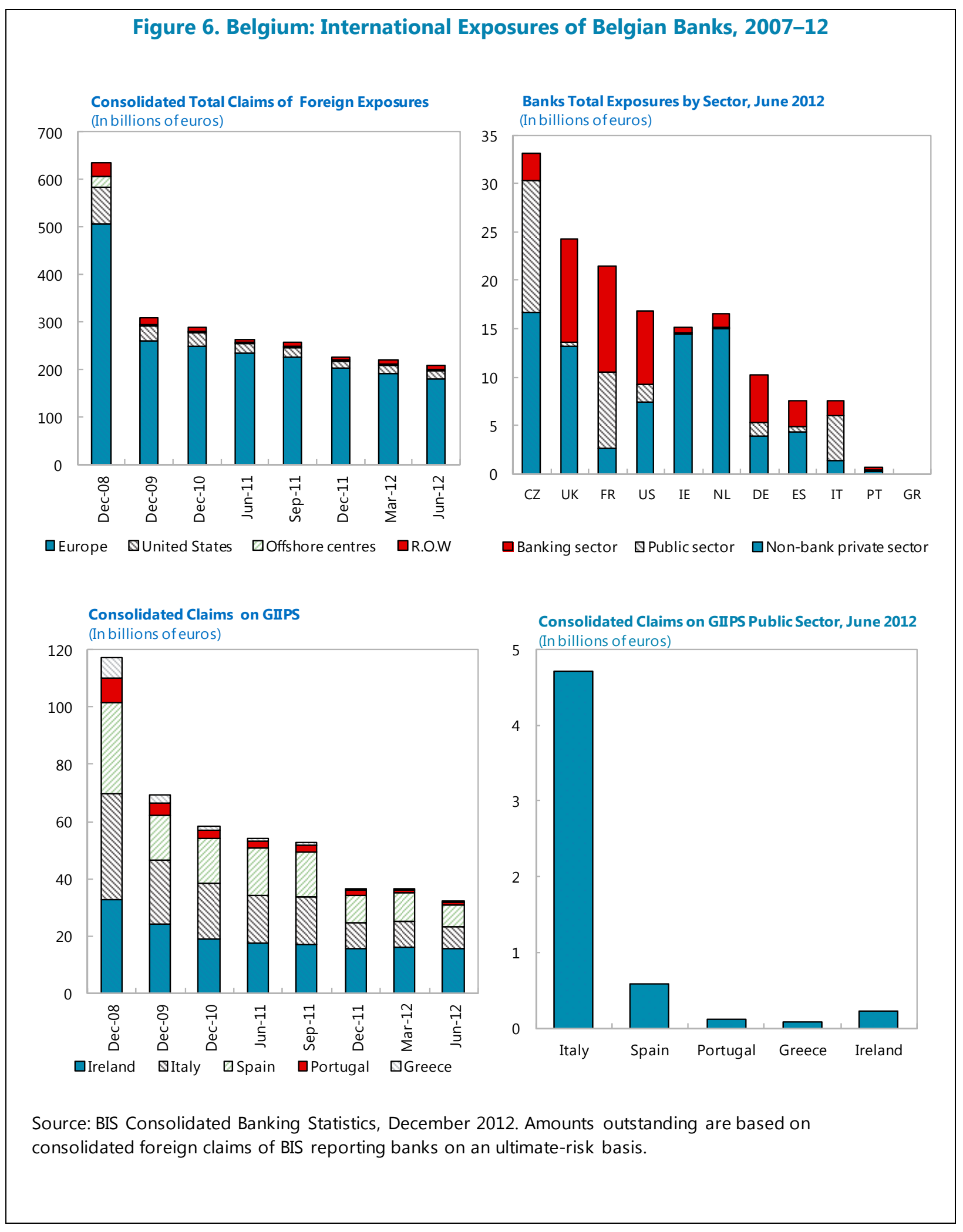




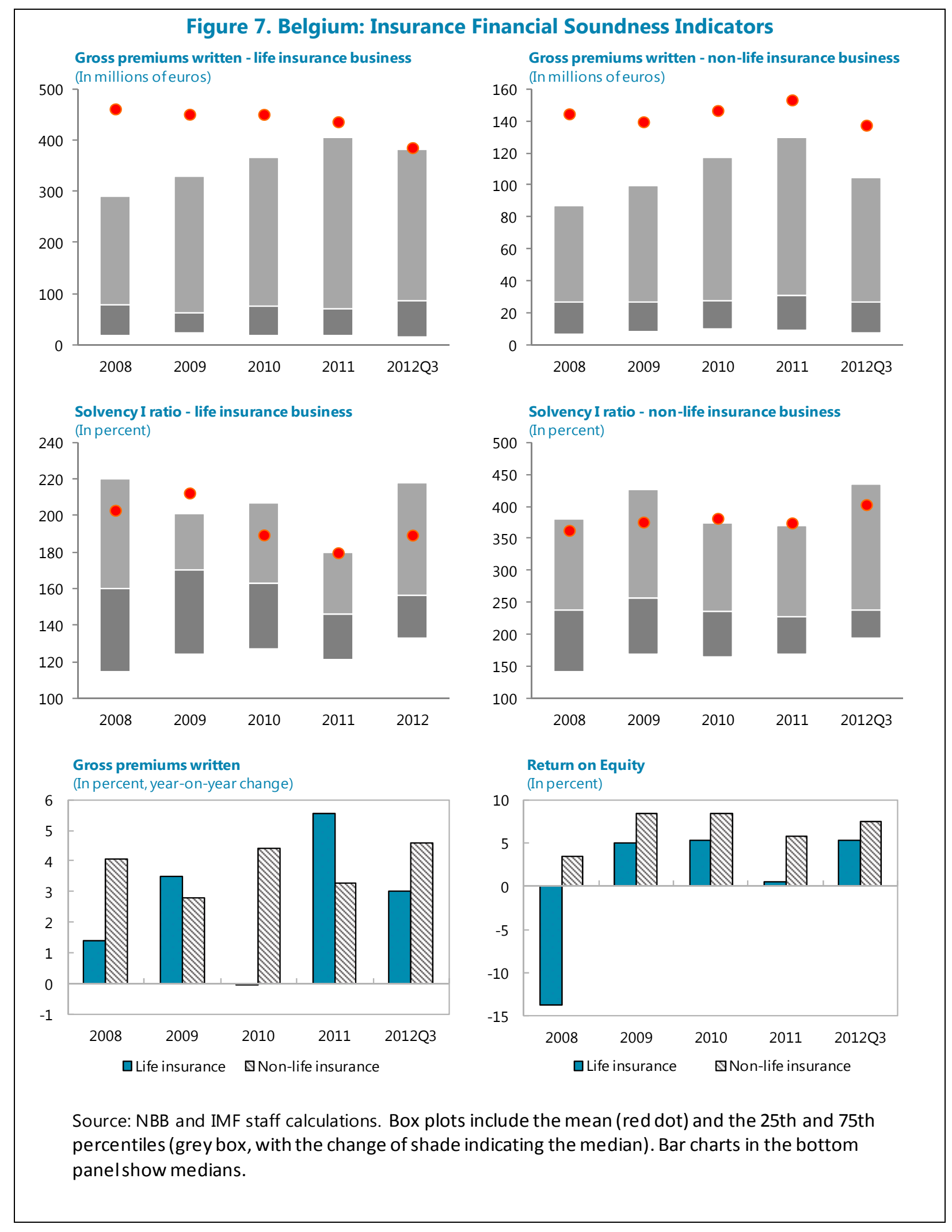


Figure 8. Belgium: Macroeconomic Assumptions Under Different Stress Test Scenarios
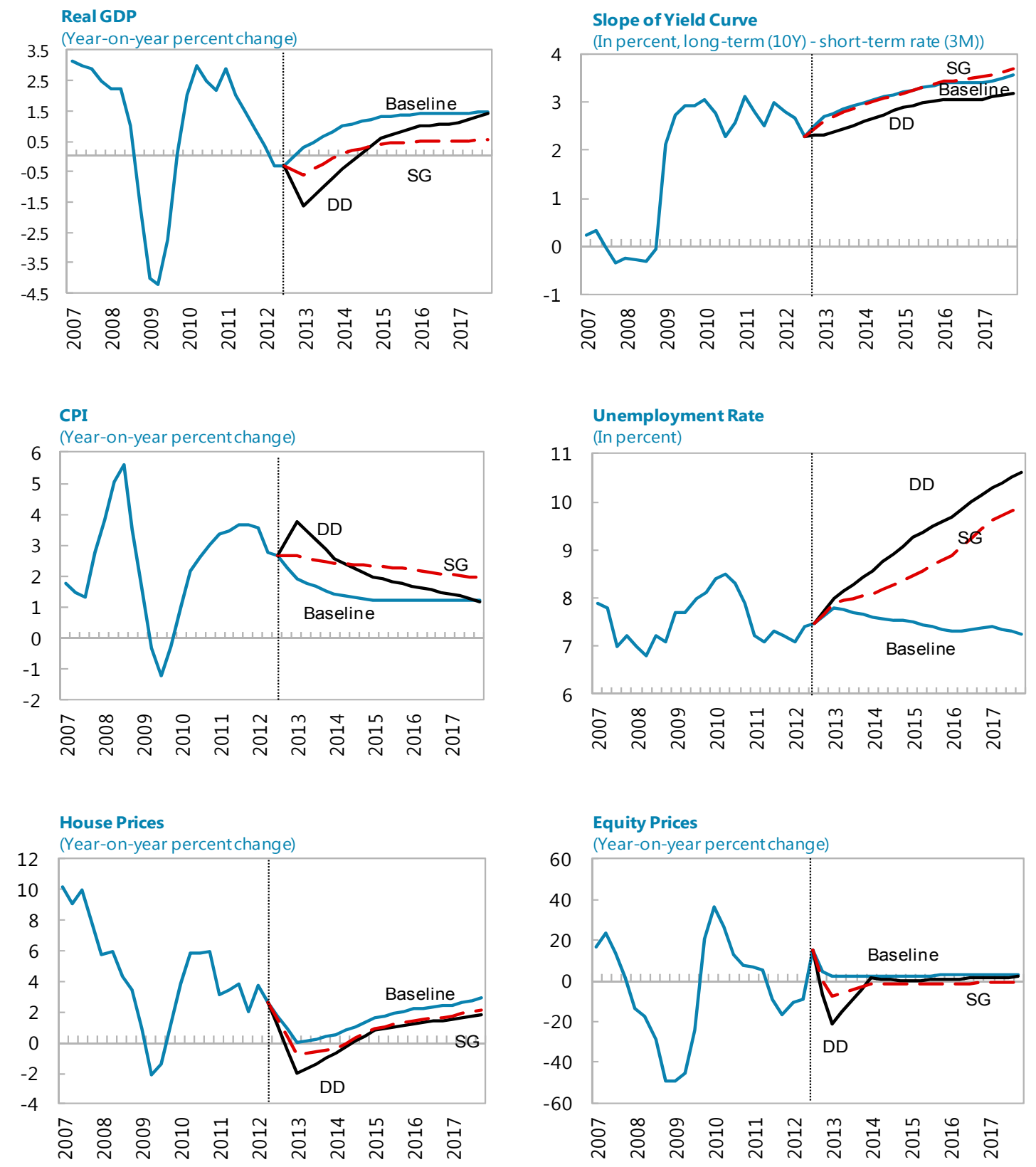

Sources: National Bank of Belgium; and IMF staff estimates.

IMF Baseline (Baseline)

- IMF double dip scenario (DD)

--- IMF slow growth scenario (SG) 


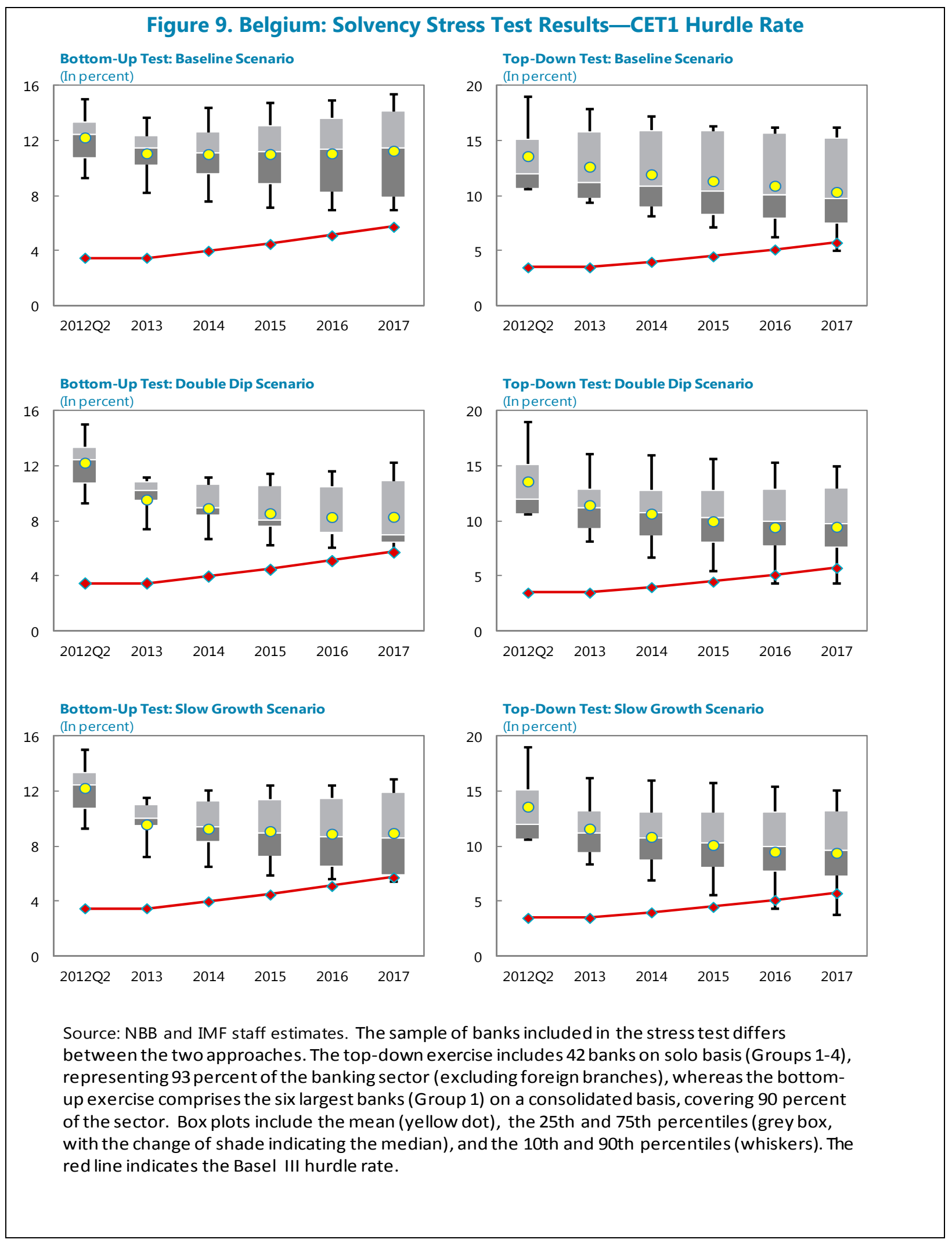


Figure 10. Belgium: Liquidity Indicators and Stress Test Results
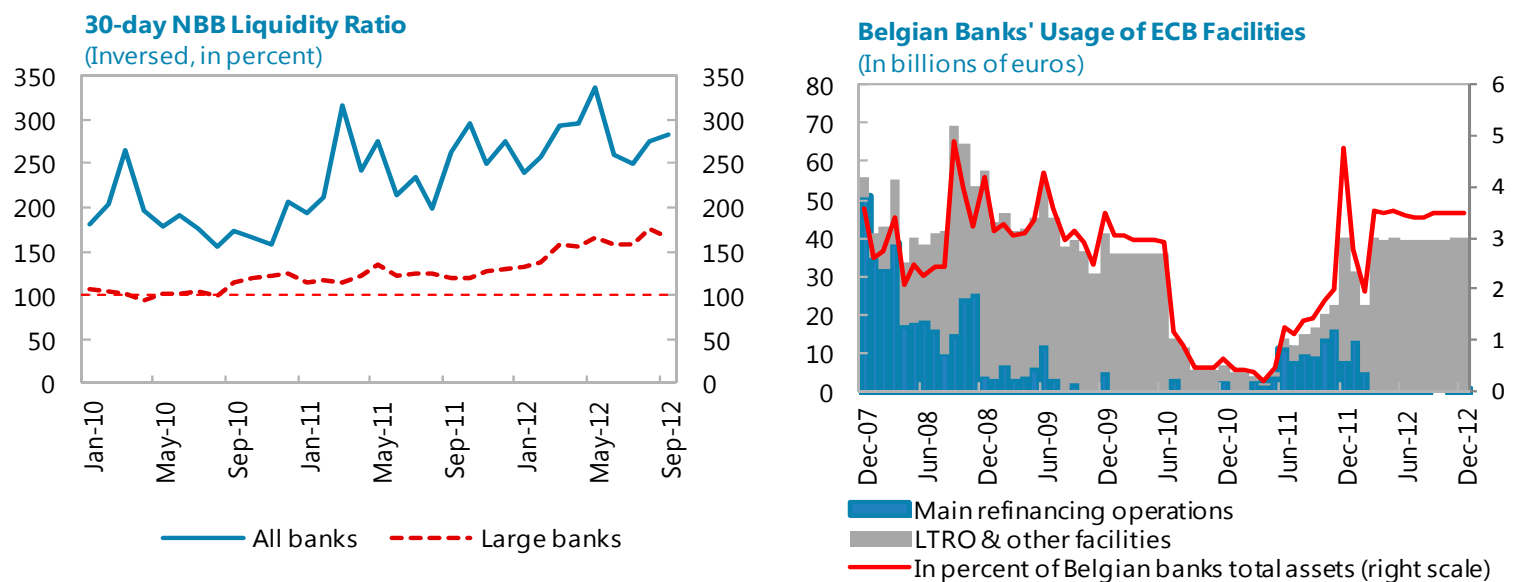

Average Liquidity Coverage Ratio (LCR)
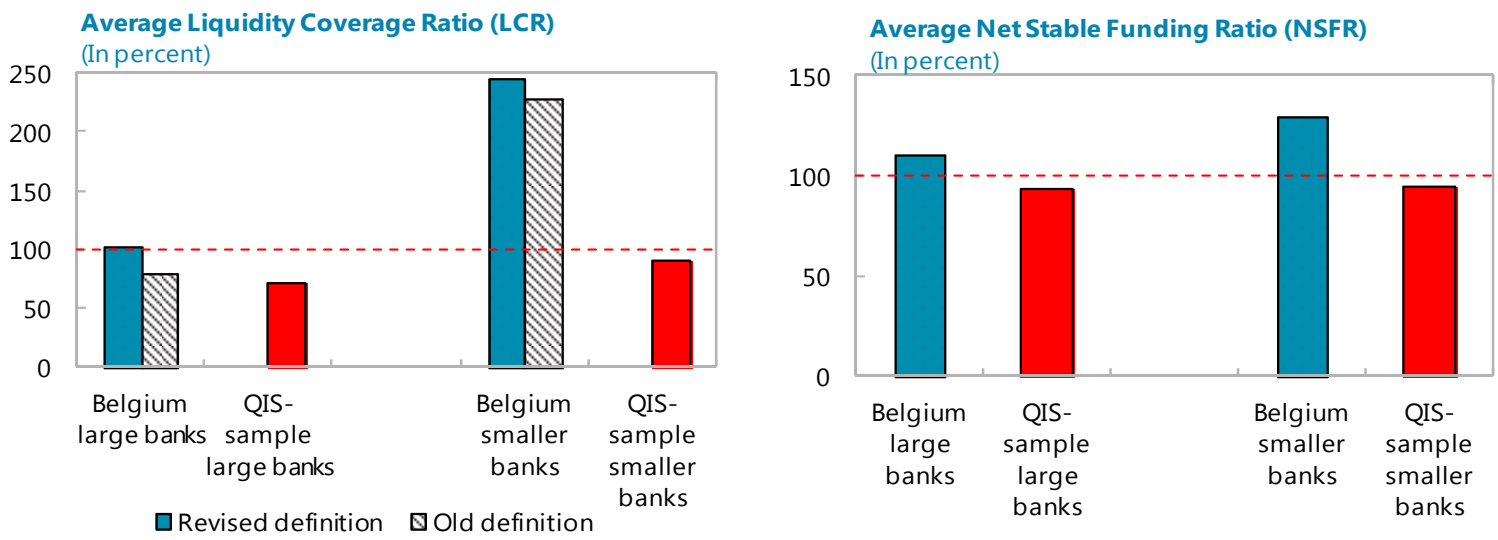

Liquidity Ratios

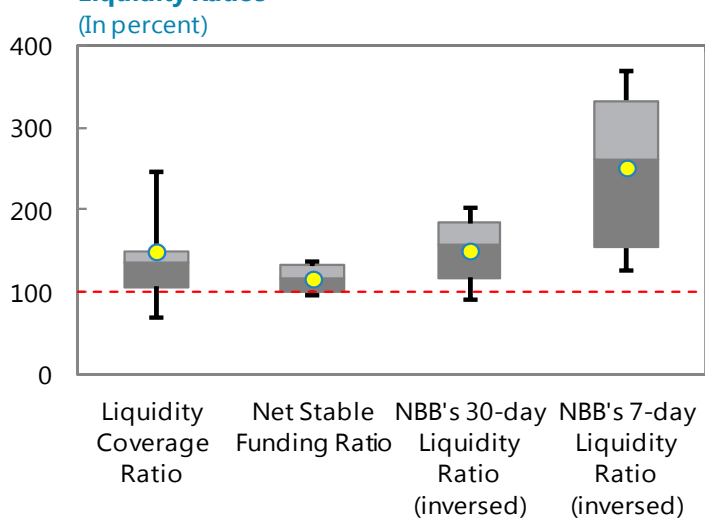

Liquidity Stress Tests on Consolidated Basis (Inversed 30-day NBB ratio, in percent)

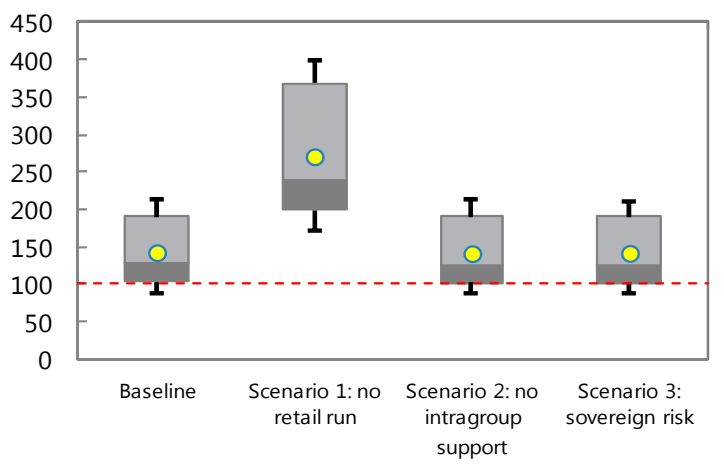

Source: NBB, EBA, and IMF staff calculations. Box plots include the mean (yellow dot), the 25th and 75th percentiles (grey box, with the change of shade indicating the median), and the 10th and 90th percentiles (whiskers). Ratios are capped at 400 percent, both for the calculation of the averages and in the charts. 
Table 2. Belgium: Baseline-Selected Economic Indicators, 2009-17

\begin{tabular}{|c|c|c|c|c|c|c|c|c|c|c|}
\hline & \multirow[b]{2}{*}{2009} & \multirow[b]{2}{*}{2010} & \multirow[b]{2}{*}{2011} & \multirow{2}{*}{$\begin{array}{l}\text { Prel. } \\
2012\end{array}$} & \multicolumn{6}{|c|}{ Projections } \\
\hline & & & & & 2013 & 2014 & 2015 & 2016 & 2017 & 2018 \\
\hline & \multicolumn{10}{|c|}{ (Percentage change from the previous period; unless otherwise indicated) } \\
\hline \multicolumn{11}{|c|}{ 要 } \\
\hline Real GDP & -2.8 & 2.4 & 1.8 & -0.2 & 0.2 & 1.2 & 1.3 & 1.4 & 1.5 & 1.6 \\
\hline Domestic demand & -2.2 & 1.8 & 1.8 & -0.6 & -0.1 & 1.0 & 1.1 & 1.3 & 1.4 & 1.5 \\
\hline Private consumption & 0.6 & 2.7 & 0.2 & -0.6 & 0.0 & 0.9 & 1.1 & 1.4 & 1.5 & 1.6 \\
\hline Public consumption & 1.9 & 0.7 & 0.8 & 0.1 & 0.0 & 0.5 & 0.6 & 0.6 & 0.8 & 0.8 \\
\hline Gross fixed investment & -8.4 & -1.4 & 4.1 & -0.6 & -0.5 & 1.6 & 1.8 & 2.0 & 2.1 & 2.2 \\
\hline Business investment & -10.2 & -3.2 & 8.6 & 0.1 & -0.7 & 1.5 & 1.6 & 1.7 & 1.8 & 1.9 \\
\hline Public investment & 9.7 & -3.1 & 5.3 & 1.5 & -4.1 & -1.0 & 0.4 & 1.0 & 1.6 & 2.0 \\
\hline Dwellings & -8.6 & 3.1 & -5.3 & -3.0 & 1.0 & 2.6 & 2.7 & 2.8 & 2.9 & 3.0 \\
\hline Stockbuilding $1 /$ / & -1.0 & 0.4 & 0.6 & -0.2 & 0.0 & 0.0 & 0.0 & 0.0 & 0.0 & 0.0 \\
\hline Foreign balance 1 / & -0.7 & 0.6 & 0.0 & 0.4 & 0.3 & 0.3 & 0.2 & 0.1 & 0.1 & 0.1 \\
\hline Exports, goods and services & -11.1 & 9.6 & 5.5 & 0.4 & 0.6 & 2.5 & 2.7 & 3.0 & 3.2 & 3.5 \\
\hline Imports, goods and services & -10.6 & 8.9 & 5.6 & -0.1 & 0.3 & 2.2 & 2.6 & 3.0 & 3.2 & 3.5 \\
\hline Household saving ratio (in percent) & 18.1 & 15.2 & 14.1 & 15.1 & 15.7 & 16.1 & 16.4 & 16.5 & 16.7 & 16.7 \\
\hline Potential output growth & 0.9 & 0.8 & 0.8 & 0.8 & 0.8 & 1.0 & 1.1 & 1.2 & 1.4 & 1.4 \\
\hline Output gap (in percent) & -1.8 & -0.2 & 0.7 & -0.2 & -0.9 & -0.7 & -0.5 & -0.4 & -0.2 & 0.0 \\
\hline \multicolumn{11}{|l|}{ Employment } \\
\hline Unemployment rate & 7.8 & 8.2 & 7.2 & 7.6 & 8.0 & 8.1 & 8.1 & 7.8 & 7.6 & 7.4 \\
\hline Employment & -0.2 & 0.7 & 1.4 & 0.2 & -0.2 & 0.4 & 0.7 & 0.8 & 0.9 & 0.9 \\
\hline \multicolumn{11}{|l|}{ Prices } \\
\hline Consumer prices & 0.0 & 2.3 & 3.4 & 2.6 & 1.7 & 1.4 & 1.2 & 1.2 & 1.2 & 1.2 \\
\hline GDP deflator & 1.2 & 2.0 & 2.0 & 2.1 & 1.8 & 1.4 & 1.2 & 1.2 & 1.2 & 1.2 \\
\hline ULC (in whole economy) & 3.8 & -0.3 & 2.7 & 3.6 & 1.2 & 1.3 & 1.2 & 1.2 & 1.2 & 1.2 \\
\hline & \multicolumn{10}{|c|}{ (Percent of GDP; unless otherwise indicated) } \\
\hline \multicolumn{11}{|l|}{ Public finance } \\
\hline Revenue & 48.1 & 48.7 & 49.5 & 50.8 & 51.0 & 51.2 & 51.3 & 51.5 & 51.7 & 51.7 \\
\hline Expenditure & 53.7 & 52.6 & 53.4 & 54.8 & 53.6 & 53.3 & 52.9 & 52.4 & 51.9 & 51.5 \\
\hline General government balance 2/ & -5.6 & -3.8 & -3.7 & -3.9 & -2.5 & -2.0 & -1.5 & -0.8 & -0.1 & 0.3 \\
\hline Structural balance & -3.8 & -3.7 & -4.0 & -3.4 & -2.5 & -1.9 & -1.3 & -0.6 & -0.1 & 0.3 \\
\hline Primary balance & -1.9 & -0.4 & -0.4 & -0.5 & 0.8 & 1.5 & 2.0 & 2.6 & 3.2 & 3.5 \\
\hline General government debt & 95.7 & 95.5 & 97.8 & 99.6 & 100.3 & 99.9 & 99.0 & 97.3 & 94.9 & 92.1 \\
\hline \multicolumn{11}{|l|}{ Balance of payments } \\
\hline Trade balance & 0.5 & 1.0 & -1.2 & -0.7 & -0.6 & -0.3 & -0.1 & 0.2 & 0.4 & 0.7 \\
\hline Current account & -1.4 & 1.9 & -1.1 & -1.4 & -0.7 & -0.3 & 0.1 & 0.5 & 0.9 & 1.2 \\
\hline Terms of Trade (percent change) & 3.5 & -2.0 & -1.4 & -1.7 & -0.1 & 0.2 & 0.2 & 0.2 & 0.1 & 0.1 \\
\hline Exports, goods and services (volume, percent chan & -10.9 & 8.5 & 4.1 & -1.1 & 0.6 & 2.5 & 2.7 & 3.0 & 3.2 & 3.5 \\
\hline Imports, goods and services (volume, percent chan & -11.6 & 7.0 & 3.7 & -1.6 & 0.3 & 2.2 & 2.6 & 3.0 & 3.2 & 3.5 \\
\hline \multicolumn{11}{|l|}{ Memorandum items: } \\
\hline Nominal GDP (billions of euros) & 341 & 356 & 370 & 377 & 384 & 394 & 404 & 415 & 426 & 438 \\
\hline Population (millions) & 10.8 & 10.8 & 11.0 & 11.1 & 11.2 & 11.3 & 11.3 & 11.4 & 11.5 & 11.6 \\
\hline
\end{tabular}

Sources: Data provided by the Belgian authorities, and IMF staff projections.

1/ Contribution to GDP growth.

2/ Defined as in the Excessive Deficit Procedure. 


\begin{tabular}{|c|c|c|c|c|c|c|c|}
\hline & 2006 & 2007 & 2008 & 2009 & 2010 & 2011 & $2012 \mathrm{H1}$ \\
\hline \multicolumn{8}{|l|}{ Banking sector } \\
\hline Number of credit institutions & 105 & 110 & 107 & 104 & 107 & 108 & 109 \\
\hline Domestic & 51 & 52 & 51 & 48 & 48 & 47 & 47 \\
\hline Branches of foreign banks & 54 & 58 & 56 & 56 & 59 & 61 & 62 \\
\hline Total assets (in billions of euros) ${ }^{1}$ & 1,422 & 1,578 & 1,422 & 1,191 & 1,151 & 1,147 & 1,164 \\
\hline of which 4 largest banks & 1,348 & 1,489 & 1,324 & 1,092 & 1,003 & 968 & 973 \\
\hline of which claims on Belgian residents & 411 & 449 & 503 & 483 & 478 & 500 & 547 \\
\hline \multicolumn{8}{|l|}{ Insurance sector } \\
\hline Number of insurance companies & 324 & 314 & 304 & 295 & 292 & 296 & 294 \\
\hline Life & 162 & 157 & 152 & 148 & 147 & 149 & 148 \\
\hline Mixed & 29 & 30 & 30 & 29 & 28 & 26 & 26 \\
\hline Non-life & 23 & 23 & 22 & 23 & 24 & 25 & 25 \\
\hline Reinsurance & 110 & 104 & 100 & 95 & 93 & 96 & 95 \\
\hline Total assets (in billions of euros) $)^{2}$ & 202 & 220 & 224 & 234 & 249 & 257 & 261 \\
\hline \multicolumn{8}{|l|}{ Net premiums written (in billions of euros) ${ }^{2}$} \\
\hline Life & 20 & 22 & 21 & 19 & 19 & 11 & 19 \\
\hline Non-life & 9 & 9 & 10 & 9 & 10 & 10 & 6 \\
\hline \multicolumn{8}{|l|}{ Other financial intermediaries } \\
\hline \multicolumn{8}{|l|}{ Stockbroking firms } \\
\hline Number & 27 & 26 & 23 & 23 & 23 & 22 & 22 \\
\hline Income (in billions of euros) ${ }^{3}$ & 0.3 & 0.4 & 0.3 & 0.3 & 0.3 & 0.2 & 0.1 \\
\hline Total assets (in billions of euros) & 2.3 & 3.1 & 2.7 & 2.3 & 2.4 & 2.0 & 4.2 \\
\hline \multicolumn{8}{|l|}{ Portfolio management companies } \\
\hline Number & 22 & 23 & 26 & 24 & 24 & 20 & 21 \\
\hline Income (in billions of euros) ${ }^{3}$ & 0.1 & 0.1 & 0.1 & 0.0 & 0.0 & 0.0 & 0.0 \\
\hline Assets under management (in billions of euros) & 47 & 49 & 25 & 49 & 62 & 7 & 6 \\
\hline \multicolumn{8}{|c|}{ Management companies of undertakings for collective investment } \\
\hline Number & 6 & 7 & 7 & 7 & 7 & 7 & 7 \\
\hline Income (in billions of euros) ${ }^{3}$ & 1.2 & 1.4 & 1.2 & 0.5 & 0.9 & 0.8 & 0.4 \\
\hline Assets under management (in billions of euros) & 256 & 252 & 193 & 189 & 194 & 178 & 179 \\
\hline \multicolumn{8}{|c|}{ Undertakings for collective investment distributed in Belgium } \\
\hline Number of investment companies & 411 & 410 & 432 & 443 & 478 & 507 & 518 \\
\hline Belgian law & 185 & 179 & 171 & 167 & 166 & 165 & 165 \\
\hline Foreign law & 226 & 231 & 261 & 276 & 312 & 342 & 353 \\
\hline Assets under management (in billions of euros) & 198 & 188 & 128 & 135 & 139 & 115 & 114 \\
\hline \multicolumn{8}{|l|}{ Pension funds } \\
\hline Number & 288 & 277 & 270 & 263 & 251 & 245 & 236 \\
\hline Total assets (in billions of euros) $)^{2}$ & 14 & 15 & 13 & 14 & 16 & 16 & n.a. \\
\hline \multicolumn{8}{|l|}{ Sources: National Bank of Belgium and FSMA. } \\
\hline \multicolumn{8}{|l|}{${ }^{1}$ On consolidated basis. } \\
\hline \multicolumn{8}{|l|}{${ }^{2}$ On company basis. } \\
\hline${ }^{3}$ The figure for June 2012 is non-annualised. & & & & & & & \\
\hline
\end{tabular}


Table 4. Belgium: Financial Sector State Support (2012) (In euro billions, unless indicated otherwise)

\begin{tabular}{lcc} 
& Gross Investments & Guarantees \\
\hline BNP Paribas & 7.3 & $\ldots$ \\
BNP Paribas Fortis & 2.4 & 2.4 \\
Dexia $^{1}$ & 4.9 & 52.0 \\
Belfius & 4.0 & $\ldots$ \\
Ethias & 1.5 & $\ldots$ \\
Royal Park Investment & 0.7 & 4.9 \\
KBC & 7.0 & 9.4 \\
& & \\
Total & 27.8 & 68.7 \\
In percent of 2012 GDP & 7.4 & 18.2 \\
& \\
Memorandum item: & \\
Total recovery & \\
\hline Source: NBB and IMF staff calculations. & 3.5 \\
${ }^{1}$ The full amount of guarantees committed in 2012 are included. \\
${ }^{2}$ Discontinued guarantees and repaid capital investments. \\
\end{tabular}


Table 5. Belgium: Financial Soundness Indicators for the Banking Sector ${ }^{1}$ (In percent unless indicated otherwise)

\begin{tabular}{|c|c|c|c|c|c|c|c|c|}
\hline & 2006 & 2007 & 2008 & 2009 & 2010 & 2011 & 2012 Q2 & 2012 Q3 \\
\hline \multicolumn{9}{|l|}{ Earnings and profitability } \\
\hline Return on assets & 0.7 & 0.4 & -1.3 & -0.1 & 0.5 & 0.0 & 0.1 & 0.2 \\
\hline Return on equity & 22.4 & 13.2 & -36.5 & -2.7 & 10.7 & 0.7 & 2.9 & 4.4 \\
\hline Net interest income to total income & 47.9 & 50.3 & 75.0 & 79.1 & 68.3 & 71.2 & 76.1 & 71.7 \\
\hline Interest margin & 1.0 & 1.1 & 1.0 & 0.8 & 1.2 & 1.2 & 1.4 & 1.3 \\
\hline Average yield on assets & 4.6 & 5.3 & 5.0 & 2.8 & 2.8 & 2.9 & 3.0 & 2.9 \\
\hline Average cost of funding & 3.60 & 4.20 & 4.00 & 2.00 & 1.60 & 1.70 & 1.60 & 1.60 \\
\hline Noninterest income to gross income & 52.1 & 49.5 & 24.9 & 20.9 & 31.7 & 28.8 & 23.9 & 28.3 \\
\hline Of which: Net fee and commission income & 25.1 & 27.9 & 35.1 & 30.1 & 25.6 & 26.8 & 30.8 & 28.8 \\
\hline (Un)realized capital gains booked in P\&L & 14.6 & 14.3 & -19.9 & -14.5 & -0.2 & -3.9 & -6.0 & -0.7 \\
\hline Cost/income ratio & 55.7 & 61.1 & 86.1 & 77.7 & 66.0 & 67.3 & 75.3 & 71.4 \\
\hline \multicolumn{9}{|l|}{ Structure assets } \\
\hline Total assets (in percent of GDP) & 446.0 & 470.0 & 410.5 & 349.2 & 323.2 & 310.2 & 309.0 & 303.4 \\
\hline \multicolumn{9}{|l|}{ Of which (in percent of total assets): } \\
\hline Loans to credit institutions & 20.1 & 20.3 & 15.0 & 13.1 & 17.0 & 15.2 & 13.9 & 12.7 \\
\hline Debt securities & 22.5 & 18.8 & 21.0 & 22.3 & 20.1 & 18.5 & 17.3 & 17.1 \\
\hline Equity instruments & 3.6 & 3.3 & 1.1 & 0.8 & 0.5 & 0.4 & 0.4 & 0.5 \\
\hline Derivatives & 4.5 & 7.6 & 15.7 & 11.3 & 11.6 & 14.6 & 14.5 & 14.4 \\
\hline Loans to customers & 41.6 & 42.2 & 39.1 & 45.0 & 44.0 & 44.4 & 44.3 & 45.1 \\
\hline Of which: Belgian residents (in percent of loans) & 43 & 43 & 53 & 59 & 64 & 70 & 69 & 69 \\
\hline Other EMU residents (in percent of loans) & 29 & 30 & 20 & 19 & 19 & 17 & 17 & 17 \\
\hline Rest of the world (in percent of loans) & 28 & 27 & 28 & 22 & 17 & 13 & 14 & 14 \\
\hline Mortgage loans (in billion euro) & 190 & 208 & 132 & 158 & 179 & 184 & 185 & 185 \\
\hline Consumer loans (in billion euro) & 15 & 17 & 17 & 17 & 24 & 23 & 24 & 24 \\
\hline Term loans (in percent of loans) & 46.1 & 40.1 & 47.8 & 44.0 & 42.3 & 40.0 & 38.9 & 39.2 \\
\hline Reverse repo operations (in percent of loans) & 16.9 & 10.5 & 10.1 & 7.3 & 7.3 & 4.2 & 4.4 & 4.9 \\
\hline \multicolumn{9}{|l|}{ Funding and liquidity (in percent of total assets) } \\
\hline Debts to credit institutions & 29.2 & 27.4 & 19.4 & 14.1 & 15.4 & 11.2 & 11.6 & 10.8 \\
\hline Bank bonds and other debt securities & 11.2 & 11.3 & 8.7 & 12.6 & 10.9 & 8.8 & 9.4 & 9.8 \\
\hline Customer deposits & 39.1 & 37.9 & 40.2 & 46.8 & 46.0 & 46.5 & 46.4 & 46.4 \\
\hline Of which: Sight deposits ${ }^{2}$ & 11.1 & 11.8 & 10.9 & 13.2 & 13.7 & 12.6 & 13.5 & 14.0 \\
\hline Saving deposits ${ }^{2}$ & 10.2 & 8.5 & 9.2 & 14.1 & 16.6 & 16.8 & 17.4 & 17.9 \\
\hline Term deposits ${ }^{2}$ & 10.6 & 11.5 & 11.7 & 8.9 & 8.5 & 9.6 & 9.0 & 8.9 \\
\hline Retail deposits & 20.4 & 17.8 & 18.2 & 23.8 & 26.1 & 26.5 & 27.1 & 27.8 \\
\hline Repo's & 4.2 & 3.5 & 6.4 & 7.1 & 5.0 & 5.2 & 5.0 & 3.8 \\
\hline Liquid assets ${ }^{3}$ & 27.0 & 24.0 & 23.0 & 32.0 & 31.0 & 32.0 & 35.1 & $\ldots$ \\
\hline \multicolumn{9}{|l|}{ Asset quality } \\
\hline \multicolumn{9}{|l|}{ Sectoral distribution of loans (in percent of total assets) } \\
\hline Credit institutions & 20.1 & 20.3 & 15.0 & 13.1 & 17.0 & 15.2 & 13.9 & 12.7 \\
\hline Corporate & 18.3 & 19.9 & 20.5 & 20.5 & 17.2 & 16.4 & 15.6 & 15.7 \\
\hline Retail & 18.3 & 17.5 & 14.6 & 19.9 & 22.1 & 22.9 & 23.7 & 24.1 \\
\hline Central governments & 0.8 & 1.0 & 0.9 & 1.2 & 1.0 & 0.8 & 0.7 & 0.8 \\
\hline Non-credit institutions & 4.1 & 3.8 & 3.1 & 3.4 & 3.8 & 4.3 & 4.3 & 4.5 \\
\hline Non-performing loans (NPL) as percent of gross loans ${ }^{3}$ & 1.7 & 1.4 & 1.7 & 2.7 & 2.8 & 3.2 & 3.2 & 3.2 \\
\hline Provisions and write-offs as percent of NPL ${ }^{3}$ & 51 & 41 & 67 & 51 & 53 & 49 & 51 & 53 \\
\hline \multicolumn{9}{|l|}{ Capital adequacy } \\
\hline Regulatory capital to risk-weighted assets & 11.9 & 11.2 & 16.2 & 17.3 & 19.3 & 18.5 & 17.5 & 17.9 \\
\hline Regulatory Tier 1 capital to risk-weighted assets & 8.7 & 12.1 & 11.3 & 13.2 & 15.5 & 15.1 & 14.8 & 15.4 \\
\hline Capital to assets & 3.3 & 4.1 & 3.3 & 4.5 & 5.0 & 4.6 & 4.8 & 5.2 \\
\hline NPL net of provisions as percent of Tier 1 capital $^{3}$ & 10.9 & 9.2 & 6.5 & 13.8 & 12.2 & 14.2 & 13.9 & 13.3 \\
\hline Net open position in foreign exchange to capital & 5.0 & 3.0 & 7.0 & 5.0 & 4.0 & 5.0 & 2.8 & $\ldots$ \\
\hline \multicolumn{9}{|l|}{ Sources: National Bank of Belgium. } \\
\hline \multicolumn{9}{|c|}{${ }^{1}$ Consolidated data. Data are based on the IAS/IFRS reporting scheme. } \\
\hline \multicolumn{9}{|l|}{${ }^{2}$ Deposits booked at amortized cost only. } \\
\hline${ }^{3}$ Unconsolidated data. & & & & & & & & \\
\hline
\end{tabular}




\section{Appendix I. Belgian Covered Bonds and Financial Stability Considerations}

\section{The global financial crisis led to a fundamental re-assessment of funding sources in}

the banking sector. During periods of market stress, covered bonds provided a funding backstop, albeit mainly for investment-grade banks (rated "BBB-/Baa3" and better), at a time when many markets were effectively closed. The high price of wholesale unsecured funding has also made these instruments more attractive. In Belgian context, covered bonds may allow a reduction in banks' reliance on deposits, lower rollover risk, and facilitate a gradual scaling back of refinancing operations with the ECB. Covered bonds may also reduce default probabilities and deliver cost-efficient funding with longer maturities to reverse the recent increase of assetliability mismatch.

\section{Recent regulatory developments-actual and potential-further support the trend} toward post-crisis prominence of covered bonds. ${ }^{1}$ Covered bonds rated "AA-/Aa3" or higher will count toward the LCR under the Basel III framework while securitizations are excluded. Also, Solvency II assigns a lower capital charge for covered bonds compared to other nongovernment and/or unsecured assets. Furthermore, resolution tools such as 'bail in' do not apply to covered bonds.

3. The NBB will approve each structure, allowing the supervisor to monitor the build-up of total encumbrance of banks' balance sheets. The NBB will also maintain oversight of the integrity of covered bond structures ensuring that the features of such instruments are properly disclosed to the investors.

\footnotetext{
${ }^{1}$ Jobst, Andreas and John Kiff, 2011, "Financial Sector Assessment Program Update -Germany: Technical Note on the Future of German Mortgage-Backed Covered Bond (Pfandbrief) and Securitization Markets," Technical Note, IMF Country Report No. 11/369, December (Washington, D.C.: International Monetary Fund), available at http://www.imf.org/external/pubs/ft/scr/2011/cr11369.pdf.
} 
The Belgian Covered Bond Framework

\begin{tabular}{|c|c|c|c|c|}
\hline \multirow{2}{*}{$\begin{array}{l}\text { National Bank of } \\
\text { Belgium (NBB) }\end{array}$} & Regular Monitoring & & & \\
\hline & & & & \\
\hline \multirow{2}{*}{$\begin{array}{l}\text { Legal Framework } \\
\text { (Pandbrieven Act) }\end{array}$} & \multicolumn{2}{|l|}{ 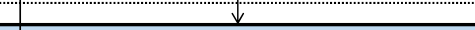 } & & \\
\hline & \multicolumn{2}{|c|}{$\begin{array}{l}\text { Issuing Bank } \\
\text { (any bank with a license from the NBB) }\end{array}$} & Issuance & \\
\hline \multirow{2}{*}{$\begin{array}{c}\text { Cover Pool } \\
\text { Administrator } \\
\text { (approved by NBB in case } \\
\text { of issuer insolvency) }\end{array}$} & \multirow[b]{2}{*}{$\begin{array}{c}\text { Cover Pool } \\
\text { (collateral assets) }\end{array}$} & Covered Bonds & & Investors \\
\hline & & $\begin{array}{l}\text { Senior } \\
\text { Unsecured } \\
\text { Liabilities }\end{array}$ & & \\
\hline \multirow[t]{2}{*}{ Cover Pool Monitor } & Others Assets & $\begin{array}{c}\text { Subordinated } \\
\text { Liabilities }\end{array}$ & & \\
\hline & Cash and Securities & $\begin{array}{l}\text { Shareholder's } \\
\text { Funds }\end{array}$ & & \\
\hline
\end{tabular}

\section{The completed legal framework for the issuance of covered bonds will open up a} new source of secured funding. ${ }^{2}$ Ratings agencies and the markets have responded positively to this development. The legislation gives investors direct recourse to both the segregated assets in the covered pool and also to the other assets of the issuing bank (general estate). Two Belgian banks have issued covered bonds under the new legal framework. Both placements have been rated "Aaa/AAA" by Moody's and Fitch and trade at prices just below the Belgian government bonds but significantly higher than comparable secured debt issued by other European financials (Figure 1.2). Banks have been one of the most active investors, accounting, for example, for 48 percent of the initial KBC placement. From a systemic perspective, the relatively large participation by banks in covered bond placements increases interconnectedness across the sector, potentially increasing risks to financial stability.

\footnotetext{
${ }^{2}$ Covered bonds are on-balance sheet debt obligations secured by a dedicated reference (or "cover") portfolio of assets, with the issuer being fully liable for all interest and principal payments. In the case of Belgian covered bonds, all obligations related to the bonds are backed by an exclusive claim on the cover pool that is recorded in the cover register.
} 
Secondary Market Pricing of Belgian Covered Bonds

Covered Bonds OAS Spreads: Belgium/Euro

(In basis points)

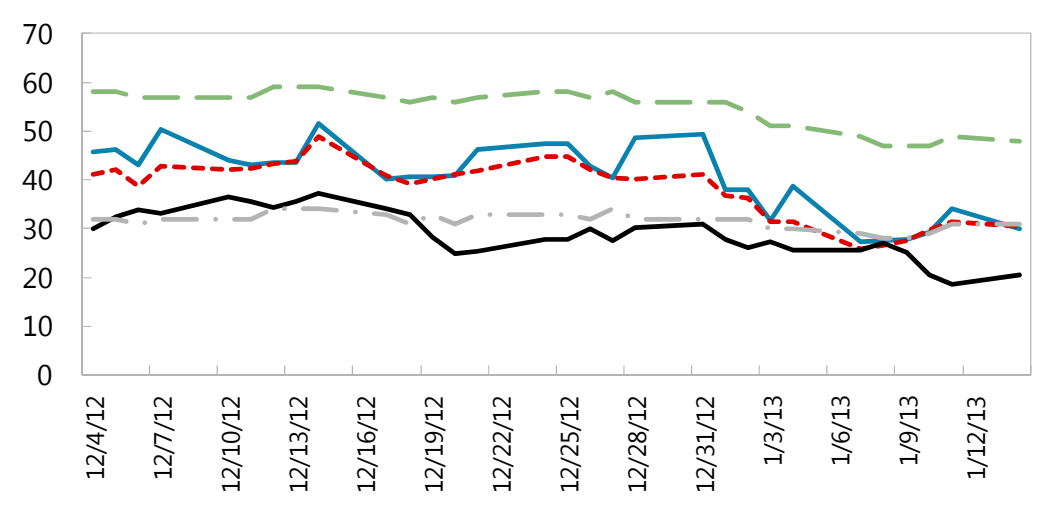

- Belfius

- Sovereign

$--\cdot K B C$

- German Covered Bond Index

Source: Bloomberg

\section{Belgium: 5-Year CDS}

(In basis points)

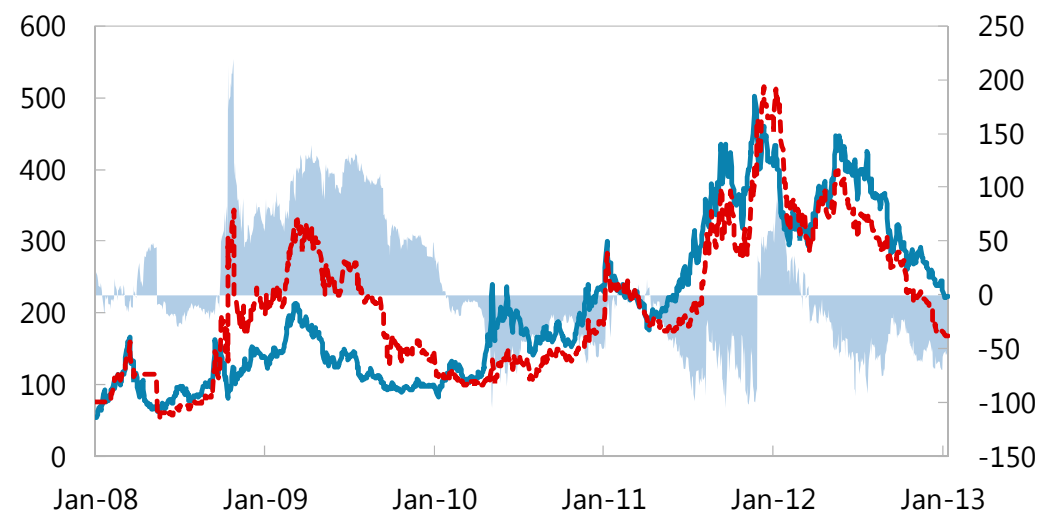

Spread: Belgium financials - Euro area (right scale) —Euro area - - Belgium financials

Sources: Markit, Bloomberg, and IMF staff.

5. To mitigate the risk of structural subordination, the legislation caps the issuance of covered bonds to eight percent of the total assets of the issuing credit institution. ${ }^{3}$ In the event

${ }^{3}$ The implied structural subordination resulting from the encumbrance of high-quality assets could be prejudicial to unsecured creditors' (including depositors and deposit insurers) interest by reducing the debt recovery value of their credit claims. 
of failure, an encumbrance limit mitigates the risk of the issuer's inability to satisfy the claims from unsecured creditors, including depositors. To the extent that covered bond funding replaces unsecured funding, the effectiveness of bail-in as a bank resolution tool will be adversely impacted. Overall, however, capping the covered bond issuance benefits both covered bond holders and unsecured creditors. These limits do not only preserve the economic value of full recourse of covered bond investor but also reduce the risk of rising cover pool dilution should covered bond issuance increase faster than total liabilities and/or the credit quality of unencumbered assets on the balance sheet decline. Moreover, requiring banks to regularly disclose asset encumbrance details such as amounts and overcollateralization, including that relating to dedicated subsidiaries, should rank high on the agenda of policymakers. ${ }^{4}$

\section{Covered bond legislation in other countries imposes similar caps on issuance. While} the majority of EU countries have eschewed this option, some countries have either already adopted encumbrance limits as part of their statutory frameworks or considering their adoption (Table 1.1).

\footnotetext{
${ }^{4}$ Also useful would be information related contingency plans in the event that encumbrance levels turn out to be substantially larger than estimated.
} 
Table 1.1. Covered Bond Legislation in Selected Countries.

\begin{tabular}{ccc}
\hline Country & Year of Introduction/Amendment & Encumbrance Limit \\
\hline Australia & 2011 & Yes \\
Belgium & 2011 & Yes \\
Canada ${ }^{1}$ & 2007 (amendments introduced in 2011) & Yes \\
Denmark & 1795 (amended 2007) & No \\
France & 1999 & No \\
Germany & 1769 (amended 2005, revised 2010) & No \\
Italy & 2005 & Yes \\
Netherlands & 2008 & Case-by-case \\
South Korea & 2009 & No \\
Spain & 2003 & No \\
United & 2008 (amendments introduced in 2011) & Case-by-case \\
Kingdom & & \\
United States ${ }^{2}$ & Draft legislation introduced in 2011 & No \\
\hline
\end{tabular}

Source: Kiff, Surti, and Jobst (2011) and IMF staff. ${ }^{3}$

${ }^{1}$ OSFI applies a limit on issuance but is unclear whether it remain in place after the establishment of a statutory framework;

${ }^{2}$ The FDIC does apply an asset encumbrance limit, which will cease once the draft legislation has passed the U.S. Congress.

${ }^{3}$ Kiff, John, Surti, Jay and Andreas Jobst, 2011, "Covered Bonds and Asset Encumbrance," ECBC Fact Book2011, European Covered Bond Council, pp. 77-80. 


\section{Appendix II. Main Recommendations of the 2006 FSAP}

\begin{tabular}{|c|c|}
\hline Recommendation & Status \\
\hline $\begin{array}{l}\text { Soundness, short-term } \\
\text { vulnerabilities, and } \\
\text { supervisory issues }\end{array}$ & \\
\hline $\begin{array}{l}\text { Establish an effective } \\
\text { mechanism for } \\
\text { consolidated supervision } \\
\text { and organize the } \\
\text { supervisory structure and } \\
\text { approach so as to meet the } \\
\text { special challenges posed by } \\
\text { the bancassurance } \\
\text { conglomerates, given their } \\
\text { systemic importance. }\end{array}$ & $\begin{array}{l}\text { Consolidated supervision is the responsibility of the NBB under the new model } \\
\text { of regulation. The framework for conglomerate regulation is set by the EU; a } \\
\text { new Directive expected to be transposed into Belgian law in the coming year. } \\
\text { A more comprehensive approach to the supervision of financial conglomerates } \\
\text { remains work in progress, with uniform application of governance } \\
\text { requirements and certain supervisory tools related to the monitoring of } \\
\text { multiple leveraging, group-wide and intragroup risks reporting yet to be } \\
\text { developed. }\end{array}$ \\
\hline $\begin{array}{l}\text { Address, as a priority, } \\
\text { identified weaknesses in the } \\
\text { supervision of the insurance } \\
\text { sector by expeditiously } \\
\text { upgrading insurance } \\
\text { supervision and regulation, } \\
\text { and intensifying the } \\
\text { monitoring of insurance } \\
\text { companies. }\end{array}$ & $\begin{array}{l}\text { Prudential supervision of insurers is now the responsibility of the NBB. Since } \\
2006 \text { various initiatives have been taken to strengthen supervision, including } \\
\text { reorganizing and enhancing on-site and off-site supervision. Enhanced } \\
\text { regulations on governance, risk management, internal controls and } \\
\text { outsourcing have also been put in place. Regular horizontal vulnerability } \\
\text { analyses of the sector are also performed, complementing micro-prudential } \\
\text { supervision. }\end{array}$ \\
\hline $\begin{array}{l}\text { Establish an overarching } \\
\text { corporate governance } \\
\text { framework for the financial } \\
\text { sector. }\end{array}$ & $\begin{array}{l}\text { The NBB has worked to make governance a theme of cross-sectoral } \\
\text { supervision. New rules were adopted in } 2007 \text { and } 2008 \text { and a circular on } \\
\text { internal governance produced in } 2007 \text {. Governance is actively considered as } \\
\text { part of supervision, connected with an assessment of firm and group-wide risk } \\
\text { management and internal controls. However, BCP assessment highlighted the } \\
\text { shortcomings in the framework governing bank Boards' oversight of risk } \\
\text { management. The ICP assessment noted that the corporate governance } \\
\text { framework could be enhanced by establishing clearer and explicit supervisory } \\
\text { expectation on the duties for directors to act in a manner that would not } \\
\text { compromise the interests of an insurer and policyholders, particularly in a } \\
\text { group context. }\end{array}$ \\
\hline $\begin{array}{l}\text { Perform stress tests in a } \\
\text { more systematic and } \\
\text { regular way and use the } \\
\text { results to inform the } \\
\text { Financial Stability } \\
\text { Committee (FSC) } \\
\text { discussions. }\end{array}$ & $\begin{array}{l}\text { Institutions are required to undertake both firm-wide and risk-specific stress } \\
\text { tests (under ICAAP and Pillar II guidance), which have yet to be integrated into } \\
\text { a system-wide capital assessment. The NBB also conducts 'regulatory' stress } \\
\text { tests, of which only liquidity risk is assessed at regular frequency. } \\
\text { Macroprudential stress testing has yet to be embedded into both the financial } \\
\text { stability analysis and the supervisory process; however, business model reviews } \\
\text { have already helped establish greater integration of risk analysis and } \\
\text { supervision. }\end{array}$ \\
\hline $\begin{array}{l}\text { Continue to place emphasis } \\
\text { on liquidity management at } \\
\text { the bank and group level } \\
\text { for bancassurance } \\
\text { conglomerates, and provide } \\
\text { explicit guidelines for banks } \\
\text { on liquidity management to } \\
\text { complement the current }\end{array}$ & $\begin{array}{l}\text { In 2006, the authorities introduced a liquidity risk approach, including } \\
\text { qualitative requirements and a reporting scheme. In response to the crisis, the } \\
\text { authorities have introduced, after a two years observation period, a binding } \\
\text { "NBB Liquidity Ratio" in January } 2011 \text { and introduced a new limit for banks on } \\
\text { intragroup exposures. The reconciliation of the national approach with the } \\
\text { Basel III liquidity risk framework under CRD IV will be critical to maintain } \\
\text { regulatory consistency (especially for institutions with significant cross-border } \\
\text { activities). Implementing the agreed approach to Basel III liquidity ratios in }\end{array}$ \\
\hline
\end{tabular}




\begin{tabular}{|c|c|}
\hline Recommendation & Status \\
\hline informal discussions. & $\begin{array}{l}\text { CRD IV, as well as of the Joint Forum principles for liquidity supervision at the } \\
\text { level of financial conglomerates will be the next steps. The NBB envisages that } \\
\text { banks maintain adequate liquidity buffers during the transition phase before } \\
\text { the full introduction of the LCR at the European level. }\end{array}$ \\
\hline $\begin{array}{l}\text { Enhance the resources and } \\
\text { capacity focused on the } \\
\text { oversight and prudential } \\
\text { supervision of the } \\
\text { systemically important } \\
\text { Euroclear System (ES), and } \\
\text { further strengthen } \\
\text { cooperation in this area } \\
\text { between the NBB and the } \\
\text { CBFA. }\end{array}$ & $\begin{array}{l}\text { Recently conducted EU FSAP found that Euroclear Bank is subject to effective } \\
\text { regulation, supervision and oversight of the NBB. The new institutional } \\
\text { framework allows a focus on the operational and prudential aspects of the } \\
\text { organization to be integrated at the NBB. Important risk measures have been } \\
\text { taken to reduce systemic risk, but some risk management frameworks need } \\
\text { further improvement to fully observe the recently adopted international } \\
\text { standards, while cooperation with the Luxembourg authorities should be } \\
\text { improved. }\end{array}$ \\
\hline $\begin{array}{l}\text { Build on the progress made } \\
\text { so far to take fuller } \\
\text { advantage of the synergies } \\
\text { between the NBB and the } \\
\text { CBFA, and make the CBFA } \\
\text { work more efficiently and } \\
\text { effectively within the } \\
\text { existing legal structure. }\end{array}$ & $\begin{array}{l}\text { In order to improve the synergies between macro and microprudential } \\
\text { supervision, microprudential supervision was moved back to the NBB in } 2011 \text {, } \\
\text { with the new FSMA acting as a market and conduct regulator .The FSMA does, } \\
\text { however, retain some prudential responsibility for 'low risk' firms. }\end{array}$ \\
\hline $\begin{array}{l}\text { Further refine the existing } \\
\text { crisis management } \\
\text { arrangements to ensure } \\
\text { that there is an effective } \\
\text { and tested crisis } \\
\text { management mechanism in } \\
\text { place. }\end{array}$ & $\begin{array}{l}\text { Crisis management arrangements were tested in actual practice during the } \\
\text { financial crisis. The authorities demonstrated capacity to intervene decisively } \\
\text { and rapidly. Important modifications in legal framework of crisis management } \\
\text { have been implemented but the developments also highlighted scope for } \\
\text { further improvements, including with regard to (i) the legal framework and } \\
\text { crisis management tools; (ii) the development of resolution strategies that } \\
\text { could guide an eventual intervention; and (iii) cross-border collaboration and } \\
\text { coordination. Going forward, the ongoing strengthening of prudential } \\
\text { supervision and the integration of prudential supervision in the central bank is } \\
\text { expected to prove beneficial for contingency planning and crisis management, } \\
\text { and the establishment of an industry funded. The Resolution Fund will, in due } \\
\text { course, allow for a more equitable financing of resolution actions. }\end{array}$ \\
\hline $\begin{array}{l}\text { Introduce more flexibility in } \\
\text { setting the maximum } \\
\text { guaranteed rate in life } \\
\text { insurance and de-link the } \\
\text { guaranteed rates in } \\
\text { insurance and pensions to } \\
\text { prevent a further build-up } \\
\text { of vulnerabilities. }\end{array}$ & $\begin{array}{l}\text { The NBB's prudential decision to lower the maximum interest rate from } 3.75 \\
\text { percent to } 2 \text { percent was vetoed by the Ministry of Economy and Consumer } \\
\text { Affairs at end-2012. The key prudential risk following this decision is that } \\
\text { insurers continue to offer the same maximum guarantee rate for competitive } \\
\text { reasons (as evidenced in the past), despite significant uncertainties as to } \\
\text { whether they are able to generate investment returns of } 3.75 \text { percent, over the } \\
\text { next } 10 \text { to } 20 \text { years. The NBB is empowered to intervene on a case-by-case } \\
\text { basis if it opines an insurer offers a guarantee rate imprudently. }\end{array}$ \\
\hline
\end{tabular}




\begin{tabular}{|c|c|}
\hline $\begin{array}{l}\text { Begin strengthening } \\
\text { substantially the prudential } \\
\text { supervision of pension } \\
\text { funds. }\end{array}$ & $\begin{array}{l}\text { The FSMA is responsible for regulation and supervision of pension funds. The } \\
\text { legislation on pension funds has been substantially reformed at the occasion } \\
\text { of the implementation of the IORP Directive }{ }^{1} \text { into Belgian law. Staffing has } \\
\text { been increased and the supervisory program intensified. A recent EIOPA peer } \\
\text { assessment was favorable. }\end{array}$ \\
\hline \multicolumn{2}{|l|}{ Medium-term challenges } \\
\hline $\begin{array}{l}\text { Ensure that the capacity to } \\
\text { identify and address } \\
\text { financial system risks keeps } \\
\text { pace with market } \\
\text { developments, innovations, } \\
\text { and increasing complexity } \\
\text { of financial conglomerates. }\end{array}$ & $\begin{array}{l}\text { A new supervisory framework combines risk analysis and regulatory work. The } \\
\text { NBB established a risk dashboard of macro-financial indicators (which is } \\
\text { discussed at monthly Macro-financial Committee meetings), is developing a } \\
\text { framework for domestic systemically important financial institutions, has } \\
\text { enhanced market intelligence gathering, improved data reporting, and focused } \\
\text { research on improving stress testing and measurement of systemic risk. }\end{array}$ \\
\hline $\begin{array}{l}\text { Overhaul the supervision of } \\
\text { the pension industry. }\end{array}$ & $\begin{array}{l}\text { Pension supervision is within the remit of the FSMA since } 2011 \text {. The pension } \\
\text { supervision system was not evaluated as part of this FSAP. }\end{array}$ \\
\hline $\begin{array}{l}\text { Revisit a number of features } \\
\text { in the supervisory } \\
\text { institutional arrangements } \\
\text { in light of the experience } \\
\text { gained, with the view to } \\
\text { further enhancing synergies } \\
\text { with the NBB and } \\
\text { strengthening the } \\
\text { effectiveness of the } \\
\text { management boards of the } \\
\text { CBFA and the Financial } \\
\text { Stability Committee. }\end{array}$ & $\begin{array}{l}\text { The Financial Stability Committee no longer exists as a result of the } \\
\text { introduction of the new institutional model in } 2011 \text { (see above). Composition } \\
\text { of the board of the NBB did not change with the introduction of the new } \\
\text { institutional structure. }\end{array}$ \\
\hline $\begin{array}{l}\text { Streamline and harmonize } \\
\text { laws and regulations } \\
\text { applicable to the mandate } \\
\text { of the CBFA }\end{array}$ & $\begin{array}{l}\text { Harmonization of standards across the sectors, for example in the rules that } \\
\text { apply to products packaged as asset management, banking or insurance } \\
\text { products but which have similar features, is largely dependent on the EU } \\
\text { framework. The authorities have worked within that framework to ensure like } \\
\text { activities are treated in the same way to the extent possible but challenges } \\
\text { remain, particularly in the case of guaranteed investment products sold by } \\
\text { insurers. }\end{array}$ \\
\hline $\begin{array}{l}\text { Meet the challenges of the } \\
\text { implementation of the } \\
\text { Financial Services Action } \\
\text { Plan and reap the benefits } \\
\text { of European integration. }\end{array}$ & $\begin{array}{l}\text { Belgium has fully participated in integration. All aspects of the Financial } \\
\text { Services Action Plan have been transposed. }\end{array}$ \\
\hline
\end{tabular}

\footnotetext{
${ }^{1}$ Directive 2003/41/EC of the European Parliament and of the Council of 3 June 2003 on the activities and supervision of institutions for occupational retirement provision.
} 


\section{Appendix III. Crisis Intervention and Restructuring Measures}

$\boldsymbol{K} \boldsymbol{B C}$ - benefited from state support in the initial phase of the crisis. KBC remains a privately owned, Belgian financial conglomerate:

- In $2008 \mathrm{KBC}$ received capital injections of $€ 3.5$ billion by the federal government and $€ 3.5$ billion by the Flemish regional government in 2009 as well as asset guarantees of $€ 15.1$ billion (2009). At the end of 2012, the federal government and KBC have reached an agreement, which limit the asset guarantee to $€ 9.4$ billion.

- The divestment plan proposed in 2009 entailed a withdrawal from noncore markets in Central and Eastern Europe and a sale of noncore activities in Belgium (Fidea and Centea). The structured product portfolio was also put in run-off. In 2010-2013, important asset disposals took place including the sale of the private banking subsidiary $\mathrm{KBL}$, of the Polish subsidiaries (Kredyt Bank, Zagiel, and Warta), and of the Russian (Absolut Bank) and Slovenian (NBL) operations.

- Federal state capital injections were repaid in full with a first tranche of capital support of $€ 0.5$ billion at the beginning of in 2012 and a second one of $€ 3.0$ billion (besides a penalty of $€ 0.45$ billion) at end of 2012. The group has also announced a first tranche of repayment of the Flemish government support in 2013. The group has successfully raised private capital in the form of new equity ( $€ 1.2$ billion) and contingent capital instruments ( $€ 0.75$ billion) in January 2013.

Dexia - was intervened successively later in the crisis. The restructuring resulted in a runoff group (headed by Dexia SA) and the sale of operational entities including the Belgian bank subsidiary (Belfius) to the Belgian State for $€ 4$ billion):

- In 2008, Dexia Group had been recapitalized by the states of Belgium and France in total amount of $€ 3$ billion of which Belgian state and the three regions subscribed $€ 2$ billion. The states of Belgium, France, and Luxembourg also issued a funding guarantee of $€ 150$ billion, which has been used up to $€ 95$ billion, and Belgium and France guaranteed an asset portfolio of $\$ 12.5$ billion in the U.S. subsidiary FSA (sold in 2011 without invoking the guarantee).

- In 2011 further intervention was required when the group lost again market access. The restructuring plan entailed: i) an orderly run off of the group's long-term assets supported by 
a funding guarantees provided by Belgium, France and Luxembourg (of up to $€ 90$ billion); ii) the disposal of the international operations (Turkish, Canadian, and Luxembourg operations were all sold in 2012); and iii) the sale of Dexia Bank Belgium to the Belgian state for $€ 4$ billion and rebranded in 2012 as Belfius.

- In 2012, additional state capital injections of $€ 5.5$ billion were made into Dexia SA by Belgium ( $€ 2.9$ billion) and France ( $€ 2.6$ billion), and the 2011 guarantee receives a final approval from the European Commission in amount of $€ 85$ billion under a modified burden sharing key, more favorable for the Belgian state.

- Dexia's French lending operations (Dexia Municipal Agency) will be merged into a new entity with participations from the French state, Caisse des Depôts et Consignations (CDC) and the postal bank.

Fortis - the former Belgian group was nationalized by Dutch and Belgian authorities, while subsequently the Belgian subsidiary was sold to BNP Paribas:

- In 2008, the Belgian and Dutch states acquired the majority of shares of Fortis for $€ 9.4$ billion.

- In 2009, a 75 percent stake of the Belgian subsidiary was sold to BNP Paribas and the Belgian state also provided a second-loss guarantee on the structured credit portfolio retained by Fortis ( $€ 2$ billion), which has come to an end at the end of 2012 after an agreement between BNP Fortis and the Belgian state. As part of the sale to BNP $€ 11.4$ billion assets were transferred to an asset management SPV (Royal Park Investments) co-owned by the Belgian state, BNP Paribas, and Fortis/Ageas and additional funding guarantees of $€ 4.9$ billion were provided to RPI. The group's insurance arm was transferred a 10 percent stake to BNP Paribas, while the rest remained under the Belgian subsidiary Ageas.

- In 2011, the restructuring of the Turkish operations was finalized.

Ethias - a mutual insurance company with a balance sheet of 7 percent of GDP and a 5 percent stake in Dexia received state support and was required to restructure:

- In 2008, Ethias received capital injections of $€ 1.5$ billion by the Belgian, Walloon and Flemish governments conditioned by the wind down of its retail life insurance business. 
- In 2011, Ethias incurred heavy losses from its stake participation in Dexia and received further public sector support of $€ 180$ million in a bond issue in January 2012. At the end of 2012, Ethias has sold all remaining shares in Dexia. 


\section{Appendix IV. Risk Assessment Matrix ${ }^{1}$}

\begin{tabular}{|c|c|c|}
\hline \multirow{2}{*}{$\begin{array}{l}\text { Nature/Source of Main } \\
\text { Threats }\end{array}$} & \multicolumn{2}{|c|}{ Overall Level of Concern } \\
\hline & $\begin{array}{l}\text { Relative Likelihood } \\
\text { (high, medium, or low) }\end{array}$ & $\begin{array}{c}\text { Potential Impact on Financial } \\
\text { Stability if Threat is Realized } \\
\text { (high, medium, or low) }\end{array}$ \\
\hline $\begin{array}{l}\text { 1. Protracted period of } \\
\text { slow European growth } \\
\text { and persistent low } \\
\text { interest rates }\end{array}$ & $\begin{array}{l}\text { Medium } \\
\text { The WEO forecast remains flat; } \\
\text { with no sharp or deep decline but } \\
\text { consensus forecasts are less optimistic } \\
\text { There is a risk that recovery } \\
\text { does not take hold or that euro area or } \\
\text { global slowdown becomes worse than } \\
\text { anticipated } \\
\quad \text { Drag of confidence in euro } \\
\text { area sovereigns on growth could be } \\
\text { amplified } \\
\text { The likelihood of this risk } \\
\text { materializing is heightened by } \\
\text { continuing policy uncertainty in euro } \\
\text { area, and an increasing impact of } \\
\text { austerity measures on the region }\end{array}$ & $\begin{array}{l}\text { High } \\
\text { Further erosion of the } \\
\text { economic position of insurers and } \\
\text { banks reduces their risk bearing } \\
\text { capacity } \\
\text { Bank and insurer profitability } \\
\text { and ability to rebuild capital levels } \\
\text { would be crippled; ability to complete } \\
\text { restructurings compromised } \\
\text { - Asset price decline would be } \\
\text { a further hit to balance sheets }\end{array}$ \\
\hline $\begin{array}{l}\text { 2. Political uncertainty } \\
\text { and fiscal strain cause } \\
\text { sharp widening of } \\
\text { sovereign spreads }\end{array}$ & $\begin{array}{l}\text { Medium } \\
\text { Debt levels are high and have } \\
\text { risen significantly owing mainly to crisis } \\
\text { measures } \\
\text { Sovereign-financial sector link } \\
\text { further intensified } \\
\text { Political stability is fragile as } \\
\text { uncertainty continues in the run up to } \\
\text { elections, could result in a relaxation of } \\
\text { fiscal discipline } \\
\text { - Yields have remained low into } \\
2013 \text { and some pre-financing has taken } \\
\text { place; however, there are large } \\
\text { refinancing needs in } 2013 \text { and } 2014\end{array}$ & $\begin{array}{l}\text { Medium } \\
\quad \text { Large direct exposure to } \\
\text { Belgian sovereign leaves banks and } \\
\text { insurers vulnerable to sharp spread } \\
\text { widening, which would pass through } \\
\text { to solvency and liquidity positions } \\
\text { Collateral haircuts could } \\
\text { place a further strain on liquidity } \\
\text { management and restructuring in an } \\
\text { environment where tolerance for } \\
\text { liquidity risk is already limited } \\
\quad \text { A sovereign downgrade } \\
\text { would be likely followed by a } \\
\text { downgrade to banks and insurers, } \\
\text { driving up funding costs. }\end{array}$ \\
\hline $\begin{array}{l}\text { 3. Spillover from strong } \\
\text { intensification of euro } \\
\text { area crisis }\end{array}$ & $\begin{array}{l}\text { Medium } \\
\text { Stalled or incomplete delivery } \\
\text { or incomplete commitments at the }\end{array}$ & $\begin{array}{l}\text { High } \\
\text { Given Belgium's deep } \\
\text { integration in the euro area, }\end{array}$ \\
\hline
\end{tabular}

\footnotetext{
${ }^{1}$ The Risk Assessment Matrix (RAM) shows events that could materially alter the baseline path discussed in this report (which is the scenario most likely to materialize in the view of IMF staff). The relative likelihood of risks listed is the staff's subjective assessment of the risks surrounding this baseline. The RAM reflects staff's views on the source of risks and overall level of concerns as of the time of discussions with the authorities.
} 


\begin{tabular}{|c|c|c|}
\hline \multirow{3}{*}{$\begin{array}{l}\text { Nature/Source of Main } \\
\text { Threats }\end{array}$} & \multicolumn{2}{|c|}{ Overall Level of Concern } \\
\hline & $\begin{array}{l}\text { Relative Likelihood } \\
\text { (high, medium, or low) }\end{array}$ & $\begin{array}{c}\text { Potential Impact on Financial } \\
\text { Stability if Threat is Realized } \\
\text { (high, medium, or low) }\end{array}$ \\
\hline & 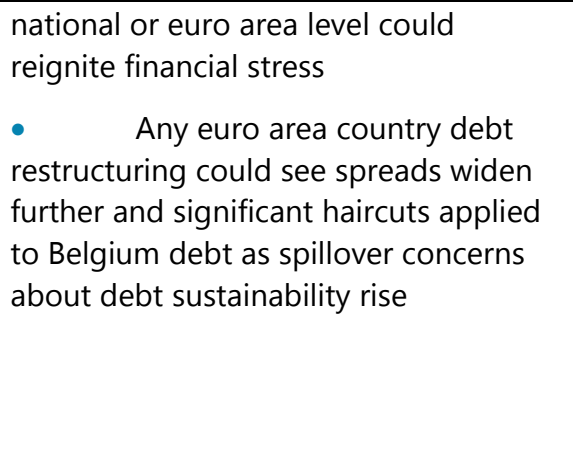 & $\begin{array}{l}\text { contagion from the fallout could see } \\
\text { financial market stress exceeding } \\
\text { levels following the collapse of } \\
\text { Lehman and significant deposit runs. } \\
\text { Banks' direct exposure to } \\
\text { peripheral countries is limited and } \\
\text { falling, with the exception of Italy. } \\
\text { There is no direct exposure via } \\
\text { subsidiaries, except for Ireland. } \\
\text { Insurers' exposure is limited. }\end{array}$ \\
\hline $\begin{array}{l}\text { 4. Housing price } \\
\text { correction }\end{array}$ & $\begin{array}{l}\text { Medium } \\
\text { House prices have more than } \\
\text { doubled in ten years and increased } \\
\text { steadily through the financial crisis, } \\
\text { outpacing increases in other advanced } \\
\text { countries } \\
\text { The share of variable interest } \\
\text { rate in total household debt has risen } \\
\text { for low income households, increasing } \\
\text { vulnerability to unemployment and } \\
\text { disposable income shock. } \\
\quad \text { While unemployment remains } \\
\text { - } \\
\text { moderate, there is a downside risk if } \\
\text { weak outlook in Europe persists } \\
\text { Most properties are owner } \\
\text { occupied, Belgian households have high } \\
\text { net worth } \\
\text { - LTV ratios remain moderate on } \\
\text { average, however there are pockets of } \\
\text { vulnerability in new vintages of } \\
\text { mortgage loans }\end{array}$ & $\begin{array}{l}\text { Medium } \\
\text { Sharp housing downturn } \\
\text { would compound bank capital } \\
\text { pressures in the medium term. } \\
\text { Structural features suggest } \\
\text { that a gradual correction is likely, } \\
\text { leaving banks time to adjust } \\
\text { Staff estimates suggest only } \\
\text { a moderate overvaluation of housing } \\
\text { stock }\end{array}$ \\
\hline
\end{tabular}




\section{Appendix V. Overview of Stress Tests for Banks}

\begin{tabular}{|c|c|c|c|c|c|}
\hline \multirow[b]{2}{*}{ Firm } & \multicolumn{3}{|c|}{ Solo Basis } & \multicolumn{2}{|c|}{ Consolidated Basis } \\
\hline & Total Assets & $\begin{array}{l}\text { percent of } \\
\text { peer group }\end{array}$ & $\begin{array}{l}\text { percent of } \\
\text { banking } \\
\text { sector }\end{array}$ & Total Assets & $\begin{array}{l}\text { percent of } \\
\text { banking } \\
\text { sector }\end{array}$ \\
\hline \multicolumn{6}{|l|}{ Group 1 - Large banks } \\
\hline BNPP Fortis & $283,539.3$ & 32.85 & 26.97 & $349,767.1$ & 30.04 \\
\hline KBC Bank & $168,618.1$ & 19.54 & 16.04 & $243,748.5$ & 20.94 \\
\hline Belfius (ex Dexia Bank Belgium) & $187,564.0$ & 21.73 & 17.84 & $201,877.9$ & 17.34 \\
\hline ING Belgium & $151,771.5$ & 17.59 & 14.44 & $177,836.1$ & 15.27 \\
\hline AXA Bank Europe & $38,759.3$ & 4.49 & 3.69 & $41,450.5$ & 3.56 \\
\hline Argenta & $32,790.7$ & 3.80 & 3.12 & $34,951.3$ & 3.00 \\
\hline Subtotal & $863,042.8$ & 100.00 & 82.09 & $1,049,631.4$ & 90.15 \\
\hline \multicolumn{5}{|l|}{ Group 2 - Small retail banks } & \\
\hline Subtotal & $88,067.1$ & - & 8.38 & $59,837.8$ & 3.22 \\
\hline \multicolumn{6}{|l|}{$\begin{array}{l}\text { Group } 3 \text { - Small corporate } \\
\text { banks ( } 7 \text { banks) }\end{array}$} \\
\hline Subtotal & $18,160.0$ & - & 1.73 & $1,864.5$ & 0.00 \\
\hline \multicolumn{6}{|l|}{$\begin{array}{l}\text { Group } 4 \text { - Small private banks } \\
\text { (10 banks) }\end{array}$} \\
\hline Subtotal & $8,284.5$ & - & 0.79 & $7,775.3$ & 0.67 \\
\hline Total sample & $977,554.5$ & - & 92.98 & $1,094,894.7$ & 94.04 \\
\hline System coverage (percent) & 80.95 & - & - & 82.91 & - \\
\hline \multicolumn{6}{|l|}{ Memo items } \\
\hline Foreign branches & $156,238.7$ & - & - & $156,238.7$ & - \\
\hline Other banks & $73,820.3$ & - & - & $69,386.1$ & - \\
\hline$\underline{\text { Total system }}$ & $1,207,613.5$ & - & - & $1,320,519.4$ & - \\
\hline \multicolumn{6}{|c|}{$\begin{array}{l}\text { Notes: } \\
\text { 1. Banks which only have a solo reporting and which are not consolidated within another Belgian bank are excluded } \\
\text { from the consolidated sample. }\end{array}$} \\
\hline \multicolumn{6}{|c|}{$\begin{array}{l}\text { 2. In order to avoid double counting in the consolidated sample, total sample figures are calculated by excluding the } \\
\text { four banks which, while having a consolidated reporting on their own, are also consolidated within another bank: } \\
\text { Europabank and Keytrade (both consolidated within Landbouwkrediet), Record Bank (consolidated within ING Belgium) } \\
\text { and Antwerpse Diamantbank (consolidated within KBC Bank). }\end{array}$} \\
\hline $\begin{array}{l}\text { 3. The "other banks" category cont } \\
\text { stress-test exercise). }\end{array}$ & wo main insti & ons: Eurocl & and Bank & (not part o & SAP \\
\hline
\end{tabular}


Table 5.2: Stress Test Matrix (STeM) for the Banking Sector: Solvency and Liquidity Risks

\begin{tabular}{|c|c|c|c|}
\hline \multirow{2}{*}{\multicolumn{2}{|c|}{ Domain }} & \multicolumn{2}{|c|}{ Assumptions } \\
\hline & & Bottom-Up by Banks & Top-down by NBB and FSAP Team \\
\hline \multicolumn{4}{|c|}{ BANKING SECtOR: SOlvenCy RISK } \\
\hline \multirow[t]{3}{*}{$\begin{array}{l}\text { 1.Institutional } \\
\text { Perimeter }\end{array}$} & Institutions included & $\begin{array}{l}\quad 6 \text { largest banks (KBC, Belfius, BNP } \\
\text { Paribas Fortis, ING Belgium, AXA Bank Europe, } \\
\text { and Argenta). }\end{array}$ & $\begin{array}{l}\text { entire banking system, excluding Dexia } \\
\text { SA (in a runoff under the restructuring plan), } \\
\text { foreign branches, Euroclear and Bank of NY } \\
\text { Mellon (which is a custodian bank). } \\
\text { consolidated into three groups based on } \\
\text { proximity of business models: small retail banks, } \\
\text { small corporate banks and small private banks. }\end{array}$ \\
\hline & Market share & $\begin{array}{l}\text { - } 82 \text { percent of total banking sector } \\
\text { assets (excluding foreign branches) on a solo } \\
\text { basis and } 90 \text { percent on a consolidated basis. }\end{array}$ & $\begin{array}{l}\text { - } 93 \text { percent of total banking sector } \\
\text { assets excluding foreign branches. }\end{array}$ \\
\hline & $\begin{array}{l}\text { Data and baseline } \\
\text { date }\end{array}$ & $\begin{array}{l}\text { Source: institutions' own granular data. } \\
\text { Date: end-June } 2012 \text { (projected to } \\
\text { end-2012). } \\
\text { Scope: consolidated banking group. } \\
\text { Coverage of sovereign risk: all direct } \\
\text { and indirect net exposures in both trading and } \\
\text { investment book. }\end{array}$ & $\begin{array}{l}\text { Source: supervisory data. } \\
\text { Date: end-June } 2012 \text { (projected to } \\
\text { end-2012). } \\
\text { Scope: legal entity (solo basis). } \\
\text { Coverage of sovereign risk: all direct } \\
\text { and indirect net exposures in both trading and } \\
\text { investment book. }\end{array}$ \\
\hline \multirow[t]{2}{*}{$\begin{array}{l}\text { 2. Channels of } \\
\text { Risk Propagation }\end{array}$} & Methodology & $\begin{array}{l}\text { Banks' internal models. } \\
\text { BU guidance (IMF, 2011a) } \\
\text { Valuation haircut model for sovereign } \\
\text { risk (Jobst and others, forthcoming; IMF, 2012). }{ }^{1}\end{array}$ & $\begin{array}{l}\text { Balance sheet-based model (IMF, } \\
2011 b \text { and 2012). }{ }^{2} \\
\text { Valuation haircut model for sovereign } \\
\text { risk (Jobst and others, forthcoming; IMF, 2012). }\end{array}$ \\
\hline & $\begin{array}{l}\text { Satellite Models for } \\
\text { Macro-Financial }\end{array}$ & $\begin{array}{l}\text { Macro-financial linkages are estimated } \\
\text { based on firm's internal models to forecast the }\end{array}$ & $\begin{array}{l}\text { Macro-financial linkages are estimated } \\
\text { based on SLS panel data regression (using }\end{array}$ \\
\hline
\end{tabular}

\footnotetext{
${ }^{1}$ IMF, 2011a, "United Kingdom: Stress Testing the Banking Sector Technical Note," Country Report No. 11/222, 1 July (Washington, D.C.: International Monetary Fund), available at http://www.imf.org/external/pubs/ft/scr/2011/cr11227.pdf; IMF, 2012, "Spain: Financial System Stability Assessment," IMF Country Report 12/137, 30 May (Washington, D.C.: International Monetary Fund), available at http://www.imf.org/external/pubs/ft/scr/2012/cr12137.pdf; and Jobst, Andreas A., Hardy, Daniel, and Christian Schmieder, forthcoming, "Sovereign Haircuts," IMF Working Paper (Washington, D.C.: International Monetary Fund).

${ }^{2}$ IMF, 2011b, "Germany: Technical Note on Stress Testing," Country Report No. 11/371, 23 December (Washington, D.C.: International Monetary Fund), available at http://www.imf.org/external/pubs/ft/scr/2011/cr11371.pdf.
} 


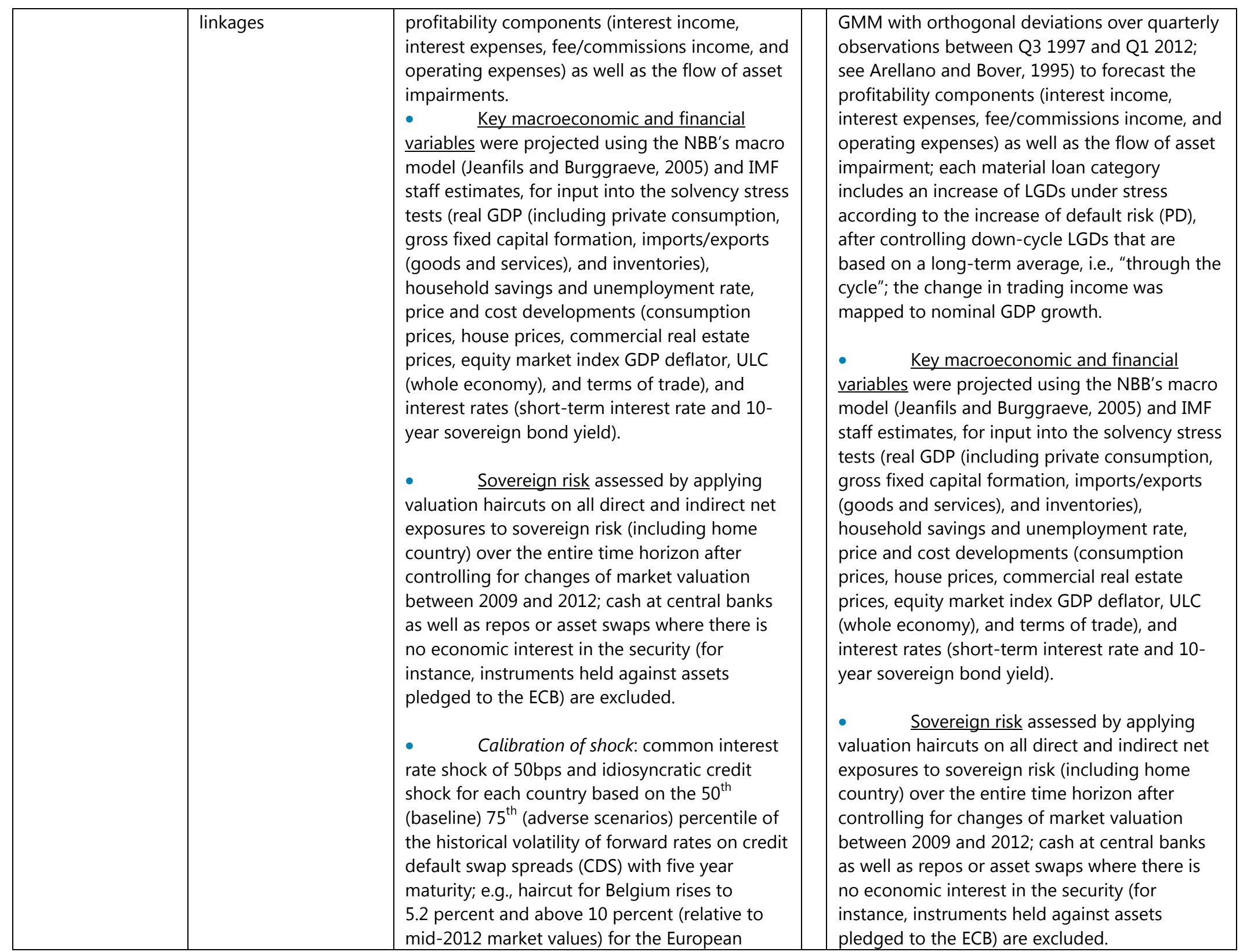




\begin{tabular}{|c|c|c|c|}
\hline & & $\begin{array}{l}\text { periphery in adverse scenario). } \\
\quad \text { Exposure: trading book as well as } \\
\text { available-for-sale (AfS) and hold-to-maturity } \\
\text { (HtM) assets; Belgium is not excluded. } \\
\text { Cross-border effects are considered in } \\
\text { all macro scenarios: IMF staff provided } \\
\text { estimates for real GDP growth, inflation, and } \\
\text { short-term interest rates consistent with the } \\
\text { macroeconomic forecast for Belgium under } \\
\text { both baseline and adverse scenarios for all } \\
\text { relevant countries (Czech Republic, France, } \\
\text { Germany, Hungary, Ireland, the Netherlands, } \\
\text { Switzerland, and Turkey) affecting bank } \\
\text { performance abroad. }\end{array}$ & 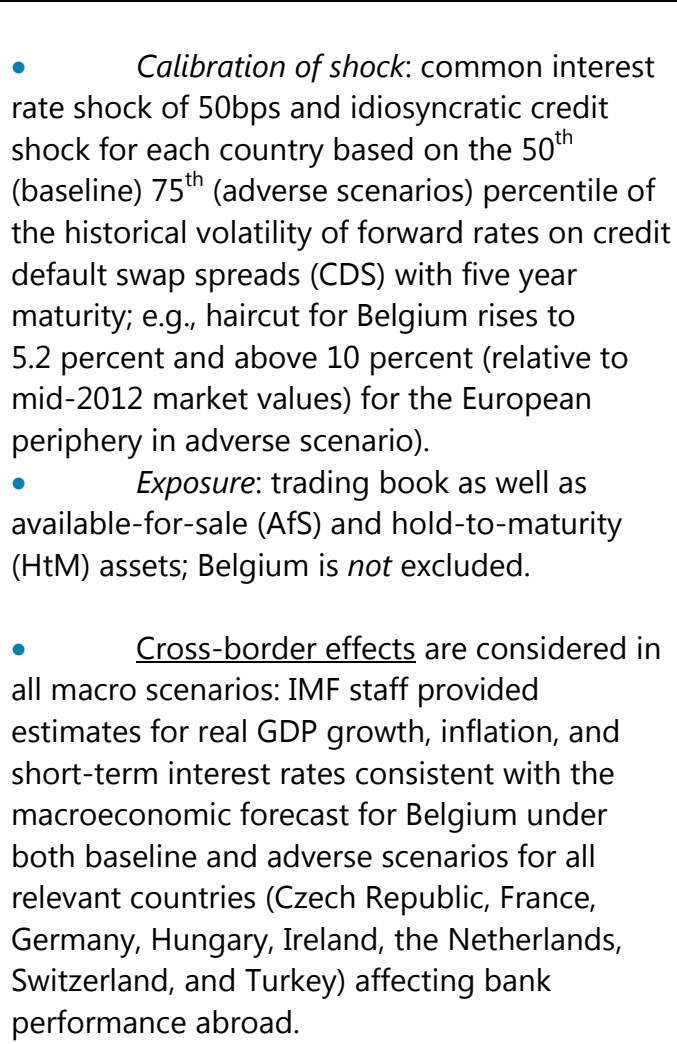 \\
\hline & Stress test horizon & 2013-2017 (five years). & 2013-2017 (five years). \\
\hline 3. Tail shocks & Scenario analysis & $\begin{array}{l}\text { Baseline: October } 2012 \text { WEO, real GDP } \\
\text { growth rate for } 2013 \text { is } 0.3 \text { percent and for } 2014 \\
\text { is } 1.0 \text { percent. } \\
\text { standard deviations of real GDP growth (based } \\
\text { on the volatility of the two-year growth rate } \\
\text { between } 1982 \text { and 2011) from the baseline } \\
\text { growth trend. This scenario results in a } \\
\text { cumulative negative deviation of about } 4.7 \\
\text { percentage points in real GDP over a five-year } \\
\text { horizon (with a sharp decline of output and }\end{array}$ & $\begin{array}{l}\text { Baseline: October } 2012 \text { WEO, real GDP } \\
\text { growth rate for } 2013 \text { is } 0.3 \text { percent and for } 2014 \\
\text { is } 1.0 \text { percent. } \\
\text { standard deviations of real GDP growth (based } \\
\text { on the volatility of the two-year growth rate } \\
\text { between } 1982 \text { and 2011) from the baseline } \\
\text { growth trend. This scenario results in a } \\
\text { cumulative negative deviation of about } 4.7 \\
\text { percentage points in real GDP over a five-year } \\
\text { horizon (with a sharp decline of output and }\end{array}$ \\
\hline
\end{tabular}




\begin{tabular}{|c|c|c|c|}
\hline & & $\begin{array}{l}\text { rising inflation over the first two years but } \\
\text { positive adjustment dynamics during the } \\
\text { subsequent three years). } \\
\text { - Adverse (Slow Growth): cumulative } \\
\text { negative deviation of about } 4.5 \text { percentage } \\
\text { points in real GDP (at a constant rate of } \\
\text { deviation from the annual baseline growth rate } \\
\text { of } 0.9 \text { percent over a five-year horizon), as a } \\
\text { result of continued shocks to demand amid } \\
\text { rising inflation expectations. }\end{array}$ & $\begin{array}{l}\text { rising inflation over the first two years but } \\
\text { positive adjustment dynamics during the } \\
\text { subsequent three years). } \\
\text { - Adverse (Slow Growth): cumulative } \\
\text { negative deviation of about } 4.5 \text { percentage } \\
\text { points in real GDP (at a constant rate of } \\
\text { deviation from the annual baseline growth rate } \\
\text { of } 0.9 \text { percent over a five-year horizon), as a } \\
\text { result of continued shocks to demand amid } \\
\text { rising inflation expectations. }\end{array}$ \\
\hline & Sensitivity analysis & $\begin{array}{l}\text { FX shock: included in market RWAs } \\
\text { under Basel } 2.5 \text { as of end-December } 2011 .\end{array}$ & $\begin{array}{l}\text { FX shock: firms are asked to report the } \\
\text { aggregate impact of the following FX shock of } \\
\text { the following currencies on FX net open } \\
\text { positions and FX assets: U.S. dollar, Pound } \\
\text { sterling and Japanese yen. The shock for each } \\
\text { currency calibrated to four times (twice) the } \\
\text { standard deviation of the respective FX volatility } \\
\text { during } 2011 \text { for the "double dip" ("slow } \\
\text { growth") scenario and impact the trading book } \\
\text { in } 2013 \text { (100 percent) and } 2014 \text { ( } 50 \text { percent) } \\
\text { only. }\end{array}$ \\
\hline \multirow[t]{2}{*}{ 4.Risks and Buffers } & $\begin{array}{l}\text { Risks/factors assessed } \\
\text { (How each element is } \\
\text { derived, assumptions.) }\end{array}$ & $\begin{array}{l}\text { Credit risk (households and } \\
\text { corporates, domestic and foreign exposures). } \\
\text { Sovereign risk for all government } \\
\text { bonds and indirect sovereign exposure. } \\
\text { Counterparty risk in the banking book. } \\
\text { Funding risk (additional add-on to } \\
\text { interest expenses, contingent on Tier } 1 \\
\text { capitalization). } \\
\text { Market risk, including FX risks. } \\
\text { Tax rate: } 30 \text { percent. }\end{array}$ & $\begin{array}{l}\text { Credit risk (households and corporates, } \\
\text { domestic and foreign exposures). } \\
\text { Sovereign risk for all government } \\
\text { bonds and indirect sovereign exposure. } \\
\text { Counterparty risk in the banking book. } \\
\text { Funding risk (additional add-on to } \\
\text { interest expenses, contingent on Tier } 1 \\
\text { capitalization). } \\
\text { Market risk, including FX risks. } \\
\text { Tax rate: } 30 \text { percent. }\end{array}$ \\
\hline & $\begin{array}{l}\text { Behavioral } \\
\text { adjustments }\end{array}$ & $\begin{array}{l}\text { Static balance sheet, but constant } \\
\text { funding structure and credit growth (i.e., } \\
\text { lending increases in line with nominal GDP (if } \\
\text { positive)), subject to a "deleveraging rule"; no } \\
\text { asset disposals/divestments after cut-off date; } \\
\text { defaulted loans are not replenished. } \\
\text { Dividend payout depends on }\end{array}$ & $\begin{array}{l}\text { Static balance sheet, but constant } \\
\text { funding structure and credit growth (i.e., } \\
\text { lending increases in line with nominal GDP (if } \\
\text { positive)), subject to a "deleveraging rule"; no } \\
\text { asset disposals/divestments after cut-off date; } \\
\text { defaulted loans are not replenished. } \\
\text { Dividend payout depends on }\end{array}$ \\
\hline
\end{tabular}




\begin{tabular}{|c|c|c|c|}
\hline & & $\begin{array}{l}\text { capitalization under stress: dividend pay-out } \\
\text { only if firm reports profits over the past year; if } \\
\text { total capital ratio is above } 8.0 \text { percent (after the } \\
\text { envisaged dividend payout and, at the same } \\
\text { time, exhibits sufficient Tier } 1 \text { and core Tier1 } \\
\text { capitalization) but below } 10.5 \text { percent (which } \\
\text { reflects the magnitude of the CAR and "capital } \\
\text { conservation buffer" under Basel III), the firm is } \\
\text { considered capital-constrained and restricts } \\
\text { dividend; however, firms that are not capital } \\
\text { constrained will have to pay out at least } 40 \\
\text { percent of earnings after tax each year. } \\
\text { Credit growth in line with nominal } \\
\text { GDP for banks with a Tier } 1 \text { capital buffer of } 2.5 \\
\text { percentage points above the regulatory } \\
\text { minimum (for Tier 1); credit growth decreases } \\
\text { by } 2 \text { percentage points for each decrease in Tier } \\
1 \text { capital by } 1 \text { percentage point once the buffer } \\
\text { is less than } 2.5 \text { percentage points. Hence, } \\
\text { growth becomes negative when capitalization is } \\
\text { at minimum capital ratio. } \\
\text { - }\end{array}$ & $\begin{array}{l}\text { capitalization under stress: dividend pay-out } \\
\text { only if firm reports profits over the past year; if } \\
\text { total capital ratio is above } 8.0 \text { percent (after the } \\
\text { envisaged dividend payout and, at the same } \\
\text { time, exhibits sufficient Tier } 1 \text { and core Tier1 } \\
\text { capitalization) but below } 10.5 \text { percent (which } \\
\text { reflects the magnitude of the CAR and "capital } \\
\text { conservation buffer" under Basel III), the firm is } \\
\text { considered capital-constrained and restricts } \\
\text { dividend; however, firms that are not capital } \\
\text { constrained will have to pay out at least } 40 \\
\text { percent of earnings after tax each year. } \\
\text { Credit growth in line with nominal GDP } \\
\text { for banks with a Tier } 1 \text { capital buffer of } 2.5 \\
\text { percentage points above the regulatory } \\
\text { minimum (for Tier } 1 \text { ); credit growth decreases } \\
\text { by } 2 \text { percentage points for each decrease in Tier } \\
1 \text { capital by } 1 \text { percentage point once the buffer } \\
\text { is less than } 2.5 \text { percentage points. Hence, } \\
\text { growth becomes negative when capitalization is } \\
\text { at minimum capital ratio. }\end{array}$ \\
\hline \multirow[t]{2}{*}{$\begin{array}{l}\text { 5. Regulatory and } \\
\text { Market-Based } \\
\text { Standards and } \\
\text { Parameters }\end{array}$} & $\begin{array}{l}\text { Calibration of risk } \\
\text { parameters }\end{array}$ & $\begin{array}{l}\text { Banks' models for point in time PDs } \\
\text { and down-cycle LGDs. } \\
\text { RWAs were estimated using through- } \\
\text { the-cycle PDs, plus adjustments for loan } \\
\text { portfolio concentration and changes in default } \\
\text { risk. }\end{array}$ & $\begin{array}{l}\text { PDs and LGDs: PD estimated as change } \\
\text { in the stock of nonperforming loans (via satellite } \\
\text { model) while provisioning levels at the start of } \\
\text { the forecast horizon is maintained; thus, LGD is } \\
\text { assumed to be } 100 \text { percent. } \\
\text { RWAs are estimated in accordance } \\
\text { with AIRB under Basel III, plus adjustments for } \\
\text { loan portfolio concentration and changes in } \\
\text { default risk. }\end{array}$ \\
\hline & $\begin{array}{l}\text { Regulatory/Accountin } \\
\mathrm{g} \text { and Market-Based } \\
\text { Standards }\end{array}$ & $\begin{array}{l}\text { Full Basel III transition schedule. } \\
\text { Capital definition according to the } \\
\text { Basel III framework. During the forecast horizon } \\
\text { it has to comply with the envisaged phase-in of } \\
\text { capital deductions and the phase-out of } \\
\text { noneligible forms of capital, without } \\
\text { consideration of grandfathering. }\end{array}$ & $\begin{array}{l}\text { Full Basel III transition schedule. } \\
\text { Capital definition according to the } \\
\text { Basel III framework. During the forecast horizon } \\
\text { it has to comply with the envisaged phase-in of } \\
\text { capital deductions and the phase-out of } \\
\text { noneligible forms of capital, without } \\
\text { consideration of grandfathering. }\end{array}$ \\
\hline
\end{tabular}




\begin{tabular}{|c|c|c|c|}
\hline & & $\begin{array}{l}\text { Phase-in of total regulatory } \\
\text { adjustments to common CET1 capital: } 20 \\
\text { percent (per annum) of CET1 capital (such as } \\
\text { goodwill, deferred tax assets and minority } \\
\text { interests that exceed the permissible limit) } \\
\text { deducted between } 2014 \text { and 2017; firms must } \\
\text { document deductions if amount is less than } \\
\text { 29.0/20.4 percent [4 largest banks/other } \\
\text { banks] } 80 / 100=23.2 / 16.3 \text { percent ( } 29.0 / 20.4 \\
\text { percent is the average value for large banks } \\
\text { (Group 1)/small banks (Group 2) according to } \\
\text { the results from results from the Basel III } \\
\text { monitoring exercise as of } 31 \text { December } \\
\text { 2011QIS-7). } \\
\quad \text { Phase-out of non-CET1 and Tier } 2 \\
\text { capital elements: the higher of either } 10 \text { percent } \\
\text { (per annum) of the amount of capital to be } \\
\text { phased-out based on the QIS-6 results for } \\
\text { Group } 1 \text { (large banks) at } 26.8 \text { percent or the } \\
\text { amount of capital maturing each year subject to } \\
\text { phase-out between } 2013 \text { and } 2017 \text {. } \\
\quad \text { Risk-weighted assets (RWAs): } \\
\quad \text { RWAs for market and operational risk } \\
\text { remain constant throughout the forecast } \\
\text { period; } \\
\quad \text { RWAs for credit risk are subject to the } \\
\text { Basel I floor and sensitive to the regulatory } \\
\text { impact due to Basel III based on firm's own } \\
\text { data; there is no regulatory impact on RWAs for } \\
\text { market risk as Belgium has adopted Basel } 2.5 \\
\text { on } 31 \text { December } 2011 \text { in inddition, credit RWAs } \\
\text { are sensitive both changes in PDs and portfolio } \\
\text { correlations: (a) nonlinear effect of changes in } \\
\text { PDs and (b) concentration risk impact on RWAs. } \\
\quad \text { RWA impact of defaulted loans: The } \\
\text { risk-weights for credit risk are subsequently } \\
\text { reduced by the RWAs of defaulted exposures, } \\
\text { which are approximated by taking } 2.5 \text { times the }\end{array}$ & $\begin{array}{l}\text { Phase-in of total regulatory } \\
\text { adjustments to common CET1 capital: } 20 \text { percent } \\
\text { (per annum) of CET1 capital (such as goodwill, } \\
\text { deferred tax assets and minority interests that } \\
\text { exceed the permissible limit) deducted between } \\
2014 \text { and 2017; } 29.0 / 20.4 \text { percent [4 largest } \\
\text { banks/other banks] } 80 / 100=23.2 / 16.3 \text { percent } \\
\text { (29.0/20.4 percent is the average value for large } \\
\text { banks (Group 1)/small banks (Group 2) } \\
\text { according to the results from results from the } \\
\text { Basel III monitoring exercise as of } 31 \text { December } \\
\text { 2011QIS-7). } \\
\quad \text { Phase-out of non-CET1 and Tier } 2 \\
\text { capital elements: the higher of either } 10 \text { percent } \\
\text { (per annum) of the amount of capital to be } \\
\text { phased-out based on the QIS-6 results for } \\
\text { Group } 1 \text { (large banks) at } 26.8 \text { percent. } \\
\quad \text { Risk-weighted assets (RWAs): } \\
\quad \text { RWAs for market and operational risk } \\
\text { remain constant throughout the forecast period; } \\
\quad \text { RWAs for credit risk are subject to the } \\
\text { Basel I floor and sensitive to the regulatory } \\
\text { impact due to Basel III (according to QIS-6 } \\
\text { results), which increase by at least } 17.25 \text { percent } \\
\text { [4 largest banks] and } 3.1 \text { percent [other banks] } \\
\text { (independent of asset growth) between } 2013 \\
\text { and 2015, respectively; there is no regulatory } \\
\text { impact on RWAs for market risk as Belgium has } \\
\text { adopted Basel } 2.5 \text { on } 31 \text { December } 2011 \text {; in } \\
\text { addition, credit RWAs are sensitive both } \\
\text { changes in PDs and portfolio correlations: (a) } \\
\text { nonlinear effect of changes in PDs and (b) } \\
\text { concentration risk impact on RWAs. } \\
\quad \text { RWA impact of defaulted loans: The } \\
\text { risk-weights for credit risk are subsequently } \\
\text { reduced by the RWAs of defaulted exposures, } \\
\text { which are approximated by taking } 2.5 \text { times the } \\
\text { average RWAs for nondefaulted exposures }\end{array}$ \\
\hline
\end{tabular}




\begin{tabular}{|c|c|c|c|}
\hline & & $\begin{array}{l}\text { average RWAs for nondefaulted exposures } \\
\text { (accounting for the fact that risk-weights for } \\
\text { defaulted exposures were higher prior to } \\
\text { default). }\end{array}$ & $\begin{array}{l}\text { (accounting for the fact that risk-weights for } \\
\text { defaulted exposures were higher prior to } \\
\text { default). }\end{array}$ \\
\hline $\begin{array}{l}\text { 6. Reporting } \\
\text { Format for Results }\end{array}$ & Output presentation & $\begin{array}{l}\text { Basel III (Common Equity Tier 1, Tier 1, } \\
\text { Total Capital, conservation buffer) for each year } \\
\text { of the risk horizon. } \\
\text { - Firms reported capital adequacy for } \\
\text { each year over the forecast horizon based on an } \\
\text { output template provided by IMF staff. In case } \\
\text { of a capital shortfall, firms calculated the } \\
\text { recapitalization needs. Firms reported the major } \\
\text { risk drivers (profitability, credit/trading losses, } \\
\text { RWAs) and showed the marginal impact of } \\
\text { including (i) haircuts on sovereign debt } \\
\text { holdings; (ii) capital phase-in/phase-out } \\
\text { according to Basel III; and (iii) FX shocks. In } \\
\text { addition, firms reported alternative stress test } \\
\text { results without considering the restrictions on } \\
\text { the behavioral adjustment of banks as separate } \\
\text { output. }\end{array}$ & $\begin{array}{l}\text { Basel III (Common Equity Tier 1, Tier 1, } \\
\text { Total Capital, conservation buffer) for each year } \\
\text { of the risk horizon. } \\
\quad \text { Staff determined capital adequacy for } \\
\text { each year over the forecast horizon. In case of a } \\
\text { capital shortfall, recapitalization needs are } \\
\text { calculated. The major risk drivers (profitability, } \\
\text { credit/trading losses, RWAs) were identified } \\
\text { together with the marginal impact of including } \\
\text { (i) haircuts on sovereign debt holdings, and (ii) } \\
\text { capital phase-in/phase-out according to Basel } \\
\text { III. }\end{array}$ \\
\hline \multicolumn{4}{|c|}{ BANKING SECTOR: LIQUIDITY RISK } \\
\hline \multirow[t]{2}{*}{$\begin{array}{l}\text { 1. Institutional } \\
\text { Perimeter }\end{array}$} & Institutions included & $\begin{array}{l}\text { - } 6 \text { largest banks (KBC, Belfius, BNP } \\
\text { Paribas Fortis, ING Belgium, AXA Bank Europe, } \\
\text { and Argenta) [for Basel III measures (old LCR } \\
\text { and NSFR)] }\end{array}$ & $\begin{array}{l}6 \text { largest banks (KBC, Belfius, BNP } \\
\text { Paribas Fortis, ING Belgium, AXA Bank Europe, } \\
\text { and Argenta) [for Basel III measure (revised } \\
\text { LCR)] } \\
\text { foreign branches, Euroclear and Bank of NY } \\
\text { Mellon (which is a custodian bank) [for NBB } \\
\text { Liquidity Ratios] }\end{array}$ \\
\hline & $\begin{array}{l}\text { Data and baseline } \\
\text { date }\end{array}$ & $\begin{array}{l}\text { Source: institutions' own granular data. } \\
\quad \text { Date: end-June } 2012 . \\
\text { Scope: solo basis (BNP Paribas Fortis, } \\
\text { ING Belgium) and consolidated basis (KBC, } \\
\text { Belfius, AXA Bank Europe, and Argenta); only } \\
\text { unencumbered liquid assets (generating cash } \\
\text { inflows), i.e., that can be sold or used as a }\end{array}$ & $\begin{array}{l}\text { Source: supervisory data (NBB Liquidity } \\
\text { Ratios) and calculations based on institutions' } \\
\text { own granular data (revised LCR). } \\
\quad \text { Date: end-June } 2012 \text {. } \\
\text { Scope: solo and consolidated basis; } \\
\text { only unencumbered liquid assets (generating } \\
\text { cash inflows), i.e., that can be sold or used as a }\end{array}$ \\
\hline
\end{tabular}

CInternational Monetary Fund. Not for Redistribution 


\begin{tabular}{|c|c|c|c|}
\hline & & $\begin{array}{l}\text { collateral to receive funding (with the exception } \\
\text { of cash/cash-equivalents) are included in the } \\
\text { test ("liquidity scope"). }\end{array}$ & $\begin{array}{l}\text { collateral to receive funding (with the exception } \\
\text { of cash/cash-equivalents) are included in the } \\
\text { test ("liquidity scope"). }\end{array}$ \\
\hline $\begin{array}{l}\text { 2. Channels of } \\
\text { Risk Propagation }\end{array}$ & Methodology & $\begin{array}{l}\text { Definition of Basel III measures as per } \\
\text { guidance published on Dec. } 2010 \text { (including } \\
\text { assessment of haircuts on liquid assets, } \\
\text { assumption on expected and contingent cash } \\
\text { in- and outflows). }\end{array}$ & $\begin{array}{l}\text { Definition of revised LCR as per } \\
\text { guidance published on Jan. } 2013 \text { (including } \\
\text { assessment of haircuts on liquid assets, } \\
\text { assumption on expected and contingent cash } \\
\text { in- and outflows) } \\
\quad \text { Calculation of NBB Liquidity Ratio (at } \\
\text { one week and one month). }\end{array}$ \\
\hline \multirow[t]{2}{*}{ 3.Risks and Buffers } & Risks & $\begin{array}{ll} & \text { Funding liquidity. } \\
\text { - } & \text { Market liquidity. }\end{array}$ & $\begin{array}{l}\text { Funding liquidity. } \\
\text { Market liquidity. }\end{array}$ \\
\hline & Buffers & $\begin{array}{l}\text { Constant funding structure; no } \\
\text { counterbalancing capacity. } \\
\text { without having access to ECB facilities. }\end{array}$ & $\begin{array}{l}\text { Constant funding structure; no } \\
\text { counterbalancing capacity. } \\
\text { without having to respond to withdrawals } \\
\text { facilities. }\end{array}$ \\
\hline 4. Tail shocks & Size of the shock & $\begin{array}{l}\text { Bank run and dry up of wholesale } \\
\text { funding markets, taking into account haircuts to } \\
\text { liquid assets. }\end{array}$ & $\begin{array}{l}\text { Bank run and dry up of wholesale } \\
\text { funding markets, taking into account haircuts to } \\
\text { liquid assets. } \\
\quad \text { Three alternative scenarios [for NBB } \\
\text { liquidity ratio], which assume (i) the absence of } \\
\text { a deposit run, (ii) the escalation of sovereign risk } \\
\text { (requiring higher valuation haircuts for } \\
\text { collateralized funding with central banks), and } \\
\text { (iii) the absence of contingent cash inflows from } \\
\text { related parties. }\end{array}$ \\
\hline $\begin{array}{l}\text { 5. Regulatory and } \\
\text { Market-Based } \\
\text { Standards and } \\
\text { Parameters }\end{array}$ & Regulatory standards & Basel III ratios: LCR (old version), NSFR. & $\begin{array}{l}\text { Basel III ratios: LCR (new version). } \\
\text { National requirement: NBB liquidity } \\
\text { ratio (one week and one month). }\end{array}$ \\
\hline $\begin{array}{l}\text { 6. Reporting } \\
\text { Format for Results }\end{array}$ & Output presentation & Hurdle metrics: distribution of ratios. & $\begin{array}{l}\text { Hurdle metrics: distribution of ratios, } \\
\text { number of failed banks, liquidity shortfall } \\
\text { relative to unencumbered assets. }\end{array}$ \\
\hline
\end{tabular}


Table 5.3. Belgium: Macroeconomic Scenarios for Stress Testing Exercise

(Banking Sector)

\section{Economic Activity under Different Scenarios}

(percentage change from previous period, unless otherwise indicated)

\section{Real GDP}

Imports (goods and services)
Private consumption

Gross fixed capital formation

Exports (goods and services)

Inventories

Household saving ratio (\% of disp. inc.)

Baseline Scenario

\begin{tabular}{ccccc}
\hline 2013 & 2014 & 2015 & 2016 & 2017 \\
\hline $\mathbf{0 . 3}$ & $\mathbf{1 . 0}$ & $\mathbf{1 . 3}$ & $\mathbf{1 . 4}$ & $\mathbf{1 . 4}$ \\
0.2 & 0.8 & 1.0 & 1.1 & 0.9 \\
-0.1 & 1.8 & 3.2 & 3.5 & 3.5 \\
0.5 & 1.5 & 3.1 & 3.8 & 4.5 \\
0.4 & 1.5 & 3.4 & 4.1 & 4.7 \\
0.0 & 0.0 & 0.0 & 0.0 & 0.0 \\
16.2 & 16.5 & 16.7 & 17.1 & 17.6
\end{tabular}

Unemployment rate (\% of labor force)

Total employment

\section{Price and cost developments}

Consumption prices

House prices

Commercial real estate prices

Equity market index

GDP deflator

ULC, whole economy

Terms of trade

$\begin{array}{lllll}7.8 & 7.6 & 7.5 & 7.3 & 7.4 \\ 0.3 & 0.8 & 0.8 & 0.9 & 0.9\end{array}$

$\begin{array}{lllll}1.9 & 1.4 & 1.2 & 1.2 & 1.2\end{array}$
Severe Double-Dip (DD) Scenario

\begin{tabular}{lllll}
2013 & 2014 & 2015 & 2016 & 2017 \\
\hline
\end{tabular}

$\begin{array}{lllll}-1.6 & -0.4 & 0.6 & 1.0 & 1.1\end{array}$

$\begin{array}{lllll}-0.1 & 0.2 & 0.7 & 1.0 & 0.9\end{array}$

$\begin{array}{lllll}-1.8 & -0.7 & 1.7 & 2.6 & 3.1\end{array}$

$\begin{array}{lllll}-3.6 & -1.0 & 1.9 & 2.9 & 3.9\end{array}$

$\begin{array}{lllll}-1.6 & -1.0 & 1.9 & 2.9 & 3.9 \\ -1.9 & -0.3 & 2.4 & 3.3 & 4.2\end{array}$

$\begin{array}{lllll}0.0 & 0.0 & 0.0 & 0.0 & 0.0\end{array}$

$\begin{array}{lllll}15.2 & 15.9 & 16.3 & 16.7 & 17.1\end{array}$

17.1

\section{$\begin{array}{lllll}8.0 & 8.6 & 9.3 & 9.7 & 10.3\end{array}$}

$\begin{array}{ccccc}8.0 & 8.6 & 9.3 & 9.7 & 10.3 \\ 0.1 & -0.1 & -0.1 & 0.2 & 0.3\end{array}$

$\begin{array}{lllll}3.8 & 2.6 & 2.0 & 1.7 & 1.4\end{array}$

$\begin{array}{ll}3.8 & 2.6 \\ -2.0 & -0.7\end{array}$

$\begin{array}{lll}0.8 & 1.2 & 1.5 \\ 0.8 & 1.2 & 1.5\end{array}$

$\begin{array}{lllll}-20.9 & -1.7 & 0.8 & 1.2 & 1.5\end{array}$

$\begin{array}{llll}0.2 & 0.1 & 1.0 & 1.4\end{array}$

$\begin{array}{lllll}2.3 & 2.7 & 2.0 & 1.8 & 1.5\end{array}$

$\begin{array}{lllll}4.3 & 4.1 & 2.8 & 1.8 & 1.9\end{array}$

$\begin{array}{lllll}-1.3 & 0.3 & 0.0 & 0.1 & 0.2\end{array}$

\section{Interest rates}

short-term interest rate (In percent) [EONIA]

short-term interest rate (In percent) [3-month T-bill]

10-year sovereign bond yield (In percent)

$\begin{array}{lllll}0.4 & 0.4 & 0.4 & 0.4 & 0.4 \\ 0.9 & 0.9 & 0.9 & 0.9 & 0.9 \\ 3.1 & 3.4 & 3.6 & 3.8 & 3.8\end{array}$

$\begin{array}{lllll}1.0 & 1.0 & 0.9 & 0.9 & 0.8 \\ 1.3 & 1.5 & 1.7 & 1.9 & 1.9 \\ 3.3 & 3.6 & 3.8 & 3.9 & 3.9\end{array}$

Slow Growth (SG) Scenario

\begin{tabular}{lllll}
2013 & 2014 & 2015 & 2016 & 2017 \\
\hline
\end{tabular}

$\begin{array}{lllll}-0.6 & 0.1 & 0.4 & 0.5 & 0.5\end{array}$

$\begin{array}{lllll}0.1 & 0.5 & 0.7 & 0.9 & 0.7\end{array}$

\begin{tabular}{llll}
3.4 & 3.6 & 3.8 & 3.8 \\
\hline
\end{tabular}

\begin{tabular}{lllll}
0.4 & 0.4 & 0.4 & 0.3 & 0.3 \\
0.9 & 0.9 & 0.9 & 0.6 & 0.6 \\
3.0 & 3.3 & 3.5 & 3.8 & 3.8 \\
\hline
\end{tabular}




\begin{tabular}{|c|c|c|c|c|}
\hline \multicolumn{5}{|c|}{$\begin{array}{l}\text { Table 5.4. Belgium: Liquidity Stress Test Parameters } \\
\text { (Basel III Measures) }\end{array}$} \\
\hline \multirow[t]{2}{*}{$\overline{\text { Test }}$} & Definition & Asset Side (cash inflows) & \begin{tabular}{|l} 
Basic Assumptions \\
Liabilities (cash outflows)
\end{tabular} & Other Assumptions \\
\hline & \multicolumn{4}{|c|}{ Proposed Basel III Standard Measures } \\
\hline $\begin{array}{l}\text { Liquidity Coverage Ratio (LCR): } \\
\text { short-term resilience to potential } \\
\text { liquidity disruptions [old } \\
\text { version, Dec. 2010] }\end{array}$ & $\begin{array}{l}\text { Stock of high-quality } \\
\text { liquid assets would } \\
\text { need to cover 30-day } \\
\text { net cash outflows }\end{array}$ & 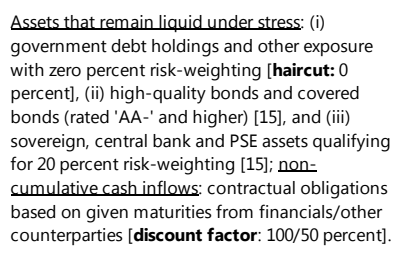 & 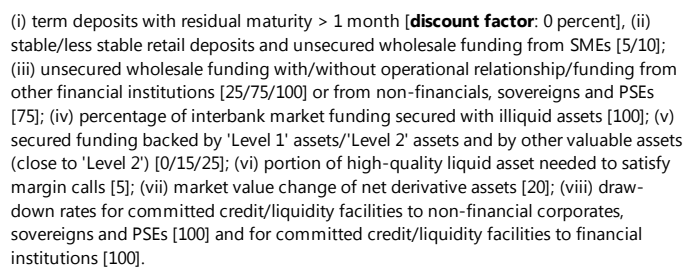 & $\begin{array}{l}\text { Bank assumptions on collateralized assets maturing within } 30 \\
\text { days, portion of assets reinivested, and renewal rate for amortizing } \\
\text { loans and other assets; no inflows from new or the renewal of } \\
\text { interbank lending in times of stress, and no consideration of } \\
\text { accesss to ECB Bifuidity on the basis of non-LCR buffer eligible } \\
\text { assets; cash inflows limited to } 75 \text { percent of cash outfllows. }\end{array}$ \\
\hline $\begin{array}{l}\text { Liquidity Coverage Ratio (LCR): } \\
\text { short-term resilience to potential } \\
\text { liquidity disruptions [revised } \\
\text { version, Jan. 2013] - adapted to } \\
\text { liquidity reporting by banks to } \\
\underline{\text { NBB }}\end{array}$ & $\begin{array}{l}\text { Stock of high-quality } \\
\text { liquid assets would } \\
\text { need to cover 30-day } \\
\text { net cash outflows }\end{array}$ & 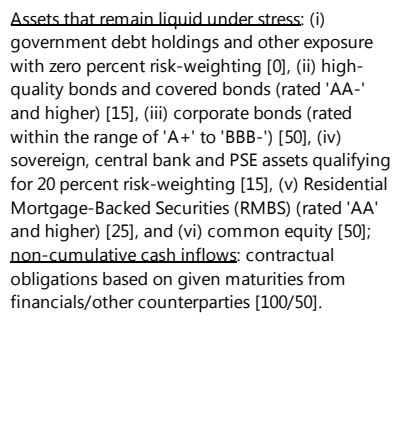 & 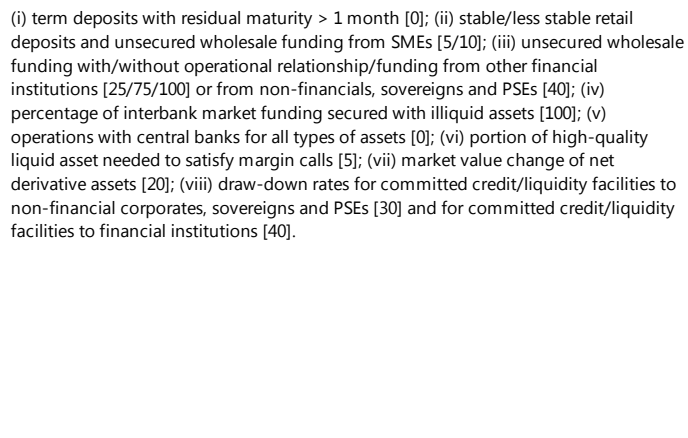 & 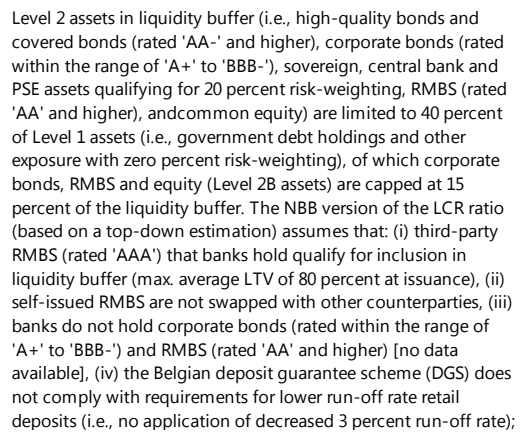 \\
\hline $\begin{array}{l}\text { Net Stable Funding Ratio } \\
\text { (NSFR): long-term structural } \\
\text { ratio to address liquidity } \\
\text { mismatches }\end{array}$ & $\begin{array}{l}\text { Amount of available } \\
\text { stable funding to } \\
\text { exceed the level of } \\
\text { required funding }\end{array}$ & 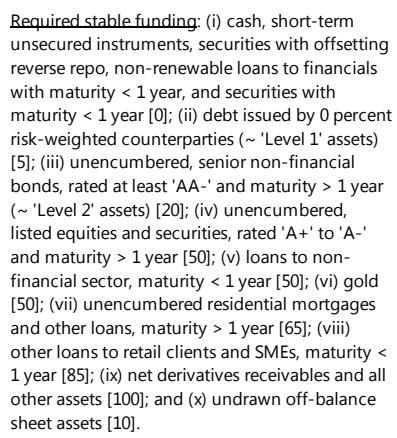 & $\begin{array}{l}\text { Available stable funding: (i) capital and long-term debt ( }>1 \text { year) [100], (ii) 'stable } \\
\text { deposits' of retail and SMEs }(<1 \text { year) [90], (iii) 'less stable' deposits of retail and SMEs } \\
\text { < } 1 \text { year) [80], (iv) whholesale funding provided by non-financials }(<1 \text { year) [50], and } \\
\text { (v) all other liabilities [0]. }\end{array}$ & $\begin{array}{l}\text { No inflows of interbank lending in times of stress; no } \\
\text { consideration of access to ECB liquidity on the basis of non- } \\
\text { eligible assets. }\end{array}$ \\
\hline
\end{tabular}




\begin{tabular}{|c|c|c|c|c|}
\hline \multicolumn{5}{|c|}{$\begin{array}{l}\text { Table 5.5. Belgium FSAP Update: Liquidity Stress Test Parameters } \\
\text { (NBB Liquidity Ratio) }\end{array}$} \\
\hline \multirow[t]{2}{*}{$\begin{array}{l}\text { Test } \\
\end{array}$} & Definition & \multicolumn{2}{|l|}{ Basic Assumptions } & Other Assumptions \\
\hline & \multicolumn{4}{|c|}{ NBB Liquidity Ratio } \\
\hline One-week horizon & $\begin{array}{l}\text { One-off aggregate } \\
\text { outflow of liabilities } \\
\text { for } 1 \text { week }\end{array}$ & 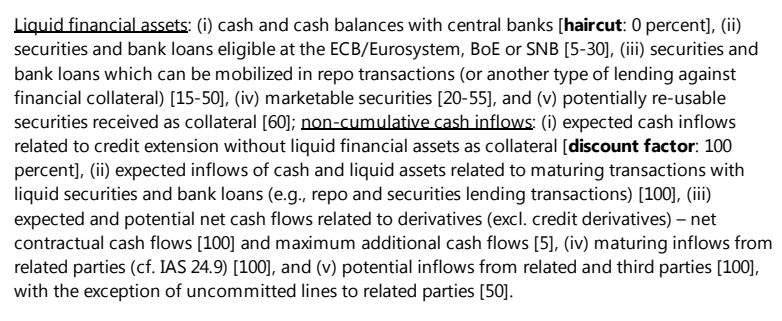 & $\begin{array}{l}\text { (i) cash outtlows related to maturing and non-maturity funding } \\
\text { without liquid financial assets as collateral [discount factor: } 100 \\
\text { percent] (i.e., all deposits and funding from financial and non- } \\
\text { financial corporate, sovereign and other public sector and central } \\
\text { bank clients) with the exception of sight deposit and regulated } \\
\text { savings deposits from private households or SME clients [5], (ii) } \\
\text { expected outflows of cash and liquid assets related to } \\
\text { transactions with liquid securities and bank loans (e.g., repo and } \\
\text { securities lending transactions) [100], (iii) maturing outflows to to } \\
\text { related parties (cf. IAS 24.9) [100], and (v) contingent claims to } \\
\text { related and third parties [5], with the exception of uncommitted } \\
\text { credit lines to related and third parties [2.5]. }\end{array}$ & 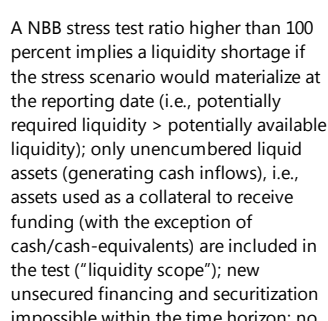 \\
\hline One month horizon & $\begin{array}{l}\text { One-off aggregate } \\
\text { outflow of liabilities } \\
\text { for } 1 \text { month }\end{array}$ & $\begin{array}{l}\text { Liquid financial assets: (i) cash and cash balances with central banks [0], (ii) securities and bank } \\
\text { loans eligible at the ECB/Eurosystem, BoE or SNB [5-30], (iii) securities and bank loans which } \\
\text { can be mobilised in repo transactions (or another type of lending against financial collateral) } \\
\text { [15-50], (iv) marketable securities [20-55], and (v) potentially re-usable securities received as } \\
\text { collateral [60]; non-cumulative cashinflows: (i) expected cash inflows related to credit } \\
\text { extension without liquid financial assets as collateral [100], (ii) expected inflows of cash and } \\
\text { liquid assett related to maturing transactions with liquid securities and bank loans (e.g., repo } \\
\text { and securitites lending transactions) [1000,, (iii) expected and potential net cash flows related to } \\
\text { derivatives (excl. credit derivatives) - net contractual cash flows [100] and maximum additional } \\
\text { cash flows [15], (iv) inflows from related parties (cf. IAS 24.9) [100], and (v) potential inflows } \\
\text { from related and third parties [100], with the exception of uncommitted lines to related parties } \\
{[50] \text {. }}\end{array}$ & $\begin{array}{l}\text { (i) cash outtlows related to maturing funding without liquid } \\
\text { financial assets as collateral, with the exception of sight deposit } \\
\text { and regulated savings deposits [100] (i.e., all deposits and funding } \\
\text { from financial and non-financial corporate, sovereign and other } \\
\text { public sector and central bank clients) with the exception of sight } \\
\text { deposit and regulated savings deposits from private households } \\
\text { or SME clients [20], (ii) expected outflows of cash and liquid } \\
\text { assets related to transactions with liquid securities and bank loans } \\
\text { (e.e.g. repo and securities lending transactions) [100], (iv) maturing } \\
\text { outflows to related parties (c. IAS 24.9) [100], and (v) contingent } \\
\text { claims to related and third parties [15], with the exception of } \\
\text { uncommitted credit lines to related and third parties [7.5]. }\end{array}$ & $\begin{array}{l}\text { offsetting cash inflows from new or } \\
\text { renewed wholesale lending (at } \\
\text { contractual maturities); ; entral bank } \\
\text { eligible collateral can be monetized at } \\
\text { appropriate haircuts; repo markets are } \\
\text { open at appropriate haircuts; fire-sale } \\
\text { of assets possible at appropriate } \\
\text { haircuts; re-use of collateral received } \\
\text { possible at appropriate haircuts; } \\
\text { potential unsecured support in } \\
\text { convertible currencies only from related } \\
\text { parties (e.g., in the form of committed } \\
\text { lines); no renewal of term retail and }\end{array}$ \\
\hline $\begin{array}{l}\text { NBB Liquidity Ratio } \\
\text { (one month only) } \\
\text { (alternative scenarios) }\end{array}$ & & \multicolumn{2}{|c|}{$\begin{array}{l}\text { Scenarios (one month): like above, with the exception of: } \\
\text { (i) "no deposit run scenario": non-cumulative cash outflows from private sector deposits [from } 20 \text { to o]; } \\
\text { (ii) "no intergroup funding scenario": potential non-cumulative cash inflows from committed lines with related parties [from } 100 \text { to o]; and } \\
\text { (iii) "rising sovereign risk scenario": increase of haircuts on liquid assets: bonds issued by central governments or central banks eligible at ECB/Eurosystem, BoE or } \\
\text { SNB [from } 5 \text { to 7.5]. }\end{array}$} & $\begin{array}{l}\text { wholesale deposits; and full } \\
\text { convertibility between currencies } \\
\text { (within time frame of one week). }\end{array}$ \\
\hline
\end{tabular}




\section{Annex I. Report on the Observance of Standards and Codes (ROSCs)-Summary Assessments}




\section{BASEL CORE PRINCIPLES FOR EFFECTIVE BANKING SUPERVISION}

\section{A. Background}

1. The Belgian financial system is relatively large, concentrated, and interconnected, with solid capital buffers on aggregate. Post 2008 , an initial deleveraging significantly reduced the size of the system, with a second, slower wave of deleveraging, currently underway. Four dominant banking groups represent almost $3 / 4$ of consolidated system assets. Assets of foreign-owned banks account for over half of the sector. The links between banks and the Belgian sovereign have intensified due to the crisis, with total exposure of the banking sector to the federal government at 10 percent of banking sector assets in mid-2012. Tier 1 capital ratio has risen from 11.6 percent of risk-weighted assets in 2008 to 14.8 percent in mid 2012 on aggregate, comparing favorably to other major international banking systems.

\section{Domestic economic challenges and sovereign risk perceptions remain sources of} continued uncertainty as the banking sector consolidates. The outlook for economic growth remains weak. Banks have struggled for profitability since the crisis, and structural costs remain high. A wide and stable deposit base has limited rollover risks and strategic re-orientation of the banking sector towards the domestic markets has prevented a disproportionate decline in credit supply. There are, however, downside risks to asset quality, even though the overall level of impairments has remained relatively benign so far.

3. The regulatory and supervisory regime has been re-organized in 2011 . The new architecture replaced the integrated regulator (the CBFA) and allocated the prudential supervision of financial institutions to the NBB and the responsibility for ensuring market conduct and consumer protection to the FSMA. All bank and insurance supervision staff moved to the NBB.

\section{B. NBB Approach to Supervision}

4. Belgium has a well developed public infrastructure supporting effective banking supervision. Belgium has a complete system of business laws, consistently enforced. The Belgian legal system is based on civil law. The legislative branch is composed of a parliament with two chambers (Chamber and Senate). Belgium has a constitutional monarchy whereby the King is the head of state and of the executive branch. The judicial branch is independent with a hierarchy of courts, the most senior of which is the Court of Cassation, the supreme judicial court. As a member of the EU, much domestic legislation, including banking regulation, derives from EU regulations, directives and decisions, which are frequently updated to keep pace with international standards.

\section{Belgium has a high level of compliance with the Basel Core Principles for Effective} Banking Supervision (BCPs). This high level of compliance has been achieved in a challenging environment with persisting elevated stress and vulnerabilities. Added to this are the forthcoming higher regulatory standards, most notably in capital and liquidity. These conditions put a premium 
on both the quality of risk management practices within the banks themselves and the supervisory oversight conducted by the authorities. In addition to substantial regulatory changes, the supervisory authorities have also had to adjust to the challenges of transition wrought by re-design of the regulatory architecture and the move of prudential supervision to the central bank.

\section{The NBB deploys high-quality supervisory practices-which it is building upon} through well conceived initiatives and reforms-but there are weaknesses in its supervisory process. The NBB has already instituted some enhancements to its risk oversight, such as an annual risk review, and is executing a focused but multi-faceted plan of improvements. These projects will integrate processes, create greater flexibility in data handling and strengthen analysis at firm specific and horizontal levels.

\section{Assessment Challenges}

\section{This assessment provides an update on the significant regulatory and supervisory} developments in the banking sector of Belgium since 2004. The assessment is carried under the BCP methodology of 2006. It reflects the regulatory and supervisory framework in place at the time of the assessment. Importantly, it is not intended to assess the merits of the important policy and implementation issue regarding several aspects of the international regulatory framework that are yet to be decided in international fora, the EU, and in Belgium, ranging from the finalization of Basel III implementation in Europe to the potential creation of a Single Supervisory Mechanism. An assessment of the effectiveness of banking supervision requires a review of the legal framework, both generally and as specifically related to the financial sector, and detailed examination of the policies and practices of the institutions responsible for banking regulation and supervision. In line with the BCP methodology, the assessment focused on the major banks and banking groups, and their regulation and supervision, given their importance to the system.

\section{Preconditions for Effective Supervision}

8. The preconditions for effective supervision (a stable macroeconomic environment, sound legal and accounting framework, and effectiveness of procedures for the efficient resolution of problems in the securities market) appear to be in place in Belgium.

\section{E. Main Findings}

\section{Objectives independence, powers, transparence, and cooperation (CP 1)}

9. The NBB has a clear legal power to conduct prudential supervision. Similarly the NBB has a legal mandate to detect threats to financial stability. The legal mandate does not, however, clarify the relationship between the discharge of the NBB's supervisory function and of its financial stability function and how the balance of priorities should be achieved should a potential conflict emerge. It is recommended that greater legal clarity be provided, should a revision to the NBB Organic Law be undertaken, and that the NBB should develop and publish a mission statement of its objectives irrespective of legal changes. 
10. The NBB has clear lines of accountability, transparency and separate funding when acting in its supervisory capacity. There is no evidence of interference with the operational independence of the supervisor. Supervisory resources are stretched and this is of concern given the continued stress within the financial system and the importance of planned enhancements to practices and processes that the NBB is urgently seeking to roll out. The NBB is encouraged to scrutinize its plans to determine that it has robustly adequate resource to deliver its multiple supervisory projects and day-to-day supervisory practice. Contingency planning in resource is also important as there may be demands arising from major EU developments such as the Banking Union and from the possibility of crisis issues re-emerging in supervised institutions.

11. The NBB operates within a clear and balanced legal framework. The NBB Organic Law and Banking Law cover authorization and ongoing standards of supervision. Additionally, the NBB enjoys a range of remedial measures that allow for an appropriate degree of proportionality in its approach to breaches of laws and regulations. The Banking Law (Article 57) usefully takes into consideration that there may be a necessity for swift action in urgent situations. The extensive powers to authorize the disposal of the assets or liabilities of an institution are balanced by the need to obtain ratification of such measures through a Royal Decree. Appropriate legal protections have been put in place in respect of banking supervision and supervisors.

\section{The general framework for exchange of information is well articulated but} coordination at a domestic level is yet to be fully put in place. The NBB's international relationships are supported by operational agreements and are working fluently. Domestic working level cooperation needs to be underpinned and promoted by an MOU to ensure the modalities of cooperation between the NBB and the FSMA. Amendments to the Twin Peaks Law to rectify drafting oversights in relation to the gateway for the exchange of information between the FSMA and the NBB, which were planned for the end of 2012, are also desirable and should be concluded.

\section{Licensing and structure (CPs 2-5)}

13. The legal framework for authorization, on-going standards for supervision and for permissible activities is clearly stated. Both the NBB and the FSMA have legal responsibility for ensuring that the public is not misled into placing deposits with nonauthorized institutions. The NBB is to be commended on its thorough and thoughtful review of fit and proper policies and practices, which ought to confirm that fit and proper standards must be met on a continuous basis. The widening of the formal scope of application of the fit and proper assessment to include key personnel such as the heads of compliance, internal audit and risk management, in cases where these individuals do not form part of the senior management is, similarly, good practice.

\section{The change of control of a credit institution and a major acquisition by a credit} institution is, broadly, well governed by the laws. The NBB has comprehensive legal powers surrounding the governance and scrutiny of major acquisitions by supervised firms, in particular for systemically relevant institutions. For nonsystemic firms, however, it is recommended that the NBB establish either pre-notification or pre-approval thresholds for acquisitions in nonfinancial entities. 


\section{Prudential regulation and requirements (CPs 6-18)}

\section{Belgian banks have undergone considerable stress over recent years and have} increased the level and, importantly, the quality of capital in CET1. The Tier 1 capital ratios range between 11.5 percent and 20.6 percent for the systemically important banks as at March 2012 . The capital ratios in these banks have a high share of CET1, which has been gradually increasing, despite severe stress from the crisis requiring state intervention and support. There has also been a run off of Tier 2 instruments in anticipation of Basel III implementation. Nonetheless, increased minimum capital adequacy requirements under Basel III will continue to be challenging for some banks due to a stricter definition of capital, deductions from the capital base etc.

16. The NBB's approach to Pillar 2 is well developed using a scorecard as the primary tool for risk analysis, taking into account qualitative and quantitative measures. At least annually, the NBB determines the minimum capital adequacy requirements for all banks on a forward looking basis. The SREP and ICAAP analysis are main inputs into the process and, if available, outputs from banks' economic capital models. Stress testing probes the resilience of capital buffers.

17. Senior management of the bank must submit an annual self assessment of the control environment to the NBB. The external auditor provides a factual evaluation of management's self assessment but this is not a positive assurance on the design and effectiveness of controls. As a result, the external auditor's report will not necessarily identify any hidden build-up of risks or provide a positive assurance on the quality of risk management. Without on-site review the NBB should place limited reliance on this report, which it uses as an input to activities, such as the ICAAP.

\section{Annual meetings with the full Board of Directors should form an integral component} of the NBB's standard supervision practice. Annual meetings between the NBB and the full Board (including nonexecutive independent directors) should be mandatory for all banks. The meeting will help the NBB assess the role of the Board in overseeing management to ensure that policies, processes and systems are implemented effectively at all decision levels. Currently there are frequent meetings with Board members, but there is room for formalizing a minimum supervisory standard.

\section{Large exposure limits have been strengthened recently but warrant further overhaul} for small institutions. EU legislation calculates exposures as net of eligible credit risk mitigation and sets a hard limit of 25 percent of own funds for an exposure to an individual or connected group of counterparties. Recent EU amendments (Directive 2009/111/EC), affect smaller firms with own funds below $€ 600$ million permitting a limit of 25 percent of own funds or $€ 150$ million, whichever is the higher, for exposures to institutions. The sum of exposures to all connected clients that are not institutions must not exceed 25 percent of own funds, however. Where $€ 150$ million is the higher limit, the value of the exposure shall not exceed a reasonable limit to be determined by credit institutions, though must not be higher than 100 percent of the credit institution's own funds.

20. Liquidity regime is well embedded. The systemic banks must report liquidity daily in addition to a weekly meeting and monthly liquidity stress test. While the definition of eligible liquid assets is broader than the Basel LCR definition, the run-off assumptions for liabilities are more 
stringent. The stress test was introduced in 2009 as an observation ratio with full implementation from 2011. The liquidity stress test will help smooth the transition to Basel LCR for banks in 2015. The authorities are advised to keep the current regime in place until a full implementation of LCR in the EU to preserve banks' liquidity buffers.

\section{The requirements for managing interest rate risk in the banking book are well} established in the regulatory framework. The NBB has made strong efforts to implement new standards and has embedded interest rate risk in its core work. Interest rate risk stress test ratios require banks to hold sufficient capital to cover economic value losses related to adverse structural interest rate changes prescribed by the NBB. While the ratios provide a consistent measure of interest rate risk across banks, the ratios do not always fully capture bank specific risks. When evaluating minimum capital ratios, interest rate risk is taken into account as a Pillar 2 risk.

\section{Methods of ongoing banking supervision (CPs 19-20)}

\section{The supervisory staff are conducting high quality risk based supervision both on and} off-site. The NBB has sound analytical processes that it is refreshing and deepening and which will emphasize forward looking perspectives. The new tools should further support the dialogue between the institutions and the supervisors. Continued incorporation of insurance risk within the global group risk assessments is important and should also be enhanced, as planned. The NBB has restructured on-site supervision and ensured effective coordination with the off-site teams.

23. The NBB applies a comprehensive supervisory program to the systemic firms but must ensure that "globally balanced supervisory planning" covers all supervised firms. The NBB needs a risk based approach to its supervisory process to ensure that each institution systematically receives the appropriate intensity of supervisory attention proportionate to its profile. Such a plan should provide a structured framework to guide decision making in terms of which actions should be postponed or performed less frequently, and which institutions should be affected when new or urgent priorities emerge that demand the reallocation of scarce supervisory resource.

\section{Reporting, accounting and disclosure (CPs 21 -22)}

24. In Belgium, the external auditor of a bank is accredited by the NBB. The external auditor is accredited directly by the NBB if satisfying standards for independence, experience, competence and organization. The external auditor provides an audit opinion on the financial accounts (six monthly and annually) as well as regarding the self assessment performed by management annually on the internal control environment and on the reliability of prudential returns.

\section{Under NBB rules, banks are required to report on a solo and, if part of a group,} consolidated basis. Belgium accounting rules (Belgium GAAP) apply on a solo basis and IFRS on a consolidated basis if they have to produce consolidated accounts according to EU directives. Banks submit quarterly prudential returns of key data such as capital adequacy, balance sheet, earnings etc. Liquidity is reported more frequently on a monthly basis. 


\section{Corrective and remedial powers of supervisors (CP 23)}

26. The NBB enjoys a broad range of powers for corrective and remedial measures and there is evidence that the NBB is able and ready to use such remedies. On occasion, the threat of using these powers was sufficient to obtain the desired outcome. The NBB is examining the possibility of making its disciplinary powers more graduated, in particular through the use of fines.

\section{Consolidated and cross border banking supervision (CPs 24-25)}

27. The NBB has the necessary legal powers and has implemented regulatory structures to facilitate consolidated supervision. Given the significance of cross border activities for the systemic groups in Belgium, the NBB has focused on work within the EU supervisory colleges. The NBB is actively using the college environment to test out the quality of risk focused management within groups as well as to ensure an adequate distribution of capital within the group.

28. The NBB places great value on and is strongly motivated to contribute to and participate in home-host relationships as fully and as effectively as possible. Cooperation arrangements and MOUs are in place with all relevant jurisdictions. Home and host relationships are critical to the successful supervisory oversight of the financial system in Belgium. While EU legislation imposes requirements including joint assessment and decision making processes on EU supervisory colleges, the quality of execution depends on the supervisory authorities.

29. Table 1 offers a principle-by-principle summary of the assessment results, while recommendations to improve compliance with the BCPs are summarized in Table 2. 
Table 1. Summary Compliance with the BCPs

\begin{tabular}{|c|c|}
\hline Core Principle & Comments \\
\hline \multicolumn{2}{|l|}{$\begin{array}{l}\text { 1. Objectives, independence, powers, } \\
\text { transparency, and cooperation }\end{array}$} \\
\hline 1.1 Responsibilities and objectives & $\begin{array}{l}\text { There could be greater clarity and transparency in } \\
\text { terms of the relationship between the supervisory and } \\
\text { financial stability goals of the NBB. }\end{array}$ \\
\hline $\begin{array}{l}1.2 \text { Independence, accountability and } \\
\text { transparency }\end{array}$ & $\begin{array}{l}\text { It is not mandatory to publicly disclose the reasons for } \\
\text { the dismissal of the Governor of the NBB. Staff } \\
\text { resources are over-stretched at a time of elevated } \\
\text { stress, so capacity to respond to deteriorating } \\
\text { conditions may be jeopardized. The limited rule } \\
\text { making powers are subject to potential veto by the } \\
\text { government. }\end{array}$ \\
\hline 1.3 Legal framework & $\begin{array}{l}\text { The NBB operates within a clear legal framework. See } \\
\text { also CP } 1.2\end{array}$ \\
\hline 1.4 Legal powers & Supervisors have a broad range of powers. \\
\hline 1.5 Legal protection & $\begin{array}{l}\text { Appropriate legal protections are in place in respect of } \\
\text { banking supervision and supervisors. }\end{array}$ \\
\hline 1.6 Cooperation & $\begin{array}{l}\text { The framework for exchange of information is well } \\
\text { articulated and appears to be operational. Cooperation } \\
\text { agreements between the NBB and the FSMA need to } \\
\text { be finalized and acted on. }\end{array}$ \\
\hline 2. Permissible activities & The laws provide clear definitions. \\
\hline 3. Licensing criteria & $\begin{array}{l}\text { The NBB has sound practices and has been reviewing } \\
\text { its regime for assessing "fit and proper." }\end{array}$ \\
\hline 4. Transfer of significant ownership & $\begin{array}{l}\text { The NBB's policies and procedures are comprehensive } \\
\text { and there is an increasing focus on looking "upwards" } \\
\text { through the shareholding and ownership structure } \\
\text { above the institution. }\end{array}$ \\
\hline 5. Major acquisitions & $\begin{array}{l}\text { The NBB has powers to object to strategic decisions by } \\
\text { systemic firms and meets this principle for such firms. } \\
\text { However, nonsystemic firms could make a major } \\
\text { acquisition in a nonfinancial sector without either pre- } \\
\text { notification or pre-approval. }\end{array}$ \\
\hline 6. Capital adequacy & $\begin{array}{l}\text { Investment in insurance subsidiaries is deducted } \\
100 \text { percent from total capital, consistent with EU law } \\
\text { but not Basel II which requires deduction 50:50 from } \\
\text { Tier } 1 \text { and Tier 2. This treatment is relevant for } \\
\text { Belgium's largest domestic consolidated banks but will } \\
\text { be modified to align with Basel II from 2013. The NBB } \\
\text { plans to apply the Basel III treatment of participations } \\
\text { in insurance companies in the future. } \\
\text { Belgian banks may lend to shareholders to subscribe } \\
\text { to the capital of the bank where repayment of the loan } \\
\text { depends on the dividends received from the capital } \\
\text { instrument. This practice means that capital is not able }\end{array}$ \\
\hline
\end{tabular}




\begin{tabular}{|c|c|}
\hline & $\begin{array}{l}\text { to absorb losses and cannot be classified as 'paid up'. } \\
\text { It also means published capital adequacy ratios of } \\
\text { banks are artificially inflated, weakening the } \\
\text { transparency of the true loss absorbency of capital. The } \\
\text { regulation has been amended to address this issue } \\
\text { with a transition period from January } 1,2014 \text {, but at } \\
\text { the time of the mission, capital figures included } \\
\text { instruments funded in this manner. }\end{array}$ \\
\hline 7. Risk management process & $\begin{array}{l}\text { CP7 focuses on Board oversight of risk management } \\
\text { policies and processes and requires the supervisor to } \\
\text { assess the Board's involvement in this function. } \\
\text { While regulations require Boards to approve risk } \\
\text { management strategies and the ICAAP, the supervisory } \\
\text { assessment of the Board's involvement and } \\
\text { understanding will not necessarily involve annual direct } \\
\text { engagement with the full Board (independent } \\
\text { nonexecutive directors), even for systemic banks. } \\
\text { Without direct engagement with and challenge to the } \\
\text { full Board the supervisor cannot form a comprehensive } \\
\text { view of the Board's oversight of risk management. }\end{array}$ \\
\hline 8. Credit risk & $\begin{array}{l}\text { There is no requirement for major credit risk } \\
\text { exposures, over a pre-defined level, to be decided by } \\
\text { the bank's senior management or Board. Critical credit } \\
\text { decisions can therefore be made by bank officers who } \\
\text { may not be fully informed of all risks. }\end{array}$ \\
\hline 9. Problem assets, provisions, and reserves & $\begin{array}{l}\text { Accounting standards govern the preparation and } \\
\text { presentation of general purpose, publicly disclosed } \\
\text { financial statements by banks. }\end{array}$ \\
\hline 10. Large exposure limits & $\begin{array}{l}\text { The LE regime permits a significant concentration risk } \\
\text { for smaller banks who may exceed the } 25 \text { percent limit } \\
\text { up to } 100 \text { percent of own funds if the exposure is less } \\
\text { than } 150 \text { million euro. The gross exposure, not taking } \\
\text { into account credit risk mitigation can be even higher. } \\
\text { Smaller banks are typically less able to raise additional } \\
\text { equity and may not have the quality of reporting and } \\
\text { risk management (such as real time exposure } \\
\text { reporting) to make timely decisions. }\end{array}$ \\
\hline 11. Exposure to related parties & $\begin{array}{l}\text { There is no single regulation or integrated process to } \\
\text { identify, monitor and report exposures to related } \\
\text { parties approved by the board. Requirements are } \\
\text { instead applied through a number of regulations that } \\
\text { mitigate this risk. }\end{array}$ \\
\hline 12. Country and transfer risks & $\begin{array}{l}\text { The NBB has not issued specific guidance on country } \\
\text { and transfer and has not imposed any more specific } \\
\text { reserves against such risks. }\end{array}$ \\
\hline 13. Market risks & $\begin{array}{l}\text { The regulatory framework has been updated to include } \\
\text { the Basel II.5 enhancements. Post-crisis, Belgian banks' } \\
\text { trading activities. Value-at-risk is the main risk } \\
\text { management tool used to limit positions. }\end{array}$ \\
\hline 14. Liquidity risk & The regulatory requirements for liquidity risk are \\
\hline
\end{tabular}




\begin{tabular}{|c|c|}
\hline & $\begin{array}{l}\text { relatively well advanced with a quantitative test similar } \\
\text { to the Basel LCR in place since } 2011 \text {. Daily reporting for } \\
\text { larger systemic banks is robust. Follow-up of the self } \\
\text { assessment process has not been conduced across all } \\
\text { banks in the sector. }\end{array}$ \\
\hline 15. Operational risk & $\begin{array}{l}\text { The frequency of on-site assessments is risk-based and } \\
\text { annual for systemic firms. For medium sized and small } \\
\text { banks, the frequency varies between one and four } \\
\text { years. Quantitative and qualitative information is } \\
\text { included in offsite analysis and used in the } \\
\text { scorecarding process. }\end{array}$ \\
\hline 16. Interest rate risk in the banking book & $\begin{array}{l}\text { The prudential requirements for managing interest rate } \\
\text { risk in the banking book are well established in the } \\
\text { regulatory framework. The NBB has made strong } \\
\text { efforts to implement new standards and has } \\
\text { embedded interest rate risk in its core work. }\end{array}$ \\
\hline 17. Internal control and audit & $\begin{array}{l}\text { The supervisory model places reliance on the credit } \\
\text { institution and the external auditor to assess the } \\
\text { control environment. The frequency, depth and } \\
\text { comprehensiveness of the supervisors testing of the } \\
\text { internal control environment should be enhanced. }\end{array}$ \\
\hline 18. Abuse of financial services & $\begin{array}{l}\text { The last FATF Mutual Evaluation Report was in June } \\
\text { 2005, and the next is due in } 2014 \text {. The level of } \\
\text { compliance of the AML/CFT regulation and guidance } \\
\text { with the relevant Recommendations appears to be very } \\
\text { satisfactory in the } 2005 \text { report. } \\
\text { The BCP assessment of the NBB's integration of } \\
\text { AML/CFT processes into supervisory practice could not } \\
\text { conclude that AML/CFT compliance is sufficiently } \\
\text { embedded in the supervisory framework. It is unclear } \\
\text { how monitoring of compliance is undertaken for } \\
\text { smaller banks that are subject only infrequently to on- } \\
\text { site inspections. }\end{array}$ \\
\hline 19. Supervisory approach & $\begin{array}{l}\text { The NBB has a sound analytical process that it is } \\
\text { refreshing and deepening in terms of analytical insight } \\
\text { and IT capabilities. The new supervisory tools ought to } \\
\text { support a more forward looking analysis and also } \\
\text { integrate analysis of insurance risk into the global risk } \\
\text { assessment of groups. }\end{array}$ \\
\hline 20. Supervisory techniques & $\begin{array}{l}\text { The NBB applies a comprehensive supervisory program } \\
\text { to systemic firms but does not yet have a process to } \\
\text { identify the proportionate level of supervisory intensity } \\
\text { for nonsystemic firms. The NBB needs to be certain } \\
\text { that it has correctly identified minimum levels of } \\
\text { supervisory activity and is capable of monitoring and } \\
\text { updating its plans as circumstances change. The NBB } \\
\text { has embarked on multiple projects to support a } \\
\text { successful outcome. }\end{array}$ \\
\hline
\end{tabular}




\begin{tabular}{|l|l|}
\hline 21. Supervisory reporting & $\begin{array}{l}\text { Belgium has a well developed system for assessing } \\
\text { prudential returns. Financial analysis takes place in } \\
\text { integrated supervisory teams, mainly on a quarterly } \\
\text { basis, and feeds into peer group comparison and } \\
\text { suggested supervisory action. }\end{array}$ \\
\hline 22. Accounting and disclosure & $\begin{array}{l}\text { Belgian GAAP applies at a solo level and IFRS for } \\
\text { consolidated accounts. There is no concrete plan to } \\
\text { harmonize accounting methodologies. The different } \\
\text { treatment for valuations might create some lack of } \\
\text { consistency in comparing risk profiles. }\end{array}$ \\
\hline $\begin{array}{l}\text { 23. Corrective and remedial powers of } \\
\text { supervisors }\end{array}$ & $\begin{array}{l}\text { The NBB has wide powers of remedial and corrective } \\
\text { action and there is evidence that it is prepared to use } \\
\text { such powers. Planned legal changes to permit the NBB } \\
\text { Board to apply periodic penalty payments will be a } \\
\text { useful additional power. }\end{array}$ \\
\hline 24. Consolidated supervision & $\begin{array}{l}\text { The NBB has the legal powers and has implemented } \\
\text { the necessary regulatory structure to facilitate the } \\
\text { practice of consolidated supervision. The NBB has } \\
\text { continued to develop its working relationships with key } \\
\text { supervisory authorities to ensure the quality of group } \\
\text { oversight of the systemic firms in particular. }\end{array}$ \\
\hline 25. Home-host relationships & $\begin{array}{l}\text { Cooperation agreements and MOUs have been made } \\
\text { with all relevant authorities and an increasingly mature } \\
\text { dialogue, information exchange and joint activities are } \\
\text { being undertaken. }\end{array}$ \\
\hline
\end{tabular}


Table 2. Recommendations to Improve Compliance with the BCPs

\begin{tabular}{|c|c|}
\hline Reference Principle & Recommended Action \\
\hline 1.2 Independence, accountability and transparency & $\begin{array}{l}\text { Amend the legal framework to require public } \\
\text { disclosure of the reasons the dismissal of the } \\
\text { Governor of the NBB. Adequacy of staff resources } \\
\text { needs to be reviewed. }\end{array}$ \\
\hline 4. Transfer of significant ownership & $\begin{array}{l}\text { Introduce a legal obligation for a credit institution to } \\
\text { notify the NBB of a material adverse development } \\
\text { that may negatively affect the suitability of a major } \\
\text { shareholder. }\end{array}$ \\
\hline 5. Major acquisitions & $\begin{array}{l}\text { Amend laws or regulations to ensure that the NBB } \\
\text { has the right of pre-approval of a major acquisition } \\
\text { by a credit institution in the nonfinancial sector. }\end{array}$ \\
\hline 7. Risk Management & $\begin{array}{l}\text { Continue to update the Circular on Internal } \\
\text { Governance with emphasis on role of the Board. } \\
\text { Develop a comprehensive risk management } \\
\text { standard, which articulates the NBB's minimum } \\
\text { expectations for risk management for banks and } \\
\text { groups (refer to international efforts). } \\
\text { In revising the Internal Governance Circular, require } \\
\text { the Internal Audit function to formally report to the } \\
\text { Audit Committee to ensure operational } \\
\text { independence. Also formalize current practice by } \\
\text { requiring major policies to be submitted to the NBB } \\
\text { when approved by the Board. } \\
\text { The baseline supervisory program (see CP20) should } \\
\text { include, e.g., meetings with the nonexecutive } \\
\text { directors (at least annually), review of Board minutes, } \\
\text { onsite review testing controls and risk management } \\
\text { and a meeting with the external auditor. The } \\
\text { supervision program should be linked to the risk } \\
\text { scorecard. } \\
\text { Establish a formal cycle for all accredited internal } \\
\text { models (Pillar 1) to be assessed on a regular basis. } \\
\text { The assessment should consider results of annual } \\
\text { tests, audit findings etc. }\end{array}$ \\
\hline 8. Credit Risk & $\begin{array}{l}\text { An effective delegation structure will strengthen the } \\
\text { risk management framework and help to avoid } \\
\text { unnecessary conflicts of interest which might arise } \\
\text { when granting credit, as the conflicts of interest } \\
\text { policy required by the regulations may prove } \\
\text { inadequate to mitigate this risk. }\end{array}$ \\
\hline 16. Interest rate risk in the banking book & $\begin{array}{l}\text { Write a single regulation to replace multiple rules } \\
\text { texts. Include requirements for stress testing and a } \\
\text { limit framework that reflects risk appetite. }\end{array}$ \\
\hline
\end{tabular}




\begin{tabular}{|l|l|}
\hline & $\begin{array}{l}\text { Require functional and operational separation of } \\
\text { markets and treasury function. }\end{array}$ \\
& $\begin{array}{l}\text { Consider requiring an Asset Liability Committee for } \\
\text { all credit institutions, to enhance the quality, } \\
\text { timeliness and management of this risk. }\end{array}$ \\
\hline 17. Internal control and audit & $\begin{array}{l}\text { Extend cross-sectoral analysis to a greater number of } \\
\text { banks. }\end{array}$ \\
\hline 20. Supervisory techniques & $\begin{array}{l}\text { Consider obtaining a positive assurance from the } \\
\text { external auditor as to the design and effectiveness of } \\
\text { controls. This report should extend beyond the } \\
\text { scope of the current engagement of the external } \\
\text { auditor, which is an assessment of the process and } \\
\text { documentation of the self assessment performed by } \\
\text { management. }\end{array}$ \\
\hline 21. Supervisory reporting & $\begin{array}{l}\text { Put in place a formal supervisory process to ensure } \\
\text { that each institution systematically receives the } \\
\text { appropriate intensity of supervisory attention } \\
\text { proportionate to its profile. }\end{array}$ \\
\hline $\begin{array}{l}\text { Align the reporting dates so that returns are } \\
\text { submitted at the same reporting date to enable } \\
\text { integrated and timely financial analysis. }\end{array}$ \\
\hline
\end{tabular}

\section{F. Authorities' Response to the Assessment}

30. The NBB can subscribe to the general conclusions and the main findings as laid down in this report. The NBB is satisfied with the overall high level of compliance with the 2006 Banking Core Principles and appreciates that recognition has been given to the challenging environment is which the NBB currently performs its supervisory tasks. The challenges stem from the continued crisis conditions and the relatively recent integration of prudential supervision into the NBB, formerly a task performed by the CBFA. During the mission, the NBB had the opportunity to explain the initiatives/reforms underway as a response to these challenges and to indicate how well advanced some of them already are. Discussions with the IMF were thus also a fruitful sounding board for the NBB and we will take into account the advice and recommendations to continue work in this respect.

31. For some of the Banking Core Principles, mainly those for which the NBB received a downgrade, we provide here some more extensive comments to the IMF's assessment or we indicate our future plans to meet the IMF's recommendations. 


\section{BCP 1: Objectives, independence, powers, transparency, and cooperation}

32. The NBB will reconsider the adequacy of the supervisory resources in order to achieve the appropriate supervisory intensity and effectiveness in the course of 2013.

\section{BCP 4: Transfer of significant ownership}

33. The obligation for a credit institution to inform the supervisory authority of any material adverse development (affecting the criteria under which the assessment of the suitability of a major shareholder is made) will be provided soon, on the occasion of the next Banking Law's modification.

\section{BCP 5: Major acquisitions}

34. The right of pre-approval by the NBB of a major acquisition by a credit institution in the nonfinancial sector will be provided soon, on the occasion of the next Banking Law's modification.

\section{BCP 6: Capital adequacy}

35. We agree with the conclusion relating to the deduction of insurance company but underline that the regulation will be adapted as from 1 January 2013 on.

36. With regard to the deduction of credits to shareholders that have been used to subscribe capital instruments, we underline that the current regulation is fully in line with the Basel 3 framework and notably the eligibility criterion 11 for common equity tier 1 which states that "the instrument is directly issued and paid-in and the bank can not directly or indirectly have funded the purchase of the instrument.

37. This last criterion is new with regard to the conditions that the instrument must be directly issued and the bank can not directly or indirectly have funded the purchase of the instrument. As these conditions are new, the NBB has introduced a transitional measure for the deduction of existing credits at the end of December 2010 in line with the transitional measures of the Basel 3 framework. In the meantime, existing credits that are not deducted from own funds are taken into consideration in the pillar 2 decision relating to capital add-ons set by NBB, meaning that the full amount of these credits must be covered by common equity tier 1 . All new credits that have been granted since end 2010 have been deducted from common equity tier 1 .

38. With regard to the transparency issue, we will follow the new European regulation transposing the Basel 3 framework that requires each bank to disclose the impact of any transitional measures to the market (see article 470 of the current draft CCR) from the entry into force of this regulation and the guidelines that EBA will issue with regard to disclosure on own funds (see EBA consultation paper EBA/CP2012/04 Consultation paper on draft implementing standards on disclosure for own funds).

39. In addition to the Basel criterion 11, the current Belgian regulation provides also for the deduction of credits to shareholders when they are not granted at market conditions and when 
there is no evidence that the shareholders have sufficient revenues on an ongoing basis, other than the distributions on the capital instruments held, to support the payment of interest and repayment of the funding.

40. In conclusion, we consider that the issue of credits to shareholders does not constitute a reason for a downgrade and that the NBB is compliant with principle 6 from 1 January 2013 on (when the insurance participations will be deducted from tier 1 and tier 2).

\section{BCP 7: Risk management}

41. The NBB plans to review its internal governance framework, including risk management, starting in the autumn of 2013. At that moment, we will take into account the IMF's recommendations regarding the Board's oversight role for risk management and on how to integrate risk management and capital setting better.

\section{BCP 8: Credit risk}

42. We largely agree with the assessment but it is unclear whether $B C P 8$ requires the regulation to prohibit some credit to shareholders because conflicts of interest may arise (and have arisen in the past). The management of conflicts of interest between the bank and the shareholders is already regulated by the provisions of company law and the guidelines of the NBB on internal governance. On the basis of these guidelines, each institution must define a policy relating to conflicts of interest which shall be subject to the scrutiny of the NBB. We agree that these legal provisions and guidelines are not necessary sufficient but NBB has clarified the own funds regulation in order to be able to deduct some transactions made between the bank and its shareholders from the own funds (see above for BCP 6).

\section{BCP 10: Large exposure limits}

43. The NBB will examine whether to use the national discretion to set a stricter limit on large exposures within smaller institutions when transposing Capital Requirements Directive, Fourth Iteration (CRD IV).

\section{BCP 12: Country and transfer risks}

44. We largely agree with the assessment but underline that the current guidelines of the NBB relating to credit risk management and concentration risk ensure already the compliance with the main principles applicable to the management of country risk (notably obligation to define a policy approved by the board, to set limits, to monitor the evolution of the exposures and the risks, to have an adequate provisioning policy and process). Adding specific guidance on country risk would be mainly a repetition of what is already included in the current guidelines on credit risk and concentration risk. 


\section{BCP 16: Interest rate risk in the banking book}

45. Interest rate risk has been recognized as one of the priorities in the NBB's Risk Review 2013. As explained to the IMF, the NBB has set up since 2012 an extensive program to further develop its supervision regarding interest rate risk that runs throughout its different supervision departments. When rolling out this program, the NBB will consider how the recommendations in this field can be translated into the NBB's practice.

\section{BCP 17: Internal control and audit}

46. It is unclear whether the actual $B C P 17$ requires that the supervisor should be satisfied as to the effectiveness of the internal controls. The June 2012 BCBS document requires the internal audit function to provide independent assurance on the quality and effectiveness of a bank's internal control.

47. If the supervisor should be satisfied as to the effectiveness of the internal controls, several options could be examined:

- The Bank could require the internal audit function to adhere to the IIA's International Professional Practices Framework (Practice Advisory 2130-1) and to the recently published principles of the BCBS document about the internal audit function in banks;

- The Bank could require the external auditors to give positive assurance on the design and effectiveness of the internal controls. As for internal controls over financial reporting, a reference could be made to PCAOB standard AS 5 (there is no equivalent in the IAASB suite of standards), for the other internal controls reference could be made to ISAE 3000. This standard is under revision and would require the Bank to describe in detail what is expected and what constitutes an acceptable internal control framework;

- It could be envisaged that positive assurance is obtained through on-site inspections performed by the Bank. This could be dealt with in the context of the NOVA project (aiming at a harmonization of and consistency in methods across the supervisory departments). It should however not be expected that such a positive assurance will be obtained on a yearly basis for all supervised institutions and regarding their complete internal control system.

48. We consider that obtaining, in a systematic and sufficiently documented way, comfort as to the design and effectiveness of internal controls is indeed necessary. The report by the external auditor is only one of the building blocks for the control by the NBB and its importance should therefore not be overestimated.

49. To summarize, in our opinion, comfort should be obtained through a pre-defined combination of senior management's self-assessment (as approved by the Board), ICAAP reporting, input from the internal auditors (cf. recent BCBS document about the internal audit function in banks) and from the external auditor, as well as NBB on-site inspections to test these different inputs. This combination is currently the case. We agree however that the process for integrating 
these different building blocks and for steering the interaction between them could be made somewhat stricter. We will also enhance our own quality assurance on the input of the external auditor. The NBB will include this work when designing baseline supervision (see also BCP 20).

\section{BCP 20: Supervisory techniques}

50. We overall agree with the assessment but like to offer some additional inputs to the points contained in the detailed assessment:

- Supervisory action and planning is generally based on priorities and oriented to high risk institutions. We confirm the need to better document choices and to present supervisory planning and realized actions on the basis of a formally agreed and sector wide methodology;

- Pressure is put on team members to strengthen the internal documentation process, to systematically introduce standard presentation, including comparison to peers, in order to make risk assessment more comprehensive and ensure level playing field;

- The ongoing development of a enhanced scorecard system will strengthen the structured dialogue both with the institutions concerned and with their approved commissioners and the competent supervisory authorities, notably via the colleges of supervisors, will drive the decision making process, and will be systematically used and included in periodic reporting to the Board;

- This enhanced scorecarding will facilitate clustering on a more refined and risk-focused basis and will lead to a more balanced and risk based supervisory planning and subsequent appropriate assignment of staff.

51. At the time of closing the FSAP mission, the NBB has already started work to implement a baseline supervision approach. We are in the process of identifying the different clusters and as result of this process, we have to define a baseline supervision even for the low risk institutions.

\section{BCP 21: Supervisory reporting}

52. The European Implementing Technical Standards (ITSs) on reporting, currently prepared by the EBA in the context of the future CRD IV, will shorten the remittance dates for prudential returns. These standards will become directly applicable in Belgium. 


\section{INTERNATIONAL ASSOCIATION OF INSURANCE SUPERVISORS (IAIS) INSURANCE CORE PRINCIPLES}

\section{A. Background}

53. This assessment provides an update on the significant regulatory and supervisory developments in the insurance sector of Belgium since 2006. It is benchmarked against the ICPS issued by the IAIS in October 2011. The assessment is based solely on the laws, regulations and other supervisory requirements and practices that are in place at the time of the assessment.

54. The supervisory architecture in Belgium has been overhauled with the implementation of the Twin Peaks structure in April 2011. The NBB is in charge of the micro- and macroprudential supervision of insurers, while the FSMA is responsible for registering the intermediaries and for supervising the conduct of business by insurers and intermediaries. This assessment covers the both the NBB and FSMA.

55. The Belgian insurance industry is mature and concentrated. It is relatively small compared to the banking sector: assets held by banks are five times of those held by insurers as at September 2011. Although there are 92 direct insurers, the industry is dominated by the 23 composite insurers that conduct both life and nonlife insurance operations, accounting for more than 90 percent of total industry assets. In 2011, the top five life insurers accounted for 71 percent of the assets while the top five nonlife insurers held 58 percent of the assets. The top three insurance groups held more than 60 percent of the total assets as at end-2011.

56. Belgian insurers were adversely affected by the global financial crisis and continue to confront challenges related to legacy portfolios and economic uncertainties in Europe.

Government support was extended to a few insurers to maintain the stability of the industry in 2008. Nevertheless, the insurance industry's solvency position has continued to weaken since 2009, and life insurers have significant exposures to guaranteed high returns in part of their legacy portfolios. Insurers held high levels of government bonds ( $€ 104$ billion), accounting for 41 percent of assets as at end-2011, of which $€ 59.6$ billion were in Belgian government bonds. Investments in corporate bonds represent 23 percent of total assets. While insurers have been gradually shifting toward contracts that offer lower guarantees, some of the new contracts offer more policy options, increasing the risks of surrenders by policyholders. The demand for life policies has been eroded by households' stronger preference for liquidity. Nonlife insurers have taken measures to improve their underwriting performance but they remain susceptible to investment risks.

\section{B. Preconditions for Effective Securities Regulation}

57. The preconditions for effective insurance supervision are in place in Belgium. The macroeconomic, fiscal and legal frameworks of Belgium are partly shaped by its membership in the European Union (EU). The legal system in Belgium is developed and the independence of the judiciary is respected. Accounting, auditing and actuarial standards adopted are in line with 
international best practices. The NBB publishes comprehensive macroeconomic statistics on its website. The regulated stock exchange (Euronext) is subject to investor protection and governance rules, information disclosure requirements and supervision by the FSMA. Belgium's corporate governance system is in line with the Organization for Economic Cooperation and Development's Principles of Corporate Governance. The legal framework for consumer protection is well established and policyholders of traditional life policies (except for group insurance related to employee benefits) are covered by the Deposit Guarantee Scheme up to $€ 100,000$ per policyholder since 2008. The financial markets in Belgium offer a broad range of instruments that facilitate insurers' assetliability management.

\section{Main Findings}

58. The Belgian authorities have made significant progress in updating the insurance regulatory regime and supervisory practice since 2006 . The authorities have implemented the Flashing Light Provisions to strengthen the solvency requirements of life insurers with exposures to legacy portfolios and enhanced the risk management requirements for insurers. The NBB has introduced a supervisory framework that integrates vertical analyses of individual insurers with horizontal review of the insurance sector, while leveraging on its macroeconomic competencies. Checks-and-balances in the supervisory process have been enhanced through the separation of vertical and horizontal supervision as well as offsite review and onsite inspections.

59. There is scope for strengthening the supervisory structure and the legal capacity of the NBB. The Twin Peaks structure establishes clear supervisory mandates and enhances checksand-balances. A key success factor is effective communication and coordination. A regular review of the practical implementation of the Twin Peaks is needed to ensure that the overall supervisory objectives for the insurance sector are effectively achieved. A more principles-based approach in delegating legal authority to the NBB to issue enforceable rules would facilitate supervisory discretion within the parameters set by the law. The NBB should be empowered to take immediate recovery measures not withstanding an appeal by an insurer. There are merits in articulating clear policies to deal with potential conflicts in supervisory objectives, e.g., between financial stability and prudential safeguards for policyholders.

60. The updated regulatory framework has a high level of observance with the ICPs, supported by robust prudential supervision. The majority of the downgrades reflect gaps in the regulatory framework, i.e.; scope of the fit and proper requirements; duties of directors particularly with respect to policyholders; public disclosures; updating the prudential standards for asset-liability management and realistic contingency plans. The NBB's decision to enhance the current solvency regime ahead of the implementation of Solvency II is welcome, and should contribute to the longer-term sustainability of insurers. Further improvements could be achieved through: a) the formulation of an appropriate baseline supervisory program; b) internal policies for inspecting functions outsourced by insurers; and c) review of the effectiveness of contributions of external auditors and the role of actuaries. 


\section{The authorities are advised to review current conduct-of-business (COB) regulation} and supervision. Although training and qualification requirements imposed by the FSMA complies with the EU IMD directive, there is scope to enhance the level of professionalism of intermediaries through more robust training requirements and appropriate supervisory measures to deter unhealthy competition arising from more than 17,000 intermediaries. The FSMA proposes to adapt the Markets in Financial Instruments Directive 2 (MiFID 2) to insurers and insurance intermediaries, aimed at providing a cross-sectoral and comprehensive framework for COB regulation. The FSMA should be empowered to establish enforceable rules on: a) handling of claims and proper policy servicing by insurers; b) market conduct requirements at the group level; and c) combating and reporting insurance fraud by intermediaries.

\section{It will be important that the NBB and the FSMA are adequately resourced to} effectively discharge their supervisory mandates. The NBB is advised to regularly review its resource planning to achieve the appropriate supervisory intensity and effectiveness and an appropriate baseline program. Going forward, there are also significant resource implications arising from the implementation of Solvency II and supervision of complex cross-border insurance groups/conglomerates. The FSMA needs to strategize an appropriate risk-based supervisory approach to deal with the large population of regulated entities and ensure adequate resources to implement the strategy.

63. Table 3 offers a principle-by-principle summary of the assessment results, while recommendations to improve observance of the ICPs are summarized in Table 4.

Table 3: Summary of Compliance with the ICPs

\begin{tabular}{|l|l|}
\hline \multicolumn{1}{|c|}{$\begin{array}{c}\text { Insurance Core } \\
\text { Principle }\end{array}$} & \multicolumn{1}{c|}{ Overall comments } \\
\hline $\begin{array}{l}\text { 1. Objectives, Powers } \\
\text { and Responsibilities } \\
\text { of the Supervisor }\end{array}$ & $\begin{array}{l}\text { The NBB and the FSMA have clear supervisory mandates under the Twin Peaks } \\
\text { structure, which also enhances checks-and-balances. The objectives of the } \\
\text { supervision of insurers and reinsurer are defined in the primary legislations. The } \\
\text { NBB may establish enforceable rules within the parameters specifically } \\
\text { prescribed in the primary law, subject to the approval of the King or a Minister. }\end{array}$ \\
\hline 2. Supervisor & $\begin{array}{l}\text { The NBB and the FSMA have financial independence and they are subject to } \\
\text { clear accountability mechanisms. Both the supervisors and their staff members } \\
\text { are legally obliged to safeguard confidential information and have the } \\
\text { necessary legal protection against civil liability except for fraud or gross } \\
\text { negligence. } \\
\text { While the NBB and the FSMA have budgetary discretion, there is a need to } \\
\text { strengthen their supervisory resources to achieve appropriate supervisory } \\
\text { intensity and effectiveness. There are explicit procedures for the appointment } \\
\text { and dismissal of the members of the governing bodies of the NBB and the } \\
\text { FSMA, There is an established policy on the composition of the NBB Board in } \\
\text { terms of diversity of experience and skill set. The lack of internal policy and } \\
\text { procedure to ensure prompt escalation of significant events and the lack of } \\
\text { authority for the NBB to take recovery measures as immediately executable } \\
\text { may hinder timely intervention. There is scope for strengthening the resources }\end{array}$ \\
\hline
\end{tabular}




\begin{tabular}{|c|c|}
\hline & $\begin{array}{l}\text { of the Internal Audit Service to provide quality assurance on the integrity of } \\
\text { supervisory activities of the NBB. }\end{array}$ \\
\hline $\begin{array}{l}\text { 3. Information } \\
\text { Exchange and } \\
\text { Confidentiality } \\
\text { Requirements }\end{array}$ & $\begin{array}{l}\text { The NBB is empowered to obtain and exchange information with relevant } \\
\text { supervisors and authorities subject to confidentiality, purpose and use } \\
\text { requirements. The existence of an agreement or understanding on information } \\
\text { exchange is, generally, not a prerequisite for information exchange. The NBB } \\
\text { may share information with non-EEA supervisors on a reciprocal basis or } \\
\text { pursuant to cooperation agreements. } \\
\text { Internationally, the NBB is signatory to the IAIS Multilateral MOU. The NBB also } \\
\text { participates actively in relevant supervisory colleges, where information } \\
\text { exchanges are to be facilitated by coordination arrangements. However, the } \\
\text { coordination arrangements are not yet signed officially, pending the } \\
\text { implementation of Solvency II. } \\
\text { Domestically, the MOU between the NBB and the FSMA was under discussion } \\
\text { at the time of assessment. There is also scope for the FSMA and the NBB to } \\
\text { review how best to strengthen supervisory cooperation as they gain experience } \\
\text { in implementing the twin-peaks structure. }\end{array}$ \\
\hline 4. Licensing & $\begin{array}{l}\text { Insurance activities within Belgium can only be conducted by authorized } \\
\text { insurers/ reinsurers. The NBB is the licensing authority and the requirements } \\
\text { and procedures for obtaining authorization are clearly defined, objective and } \\
\text { public. A multidisciplinary team evaluates applications for authorization in } \\
\text { accordance with established internal procedures, taking account of the FSMA's } \\
\text { opinion. } \\
\text { A draft Royal Decree has been prepared to provide partial exemptions to } \\
\text { mutual insurance associations and cooperative societies that limit their } \\
\text { activities to the municipality where their registered office is located, or to that } \\
\text { municipality and neighboring municipalities. The NBB has not taken action } \\
\text { against the noncompliance with the authorization requirement by certain } \\
\text { mutual insurance associations and cooperative societies on the basis of that } \\
\text { their operations are limited in scale; and these institutions would not fall within } \\
\text { the scope of the draft Royal Decree nor the future Solvency II rules. }\end{array}$ \\
\hline 5. Suitability of Persons & $\begin{array}{l}\text { The NBB assesses the fitness and propriety of Board Members and Senior } \\
\text { Management at the stage of proposed appointment and re-appointment, } \\
\text { based on comprehensive information and extensive deliberation. It is in the } \\
\text { process of revising its fit and proper regulation and the key enhancements } \\
\text { include: extending the suitability requirements to Key Persons in Control } \\
\text { Functions; requiring notifications by insurers of circumstances that may } \\
\text { materially adversely affect the suitability of persons and greater clarity on the } \\
\text { criteria for fitness and propriety. }\end{array}$ \\
\hline $\begin{array}{l}\text { 6. Changes in Control } \\
\text { and Portfolio Transfers }\end{array}$ & $\begin{array}{l}\text { The Insurance Law defines qualifying holdings and set the thresholds for the } \\
\text { acquisition of and increase/decrease in qualifying holdings, which require the } \\
\text { prior approval of the NBB. The criteria for assessing acquisition proposals are } \\
\text { the same as those applicable for initial authorization applications. Insurers are } \\
\text { required to: a) notify the NBB of changes in qualifying holdings that would } \\
\text { result in a person's holdings either to exceed or to fall below the specified } \\
\text { thresholds; and b) submit the names of their Significant Owners annually. } \\
\text { Portfolio transfers are subject to the approval of the NBB. }\end{array}$ \\
\hline
\end{tabular}




\begin{tabular}{|c|c|}
\hline & $\begin{array}{l}\text { The NBB and the FSMA do not have the power to approve or oppose the } \\
\text { conversion of a mutual company to a stock company. Nonetheless, they are } \\
\text { expected to comment on the conversion proposal and may intervene through } \\
\text { indirect means, if necessary. Such conversion has been rare in Belgium. }\end{array}$ \\
\hline $\begin{array}{l}\text { 6. Corporate } \\
\text { Governance }\end{array}$ & $\begin{array}{l}\text { Since 2006, the authorities have significantly strengthened the regulation and } \\
\text { supervision of insurers' corporate governance, by adopting legally binding } \\
\text { minimum requirements, supplemented by a comply-or-explain approach that is } \\
\text { supported by detailed supervisory guidance. The NBB's assessment of insurers' } \\
\text { governance practices is a key input in the Scorecard System and in prioritizing } \\
\text { it risk-based supervision. The authorities are in the process of updating the } \\
\text { Internal Governance Circular to take account of evolving international best } \\
\text { practices. }\end{array}$ \\
\hline $\begin{array}{l}\text { 8. Risk Management } \\
\text { and Internal Controls }\end{array}$ & $\begin{array}{l}\text { The authorities have established sophisticated principles-based risk } \\
\text { management and internal control system requirements. Stronger requirements } \\
\text { apply to insurers who are exempted from the Flashing Light provisions. The } \\
\text { external auditors play a substantial role in reviewing insurers' reports to the } \\
\text { NBB on their internal control system (refer to ICP 9). }\end{array}$ \\
\hline $\begin{array}{l}\text { 9. Supervisory Review } \\
\text { and Reporting }\end{array}$ & $\begin{array}{l}\text { The NBB has introduced an integrated risk assessment framework that is } \\
\text { supported by a risk-based supervisory process. The supervisory framework } \\
\text { integrates vertical analyses of individual insurers with horizontal review of the } \\
\text { insurance sector, while leveraging on its macroeconomic competencies. } \\
\text { Checks-and-balances in supervisory assessment have been enhanced through } \\
\text { the separation of vertical and horizontal supervision as well as the off-site } \\
\text { review and on-site inspections. The NBB has also established policies and } \\
\text { procedures with respect to the contributions of the accredited auditors' } \\
\text { contribution to the supervisory process. } \\
\text { The Scorecard system facilitates proper documentation and consistency of } \\
\text { supervisory assessments as well as providing a structured framework to discuss } \\
\text { supervisory issues. The intensity of supervisory engagement is prioritized based } \\
\text { on a risk-based approach. The NBB is empowered to collect extensive } \\
\text { regulatory and statistical information from insurers and the reporting } \\
\text { obligation applies at both the solo and group levels. Since January 2012, the } \\
\text { NBB has been conducting on-site inspection based on audit techniques, with } \\
\text { clear scoping and formalized work program. It issues formal reports on its } \\
\text { findings and remedial measures and monitors the implementation of required } \\
\text { measures. NBB may inspect service providers of outsourced functions but has } \\
\text { not conducted such inspections. } \\
\text { Early implementation of certain elements of Solvency II would improve the } \\
\text { coverage and quality of regulatory reporting. It is also critical that the NBB } \\
\text { carefully plan for adequate resources to conduct effective supervision. } \\
\text { Given its broad mandate in supervising a large number of licensees, FSMA } \\
\text { typically monitors insurers' compliance with COB requirements based on off- } \\
\text { site reviews. On-site visits of insurers are typically driven by external triggers } \\
\text { while the inspections of intermediaries focus mainly on compliance with } \\
\text { registration requirements. }\end{array}$ \\
\hline $\begin{array}{l}\text { 10. Preventive and } \\
\text { Corrective Measures }\end{array}$ & $\begin{array}{l}\text { Unauthorized insurance activities constitute an offence under the Insurance } \\
\text { Law and the NBB and FSMA may refer such cases for prosecution. The NBB has } \\
\text { a range of preventive and corrective measures that supports the progressive }\end{array}$ \\
\hline
\end{tabular}




\begin{tabular}{|c|c|}
\hline & $\begin{array}{l}\text { escalation of actions. Before taking such measures, the NBB exercises moral } \\
\text { suasion and works with the insurers concerned to rectify any deficiencies within } \\
\text { a specified timeframe. }\end{array}$ \\
\hline 11. Enforcement & $\begin{array}{l}\text { The NBB and the FSMA have a wide range of powers to take enforcement } \\
\text { action and impose sanctions. A transparent process and the engagement of the } \\
\text { Sanctions Committees (to be established) in the NBB and of the Sanctions } \\
\text { Committee of the FSMA helps to ensure proportionate and consistent sanction } \\
\text { decisions. }\end{array}$ \\
\hline $\begin{array}{l}\text { 12. Winding-up and } \\
\text { Exit from the Market }\end{array}$ & $\begin{array}{l}\text { The winding-up of insurers is based on the procedure set out in the Insolvency } \\
\text { Law (insolvency) and the Company Code (dissolution and liquidation), subject } \\
\text { to certain modifications set out in the Insurance Law. Policyholders have } \\
\text { priority of claim above other unsecured creditors in the event of a winding-up. } \\
\text { The Insurance Law that determines the point at which it is no longer } \\
\text { permissible for an insurer to continue its business. }\end{array}$ \\
\hline $\begin{array}{l}\text { 13. Reinsurance and } \\
\text { Other Forms of Risk } \\
\text { Transfer }\end{array}$ & $\begin{array}{l}\text { The NBB requires insurers to submit comprehensive information on their } \\
\text { reinsurance programs and its IT Tool calculates standard early warning } \\
\text { indicators automatically. Reinsurance is taken into account in the PCR (solvency } \\
\text { margin) using rough proxies and the risk mitigating effect might be under- or } \\
\text { overstated for some forms of reinsurance (e.g., for nonproportional covers). } \\
\text { This has to be balanced with the resources required to perform a more detailed } \\
\text { analysis, particularly for complex reinsurance programs. Reinsurance credit risks } \\
\text { are not considered adequately. Similarly, concentration risk arising from } \\
\text { reinsurance ceded to only one or few reinsurers is not considered. }\end{array}$ \\
\hline 14. Valuation & $\begin{array}{l}\text { The valuation of assets and liabilities for solvency purposes must conform to } \\
\text { applicable accounting standards at both solo (BGAAP) and group level (IFRS). } \\
\text { The valuation approach for assets covering TP is generally market-based, } \\
\text { except for sovereign bonds, which are valued at amortized cost less } \\
\text { depreciation/impairment. TP are valued at historical cost. } \\
\text { Arising from the supervisors' observation that some insurers have not applied } \\
\text { the valuation approach (notably on impairments) with the expected rigor, the } \\
\text { NBB has reviewed insurers' valuation of certain assets in more depth since the } \\
\text { financial crisis and has taken action against insurers. } \\
\text { The NBB focuses mainly on the level of TP and less on the methods used to } \\
\text { calculate TP. The current valuation standard for TP is based on implicit } \\
\text { prudence without an explicit current estimate and Margin over Current } \\
\text { Estimate (MOCE). This makes the analysis of the sufficiency of TP more difficult } \\
\text { for the NBB. }\end{array}$ \\
\hline 15. Investment & $\begin{array}{l}\text { The regulatory requirements apply only the assets covering insurers' TP i.e., } \\
\text { there are no requirements on free assets. ALM requirements for some insurers } \\
\text { have been implemented since } 2006 \text { in relation to the Flashing Light provision } \\
\text { and there is scope for updating the prudential standard to reflect evolving best } \\
\text { practices. In addition, insurers have to formulate crisis scenarios and quantify } \\
\text { the impact as part of their ALM framework. Effective supervision of insurers' } \\
\text { ALM hinges on adequate technical supervisory capacity. }\end{array}$ \\
\hline $\begin{array}{l}\text { 16. Enterprise Risk } \\
\text { Management for } \\
\text { Solvency Purposes }\end{array}$ & $\begin{array}{l}\text { The current prudential standards have established some elements of the } \\
\text { regulatory requirements for an enterprise risk management by insurers. To } \\
\text { meet ICP 16, there should be clearer requirements and more comprehensive } \\
\text { scope on insurers' risk management policy, particularly for investment and } \\
\text { underwriting risks. In addition, enterprise risk management should be }\end{array}$ \\
\hline
\end{tabular}




\begin{tabular}{|c|c|}
\hline & $\begin{array}{l}\text { supported by an ORSA. Currently, some elements of ORSA are applicable only } \\
\text { to those insurers that are exempted from the Flashing Light provision. }\end{array}$ \\
\hline 17. Capital Adequacy & $\begin{array}{l}\text { The current Solvency I framework is not risk-based-the capital requirement } \\
\text { does not take all material risk into account, e.g., credit risk, and if risks are } \\
\text { taken into account, this is not done explicitly. The capital requirement is also } \\
\text { not consistent with the valuation standard. Capital adequacy does not explicitly } \\
\text { consider the following factors on a realistic basis: asset liability matching; } \\
\text { reinsurance and other risk mitigating measures; or diversification between risks. } \\
\text { Group capital requirements are also based on Solvency I, which does not take } \\
\text { into account group-specific risks e.g., contagion risks. } \\
\text { While there are two solvency control levels, the MCR is not a minimum bound } \\
\text { below which no insurer is regarded to be viable to operate effectively, i.e., there } \\
\text { is no solvency control level which leads to an automatic strongest supervisory } \\
\text { actions in the absence of appropriate corrective action by an insurer. }\end{array}$ \\
\hline 18. Intermediaries & $\begin{array}{l}\text { Although the registration conditions for intermediaries are clear and } \\
\text { transparent and the training and qualification requirements imposed by the } \\
\text { FSMA comply with the EU IMD directive, there is scope to raise the continuous } \\
\text { professional development requirements. The FSMA's supervision of } \\
\text { intermediaries focuses mainly on checking compliance with registrations } \\
\text { requirements. While the pre-contract information disclosure provides adequate } \\
\text { information on an intermediary's status and relationship with insurers, } \\
\text { disclosure on potential conflict of interest could be enhanced, particularly } \\
\text { relating to remuneration arrangements. The FSMA conducts on-site inspections } \\
\text { of intermediaries and has withdrawn or suspended the registrations of } \\
\text { intermediaries who failed to meet its requirements. The legal framework } \\
\text { provides protection for clients monies handled through intermediaries. }\end{array}$ \\
\hline $\begin{array}{l}\text { 19. Conduct of } \\
\text { Business }\end{array}$ & $\begin{array}{l}\text { The current COB regime focuses on prohibition against unfair and misleading } \\
\text { practices. The implementation of the voluntary moratorium of structured } \\
\text { products that are considered as "particularly complex" in August } 2011 \text { is a } \\
\text { commendable supervisory initiative. The emerging international best practices } \\
\text { are to promote fair treatment of customers that are an integral part of business } \\
\text { culture of insurers and intermediaries. In this regard, the FSMA has proposed } \\
\text { amendments to the Supervision Law to impose a general obligation on insurers } \\
\text { and insurance intermediaries to act fairly, honestly and professionally in the } \\
\text { best interests of their clients and provide correct, clear and not misleading } \\
\text { information. The proposed adaptation of MiFID } 2 \text { to insurance meditation will } \\
\text { enhance COB requirements. }\end{array}$ \\
\hline 20. Public Disclosure & $\begin{array}{l}\text { The current disclosure regime in Belgium focuses on the financial position and } \\
\text { performance of insurers and there are significant gaps in the disclosures on: } \\
\text { technical provisions, risk management and exposures, details of performance } \\
\text { and capital adequacy. The application of IFRS as from financial year } 2012 \text { has } \\
\text { improved the disclosures made in consolidated accounts. The impending } \\
\text { implementation of Solvency II will bring the disclosure regime in line with } \\
\text { international best practices. }\end{array}$ \\
\hline $\begin{array}{l}\text { 21. Countering Fraud } \\
\text { in Insurance }\end{array}$ & $\begin{array}{l}\text { While there is no specific legislation on insurance fraud, the general criminal } \\
\text { law adequately addresses fraudulent conduct relating to insurance, which are } \\
\text { subject to criminal proceedings. Supervisory attention for fraud is part of the } \\
\text { assessments relating to governance/risk management, compliance and internal } \\
\text { audit functions (where applicable) of insurers. The insurance industry has taken }\end{array}$ \\
\hline
\end{tabular}




\begin{tabular}{|c|c|}
\hline & $\begin{array}{l}\text { measures to counter fraud such as training programs, sharing information via } \\
\text { databases and a new code of conduct concerning insurance fraud prevention. } \\
\text { The NBB and FSMA may cooperate, coordinate and exchange information } \\
\text { relating to insurance frauds with other competent authorities, including foreign } \\
\text { authorities. }\end{array}$ \\
\hline $\begin{array}{l}\text { 22. Anti-Money } \\
\text { Laundering and } \\
\text { Combating the } \\
\text { Financing of Terrorism }\end{array}$ & $\begin{array}{l}\text { The NBB and FSMA are aware of the money laundering and terrorism financing } \\
\text { risks of the insurance industry and have effective mechanisms to cooperate, } \\
\text { coordinate and exchange information with both domestic and foreign } \\
\text { supervisors/FIUs. The authorities are reviewing the current AML-CFT regime to } \\
\text { take account of the new FATF Recommendations of February } 2012 \text {. }\end{array}$ \\
\hline $\begin{array}{l}\text { 23. Group-wide } \\
\text { Supervision }\end{array}$ & $\begin{array}{l}\text { The supplementary supervision of insurance groups in Belgium is shaped by EU } \\
\text { Directive and facilitated by a structured coordination framework organized by } \\
\text { EIOPA. The NBB has adequate powers and flexibility to determine the scope of } \\
\text { insurance groups as well as to supervise and take appropriate measures against } \\
\text { both regulated and nonregulated entities within a group. The NBB is actively } \\
\text { involved in supervisory colleges, both as a home and host supervisor (ICP 25). } \\
\text { However, there are no group-wide market conduct requirements. There is also } \\
\text { scope for establishing consistent supervisory processes for group supervision } \\
\text { e.g., in reporting intragroup transactions. Although the NBB has concluded } \\
\text { supervisory cooperation agreements with other insurance supervisors, there is } \\
\text { scope for improvement. }\end{array}$ \\
\hline $\begin{array}{l}\text { 24. Macroprudential } \\
\text { Surveillance and } \\
\text { Insurance Supervision }\end{array}$ & $\begin{array}{l}\text { As the central bank and prudential supervisor, the NBB is well placed in } \\
\text { achieving effective macroprudential surveillance. It collects extensive } \\
\text { quantitative and qualitative information quarterly, complemented by ad-hoc } \\
\text { questionnaires, if necessary. Its Macrofinancial Committee serves as a forum for } \\
\text { the exchange of information on macro-financial developments in Belgium and } \\
\text { in countries where Belgian institutions have exposure. The Risk Committee } \\
\text { oversees cross-sectoral risk analyses by risks areas to facilitate early detection } \\
\text { of potential systemic threats/ risks. The NBB participates in the EIOPA stress } \\
\text { testing exercises and conducts its own stress tests of the Belgian insurance } \\
\text { sector. }\end{array}$ \\
\hline $\begin{array}{l}\text { 25. Supervisory } \\
\text { Cooperation and } \\
\text { Coordination }\end{array}$ & $\begin{array}{l}\text { The NBB has established comprehensive coordination arrangements with other } \\
\text { involved supervisors to facilitate effective supervision on a legal-entity and a } \\
\text { group-wide basis. The NBB chairs three supervisory colleges as the group-wide } \\
\text { supervisor. Where appropriate, the NBB coordinates with relevant agencies } \\
\text { from other sectors, including central banks and government ministries. Pending } \\
\text { the implementation of Solvency II, the coordination arrangements have not } \\
\text { been concluded for all insurance groups although all the colleges have been } \\
\text { operating in line with the EIOPA's templates. The NBB became a signatory to } \\
\text { the IAIS Multilateral MOU in December } 2011 \text {. }\end{array}$ \\
\hline $\begin{array}{l}\text { 26. Cross-border } \\
\text { Cooperation and } \\
\text { Coordination on Crisis } \\
\text { Management }\end{array}$ & $\begin{array}{l}\text { The Belgian regime for cross-border cooperation and coordination on crisis } \\
\text { management is based on the EU framework, which has been partially } \\
\text { operationalized. The EU Framework supports and provides guidance on } \\
\text { coordinating the arrangements for crisis preparation, management and } \\
\text { resolution by supervisory colleges in EU. However, coordination arrangements } \\
\text { and emergency plans have not yet been implemented for all supervisory } \\
\text { colleges that the NBB participates in. Some insurance groups are still in the } \\
\text { process of developing their contingency plans. }\end{array}$ \\
\hline
\end{tabular}


Table 4. Recommendations to Improve Observance of ICPs

\begin{tabular}{|c|c|}
\hline $\begin{array}{l}\text { Insurance Core } \\
\text { Principle }\end{array}$ & \\
\hline $\begin{array}{l}\text { 1. Objectives, Powers } \\
\text { and Responsibilities of } \\
\text { the Supervisor }\end{array}$ & $\begin{array}{l}\text { Conduct regular reviews of the practical implementation of the Twin Peaks } \\
\text { structure, to identify and assess any potential gaps, duplication or coordination } \\
\text { issues. } \\
\text { Consider a more principle-based approach in delegating legal authority to the } \\
\text { NBB to issue enforceable rules. }\end{array}$ \\
\hline 2. Supervisor & $\begin{array}{l}\text { Empower the NBB to declare its decisions to take recovery measures with } \\
\text { respect to insurers as immediately executable, notwithstanding an appeal; } \\
\text { Ensure that the NBB and FSMA have adequate supervisory resources to achieve } \\
\text { the appropriate supervisory intensity and effectiveness, including a baseline } \\
\text { supervisory program; } \\
\text { Consider clarifying that the scope and circumstances for Minister's supervision of } \\
\text { the NBB's "transactions" does not cover the its supervisory activities; } \\
\text { Establish clear policies, procedures and decision making lines to ensure prompt } \\
\text { escalation of significant issues to appropriate levels within the NBB as well as in } \\
\text { cases of emergency; and } \\
\text { Review the adequacy of resources of the Internal Audit Service of the NBB. }\end{array}$ \\
\hline $\begin{array}{l}\text { 3. Information } \\
\text { Exchange and } \\
\text { Confidentiality } \\
\text { Requirements }\end{array}$ & $\begin{array}{l}\text { Expedite the conclusion of the MOU between the NBB and the FSMA to guide } \\
\text { effective cooperation and exchange of information. }{ }^{1}\end{array}$ \\
\hline 4. Licensing & $\begin{array}{l}\text { Expedite the finalisation of the draft Royal Decree establishing proportionate } \\
\text { regulatory requirements for local mutual insurance associations and cooperative } \\
\text { societies. }\end{array}$ \\
\hline 5. Suitability of Persons & Expedite the revision of the fit and proper regulation. \\
\hline $\begin{array}{l}\text { 6. Changes in Control } \\
\text { and Portfolio Transfers }\end{array}$ & $\begin{array}{l}\text { Consider empowering the NBB and FSMA to approve the conversion of the } \\
\text { mutual companies to stock companies. }\end{array}$ \\
\hline $\begin{array}{l}\text { 7. Corporate } \\
\text { Governance }\end{array}$ & $\begin{array}{l}\text { Establish clearer and explicit supervisory expectation on: } \\
\text { a) the duties for directors to act in a manner that would not compromise the } \\
\text { interests of an insurer and policyholders, particularly in a group context; and } \\
\text { b) adequate powers and resources for the Board of directors to exercise } \\
\text { effective oversight. }\end{array}$ \\
\hline $\begin{array}{l}\text { 9. Supervisory Review } \\
\text { and Reporting }\end{array}$ & $\begin{array}{l}\text { Strengthen the effectiveness of on-going supervision by: } \\
\text { a) Developing an appropriate baseline supervisory program; } \\
\text { b) Strategizing an appropriate risk-based COB supervision by the FSMA; } \\
\text { c) Reviewing the scope and effectiveness of leveraging on the work of external } \\
\text { auditors and actuaries in the supervisory process; } \\
\text { d) Establishing internal policies for inspecting outsourced functions by the NBB }\end{array}$ \\
\hline
\end{tabular}

${ }^{1}$ Following the FSAP mission, a general MOU on collaboration between the NBB and the FSMA to ensure coordination of the supervision of institutions under the respective supervision of the two agencies has been concluded on March 14, 2013. 


\begin{tabular}{|c|c|}
\hline & $\begin{array}{l}\text { and FSMA; and } \\
\text { e) Ensuring that both the FSMA and the NBB are equipped with adequate } \\
\text { supervisory resources including the technical capacity to achieve the } \\
\text { appropriate coverage and supervisory intensity. }\end{array}$ \\
\hline $\begin{array}{l}\text { 13. Reinsurance and } \\
\text { Other Forms of Risk } \\
\text { Transfer }\end{array}$ & $\begin{array}{l}\text { Strengthen the prudential standards relating to reinsurance, and require insurers } \\
\text { to embed the management of reinsurance risk as part of their risk management } \\
\text { framework, particularly with respect to counterparty, concentration and liquidity } \\
\text { risks arising from reinsurance. } \\
\text { Formulate appropriate standards applicable for risk transfer to capital markets. }\end{array}$ \\
\hline 14. Valuation & $\begin{array}{l}\text { Enhance NBB's supervisory assessment to include explicit consideration of the } \\
\text { underlying assumptions and methods used to estimate the TP. } \\
\text { Build technical capacity to conduct supervisory reviews and consider how best to } \\
\text { leverage on the actuarial functions of insurers. } \\
\text { Monitor the cost of insurance liabilities, in particular for life insurers' legacy } \\
\text { portfolios with high guarantees. } \\
\text { Strengthen the Flashing Light approach and put in place a sound market } \\
\text { consistent valuation standard for TP, either as a Pillar } 1 \text { or as a Pillar } 2 \\
\text { requirement for all insurers. } \\
\text { Consider introducing a sound market consistent valuation approach as part of its } \\
\text { decision to implement Solvency II ahead of the official timeline. The current } \\
\text { Flashing Light provision might be a basis for extending an appropriate market- } \\
\text { consistent valuation (MCV) standard to all insurers. }\end{array}$ \\
\hline 15. Investment & $\begin{array}{l}\text { The implementation of Solvency II will establish clearer supervisory expectations } \\
\text { on insurers' own risk and solvency assessment. The NBB intends to enhance its } \\
\text { supervisory competences on ALM through advanced training and development } \\
\text { initiatives. } \\
\text { The mission supports the NBB's proposal to update the prudential standards for } \\
\text { ALM to reflect evolving international best practices and strengthening } \\
\text { supervisory capacity to assess insurers' ALM practices. It is also advisable to } \\
\text { establish formal regulatory requirements on the investments of insurance } \\
\text { groups. }\end{array}$ \\
\hline $\begin{array}{l}\text { 16. Enterprise Risk } \\
\text { Management for } \\
\text { Solvency Purposes }\end{array}$ & $\begin{array}{l}\text { The NBB's decision to implement ORSA earlier than the official Solvency II } \\
\text { timeline will improve observance of ICP } 16 \text {. For ORSA to be truly effective, it } \\
\text { needs to be supported by a sound valuation and risk assessment framework. } \\
\text { Given the potential risk of a prolonged low-interest rate environment with } \\
\text { potentially declining interest rates, transparency on the long-term } \\
\text { financial/economic situation of insurers is particularly important. An ORSA with a } \\
\text { market consistent valuation standard helps to address this potential risk and } \\
\text { would also function as an early warning sign for both the NBB and the industry. }\end{array}$ \\
\hline 17. Capital Adequacy & $\begin{array}{l}\text { We recommend that the NBB, in planning for the early implementation of } \\
\text { certain elements of Solvency II: } \\
\text { a) Explores strengthening both the quantitative and qualitative elements of the } \\
\text { current solvency framework; e.g., ORSA (ICP 16) and conducting quantitative } \\
\text { impact studies with all industry participants; } \\
\text { b) Works with the industry to improve the quality of the calculation of the } \\
\text { Solvency II market consistent balance sheet and capital requirements, over } \\
\text { time; }\end{array}$ \\
\hline
\end{tabular}




\begin{tabular}{|c|c|}
\hline & $\begin{array}{l}\text { c) Enhances the prudential standards for intragroup transactions, including } \\
\text { transactions between insurers and banks within a conglomerate, given the } \\
\text { dominance of insurance groups and conglomerates and the fact the } \\
\text { Solvency I does not incorporate group-risk realistically; } \\
\text { d) Formulates an appropriate stress testing and scenario analysis framework to } \\
\text { facilitate more robust assessment of insurers' risk exposures to compensate } \\
\text { for the lack of risk sensitivity of Solvency I; and } \\
\text { e) Reviews the adequacy of supervisory resources to implement the above } \\
\text { measures and the eventual implementation of Solvency II. }\end{array}$ \\
\hline 18. Intermediaries & $\begin{array}{l}\text { The FSMA's proposal to adapt MiFID } 2 \text { for insurance intermediation will improve } \\
\text { observance of ICP 18. In addition, it is advisable: } \\
\text { a) For the FSMA to review the effectiveness of the current continuous } \\
\text { professional development requirements and establish appropriate } \\
\text { regulatory threshold beyond which intermediaries are expected to } \\
\text { implement sound corporate governance practices; and } \\
\text { b) For the authorities to amend the Intermediation Law to impose a time limit } \\
\text { for the migration of sub-agents to agents/brokers. }\end{array}$ \\
\hline $\begin{array}{l}\text { 19. Conduct of } \\
\text { Business }\end{array}$ & $\begin{array}{l}\text { Strengthen the COB regime by: } \\
\text { a) Implementing the proposed amendments to the Supervision Law and the } \\
\text { MiFID } 2 \text { requirements to better ensure fair treatment of clients; } \\
\text { b) Empowering the FSMA to issue enforceable rules on: the handling of claims } \\
\text { and policy servicing by insurers; and fact-finding of client's needs and } \\
\text { financial circumstances as basis for financial advice; and } \\
\text { c) Ensuring that the FSMA is adequately resourced to supervise the COB of } \\
\text { insurers and intermediaries effectively. }\end{array}$ \\
\hline 20. Public Disclosure & Address the significant gaps in the disclosure requirements identified. \\
\hline $\begin{array}{l}\text { 21. Countering Fraud in } \\
\text { Insurance }\end{array}$ & $\begin{array}{l}\text { Empower the NBB and the FSMA to issue enforceable rules requiring insurers } \\
\text { and intermediaries to report insurance fraud. }\end{array}$ \\
\hline $\begin{array}{l}\text { 22. Anti-Money } \\
\text { Laundering and } \\
\text { Combating the } \\
\text { Financing of Terrorism }\end{array}$ & $\begin{array}{l}\text { Periodically reconsider whether or not nonlife insurance should be covered by } \\
\text { the } \mathrm{AML} / \mathrm{CTF} \text { regime in Belgium. }\end{array}$ \\
\hline $\begin{array}{l}\text { 23. Group-wide } \\
\text { Supervision }\end{array}$ & $\begin{array}{l}\text { The implementation of Solvency II will enhance observance with ICP } 23 . \\
\text { Plan for adequate supervisory resources to supervise insurance groups, } \\
\text { especially the complex cross-border groups that are domestic SIFIs. }\end{array}$ \\
\hline $\begin{array}{l}\text { 24. Cross-border } \\
\text { Cooperation and } \\
\text { Coordination on Crisis } \\
\text { Management }\end{array}$ & $\begin{array}{l}\text { The conclusion of the coordination arrangements and emergency plans will } \\
\text { enable the NBB to implement cross-border cooperation and coordination on } \\
\text { crisis management for insurance groups. The arrangements and plans should } \\
\text { also be regularly tested by all involved supervisors. The authorities are advised to } \\
\text { consider empowering the NBB to require insurers and insurance groups to } \\
\text { establish crisis management plans or contingency plans. }\end{array}$ \\
\hline
\end{tabular}




\section{Authorities' Response to the Assessment}

\section{ICP 1: Objectives, powers and responsibilities of the supervisor}

64. Given its recent implementation the NBB finds it's early to conduct a thorough review of the Twin Peaks structure. However, any potential gaps, duplication or coordination issues will be promptly dealt with when they appear.

65. The NBB agrees that an explicit legal basis or principle based approach would be more comfortable, but the NBB is convinced that article 14bis, $\S 4$ Insurance Law could for some limited prudential issues address such lack of an explicit legal basis.

\section{ICP 2: Supervisor}

66. The NBB agrees that there is an inconsistency between the immediate execution possibility for banking and insurance recovery measures in case of an appeal and will rectify this situation via an amendment of the NBB Organic Law.

67. The NBB will reconsider the adequacy of the supervisory resources in order to achieve the appropriate supervisory intensity and effectiveness in the course of 2013.

\section{ICP 5: Suitability of Persons}

68. The NBB is in the process of revising the fit and proper regulation and is currently holding a public consultation on the new proposal. The adoption of the new regulation is planned in the course of 2013.

\section{ICP 7: Corporate Governance}

69. The NBB agrees with all recommendations on corporate governance and is planning to incorporate these when revising the governance requirements in the second half of 2013.

\section{ICP 9: Supervisory Review and Reporting}

70. The NBB continues the development and refinement of the scorecarding approach which should allow for the establishment of a baseline supervisory program and a more precise estimation of required resources. The NBB is planning to increase its technical capacity in particular areas by recruiting additional staff (e.g. actuaries).

71. The NBB will consider the establishment of internal policies for inspecting outsourced functions when updating the methodology and work plan of the audit team.

72. The NBB will reflect on how the contributions of external auditors and actuaries can be assessed on their effectiveness within the context of their role under Solvency II. In this regard, discussions have been initiated with the professional organizations. 


\section{ICP 14: Valuation}

73. The NBB is currently revising the Flashing Light approach including the exemption file method in order to better monitor the adequacy of technical provisions, in particular for life insurers' legacy portfolios with high guarantees. The revised Flashing Light approach will be implemented in the second half of 2013.

74. Next to this, the NBB will seriously consider the outcome of European Insurance and Occupational Pensions Authority's (EIOPA) decisions to advance the implementation of some parts of the Solvency II framework.

\section{ICP 16: Enterprise Risk Management for Solvency Purposes}

75. The implementation of ORSA is part of the interim guidelines, which are currently prepared by EIOPA to advance the implementation of Solvency II. The NBB will seriously consider the outcome of EIOPA's decisions to advance the implementation of some parts of the Solvency II framework including ORSA.

\section{ICP 17: Capital Adequacy}

76. The NBB is reflecting on different measures to strengthen the solvency framework including an adaptation of the Flashing Light approach, a revision of the profit sharing mechanism and alternative ways to decrease the maximum guaranteed interest rate.

77. The NBB participates in EIOPA working groups to improve the quality of the calculation of the Solvency II market consistent balance sheet and capital requirements. In this regard, the NBB has recently launched an impact assessment to test proposed measures for products with long term guarantees.

78. In order to have a more accurate view on the solvency position and risk exposures of insurers, the NBB is planning to conduct an EIOPA-led stress test in the second half of 2013. The NBB will also continue the execution of periodic vulnerabilities analyses to monitor the evolution of life insurers' legacy portfolios with high guarantees.

\section{ICP 20: Public Disclosure}

79. The NBB is planning to introduce higher disclosure requirements under Solvency II. 